\title{
Glass Formulation Development for INEEL Sodium-Bearing Waste
}

\author{
J. D. Vienna \\ W. C. Buchmiller \\ J. V. Crum \\ D. D. Graham \\ D. S. Kim \\ B. D. MacIsaac \\ M. J. Schweiger \\ Pacific Northwest National Laboratory, Richland, WA 99352 \\ D. K. Peeler \\ T. B. Edwards \\ I. A. Reamer \\ R. J. Workman \\ Westinghouse Savannah River Company, Aiken, SC 29808
}

August 2002

Prepared for the U.S. Department of Energy

under Contract DE-AC06-76RL01830 


\title{
Glass Formulation Development For INEEL Sodium-Bearing Waste
}

\author{
J. D. Vienna \\ W. C. Buchmiller \\ J. V. Crum \\ D. D. Graham \\ D. S. Kim \\ B. D. MacIsaac \\ M. J. Schweiger \\ Pacific Northwest National Laboratory, Richland, WA 99352
}

D.K. Peeler

T.B. Edwards

I.A. Reamer

R.J. Workman

Westinghouse Savannah River Company, Aiken, SC 29808

August 2002

Prepared for the U.S. Department of Energy

under Contract DE-AC06-76RL01830

Pacific Northwest National Laboratory

Richland, Washington 99352 


\begin{abstract}
Studies were performed to develop and test a glass formulation for immobilization of sodium-bearing waste (SBW), which is a high soda, acidic, high-activity waste stored at the Idaho National Engineering and Environmental Laboratory (INEEL) in 10 underground tanks. It was determined in previous studies that SBW's sulfur content dictates its loading in borosilicate glasses to be melted by currently assumed processes. If the sulfur content (which is $\sim 4.5$ mass $\% \mathrm{SO}_{3}$ on a non-volatile oxide basis in $\mathrm{SBW}$ ) of the melter feed is too high, then a molten, alkali-sulfate-containing salt phase accumulates on the melt surface. The avoidance of salt accumulation during the melter process and the maximization of sulfur incorporation into the glass melt were the main focus of this development work. A glass was developed for 20 mass \% SBW (on a non-volatile oxide basis), which contained 0.91 mass\% $\mathrm{SO}_{3}$, that met all the processing and product-quality constraints determined for SBW vitrification at a planned INEEL treatment plant-SBW-22-20. This report summarizes the formulation efforts and presents the data developed on a series of glasses with simulated SBW.
\end{abstract}





\section{Summary}

The U.S. Department of Energy Office of Science and Technology (through the Tanks Focus Area) and the Office of Waste Management (through the Idaho National Engineering and Environmental Laboratory (INEEL) High-Level Waste Program) are sponsoring a joint effort by INEEL, Pacific Northwest National Laboratory, and the Savannah River Technology Center to investigate processes and formulations for vitrifying sodium-bearing waste (SBW). This report evaluates the option of directly vitrifying the SBW stored at INEEL, which would involve either no feed conditioning or at the most minimal conditioning before vitrification. Various other projects have developed technologies for vitrifying waste, but the composition of SBW differs significantly from those wastes, and it is unlikely that additive compositions developed for them could be applied to SBW in a cost-effective manner. SBW is similar to Hanford low-activity waste (LAW), however, making it possible to use the results of development activities for Hanford LAW vitrification to some extent. This report updates the status of the glass-formulation efforts in support of melter demonstrations.

The studies described in this report focused on efforts to develop a flowsheet for vitrifying waste stored in INEEL Tank WM-180. An acceptable glass must meet product properties required for wasteform acceptance and also allow for adequate operation of the melter. Acceptable glass must conform to limitations on the response of glass to the product consistency test, and chemical and phase-stability information must be reported. The glass formulation was developed assuming properties that would be pertinent to processing either in a liquid-fed, Joule-heated, ceramic-lined melter (JHCM) or in a coldcrucible induction melter (CCIM), both of which are considered viable options for treating SBW. The processing constraints are not identical for the two technologies, but the goal was to develop a glass that would work with either technology. Glass compositions for immobilizing SBW waste were formulated based on models that relate glass properties to composition.

A liquid simulant for WM-180 waste was prepared after a series of crucible tests using reagent-grade oxides, carbonates, and boric acid. The objective of these tests was to assess various additive components and their effects on sulfate solubility and glass properties of interest. Based on the batch chemical testing results, only the following 6 of the 17 additive compositions produced glasses that met all of the constraints: SBW-12, $-14,-16,-22,-26$, and -27 (although it should be noted that PCT was not performed on -26 and -27 based glasses).

To gain a better understanding of the effects of glass composition on sulfur partitioning from a slurryfed melter operation, tests were performed to better simulate that process than was allowed by the crucible melts. WM-180 simulant was fabricated, and test experiments were performed. Ramp-heated crucible melt tests were performed to determine the appropriate waste loading (WL), the need for any acid additions or adjustments, and appropriate additive compositions. The centimeter scale melter (CSM) was developed to better simulate those processes that are important to determining the behavior of sulfur in a slurry-fed melter system with batch heating from the glass melt below. No significant difference between the sulfur partitioning was seen in tests with $\mathrm{CaO}$ or $\mathrm{V}_{2} \mathrm{O}_{5}$ or both being removed from the frit or between tests with frit and the hydroxide based feeds. 
Before research-scale melter (RSM) or pilot scale tests, it was desirable to evaluate various additive formulations (or melter feeds) for their potential to form salt layers using the slurry-fed melt-rate furnace (SMRF). The results of SMRF were similar to crucible melts and CSM melts.

The results from the tests presented above suggest that the SBW-22 frit (or additive mix) is appropriate for scale-up tests for the direct vitrification of 2001 WM-180 simulant at 20 mass\% loading. The main focus of formulation work and testing was minimizing the likelihood of salt accumulation and maximizing sulfur retention in the melt. Since these are both strong functions of the chemical and physical processes involved in the melter, it is difficult to extrapolate the results from smaller scale tests performed during this study to the melter. Therefore, it is recommended that the glass be fabricated in scaled melter tests to assure that processability is adequate at a larger scale. 


\section{Glossary}

$\begin{array}{ll}\text { ARM } & \text { Approved Reference Material (ARM-1) } \\ \text { ASTM } & \text { American Society for Testing and Materials } \\ \text { CCC } & \text { centerline canister cooling } \\ \text { CCIM } & \text { cold-crucible induction melter } \\ \text { CETL } & \text { Clemson Environmental Technology Laboratory } \\ \text { CSM } & \text { centimeter scale melter } \\ \text { CVS } & \text { composition variation study } \\ \text { DIW } & \text { deionized water } \\ \text { DOE } & \text { U.S. Department of Energy } \\ \text { DWPF } & \text { Defense Waste Processing Facility } \\ \text { EA } & \text { environmental assessment } \\ \text { GC-MS } & \text { gas chromatography-mass spectrometry } \\ \text { GFC } & \text { glass-forming chemical } \\ \text { HLW } & \text { high-level waste } \\ \text { IC } & \text { ion chromatography } \\ \text { ICP-AES } & \text { inductively coupled plasma-atomic emission spectroscopy } \\ \text { ICP-OES } & \text { inductively coupled plasma-optical emission spectrometry } \\ \text { ICPP } & \text { Idaho Chemical Processing Plant } \\ \text { INEEL } & \text { Idaho National Environmental and Engineering Laboratory } \\ \text { INTEC } & \text { Idaho Nuclear Technology and Engineering Center } \\ \text { JHCM } & \text { Joule-heated, ceramic-lined melter } \\ \text { LAW } & \text { low-activity waste } \\ \text { PCT } & \text { Product Consistency Test } \\ \text { PNNL } & \text { remote-handled transuranic (waste) } \\ \text { RH-scale melter }\end{array}$




$\begin{array}{ll}\text { SMRF } & \text { slurry fed melt rate furnace } \\ \text { SRS } & \text { Savannah River Site } \\ \text { SRTC } & \text { Savannah River Technology Center } \\ \text { T } & \text { temperature } \\ \text { TFA } & \text { Tanks Focus Area } \\ T_{L} & \text { liquidus temperature } \\ \eta & \text { viscosity } \\ \text { WAPS } & \text { Waste Acceptance Product Specification } \\ \text { WIPP } & \text { Waste Isolation Pilot Plant } \\ \text { WL } & \text { waste loading } \\ \text { WSRC } & \text { Westinghouse Savannah River Company } \\ \text { WVDP } & \text { West Valley Demonstration Project } \\ \text { XRD } & \text { X-ray diffraction } \\ \text { XRF } & \text { X-ray fluorescence spectroscopy }\end{array}$




\section{Acknowledgments}

The authors would like to acknowledge Keith Perry, Denny Bickford, Doug Witt, Ron Goles, John Darab, Harry Smith, Jerry Christian, Pavel Hrma, and Darryl Siemer for technical guidance; Alex Cozzi and Harry Smith for their technical reviews; David Best, Eric Frickey, Ron Sanders, May-Lin Thomas, and Sherry Vissage for chemical analyses; Wayne Cosby for masterful and prompt editing; and William Holtzscheiter, Arlin Olson, Lance Laurhaus, and Chris Musick for management and guidance. This study was funded by the Department of Energy Office of Science and Technology through the Tanks Focus Area. Pacific Northwest National Laboratory is operated by Battelle for the U.S. Department of Energy under Contract DE-AC06-76RL01830. 



\section{Contents}

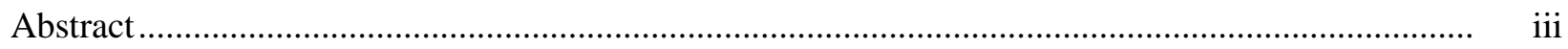

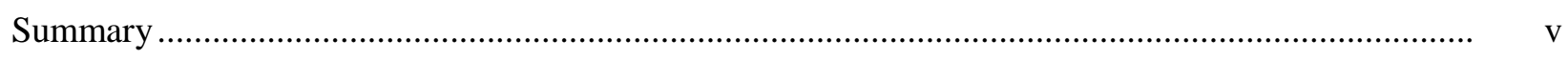

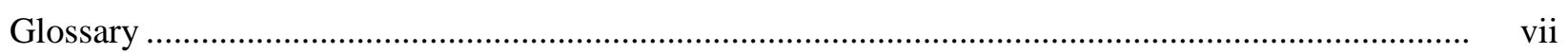

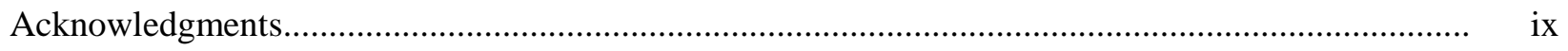

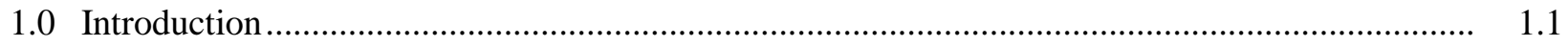

2.0 Waste-Stream Basis for Current Testing ......................................................................... 2.1

3.0 Glass Property/Composition Constraints …................................................................. 3.1

4.0 Functions to Relate Glass Properties to Composition ..........................................................

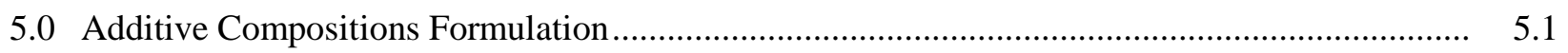

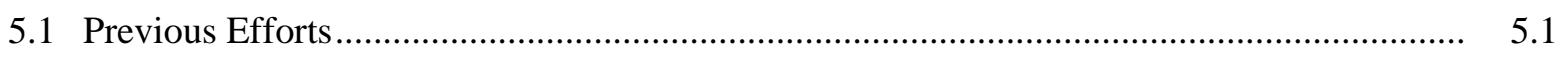

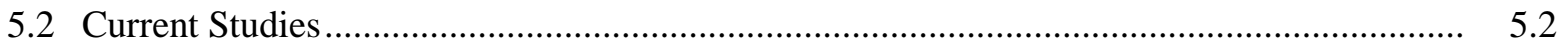

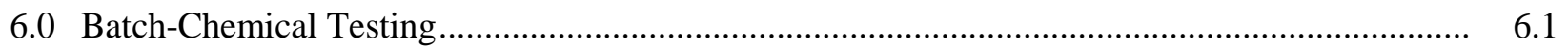

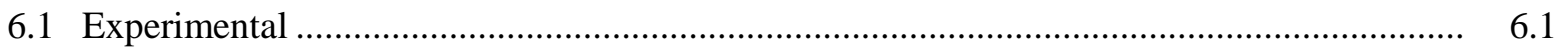

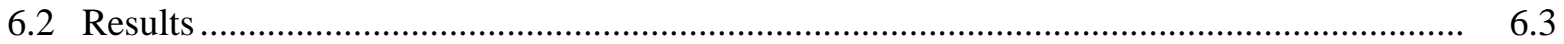

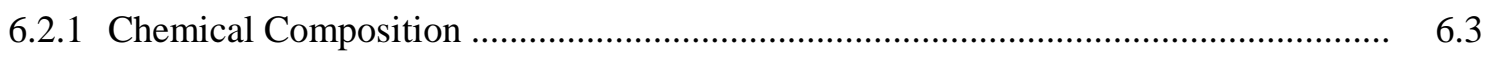

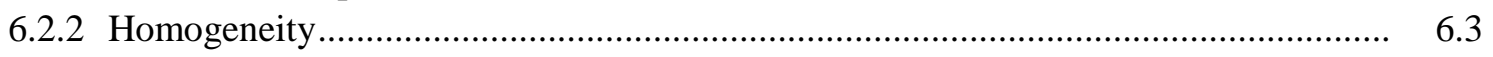

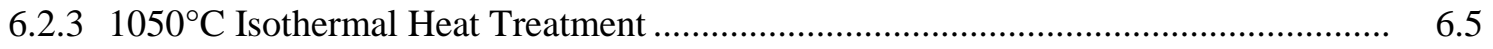

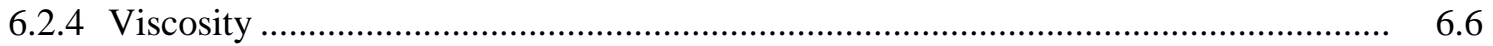

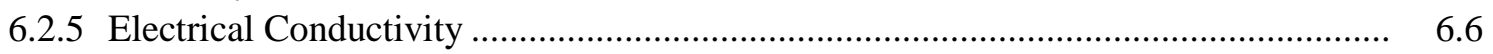

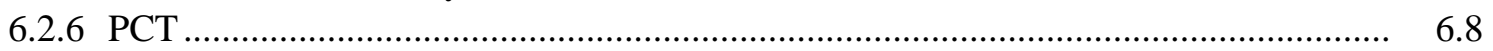

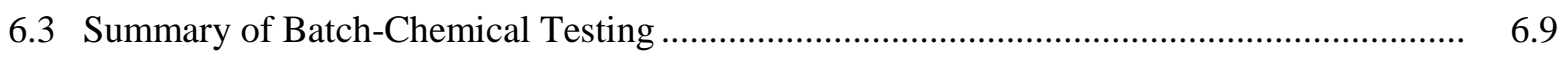

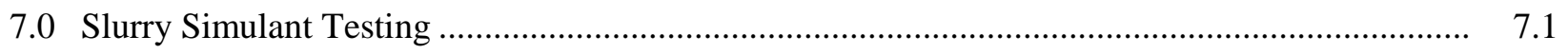

7.1 Fabrication of WM-180 Simulant and Melter Feed .....................................................

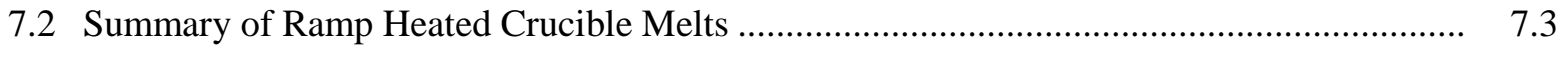

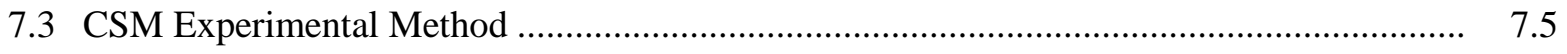




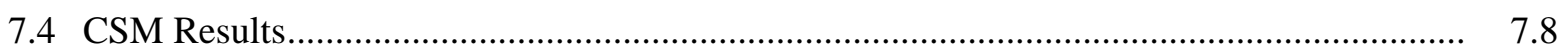

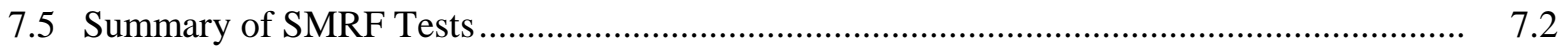

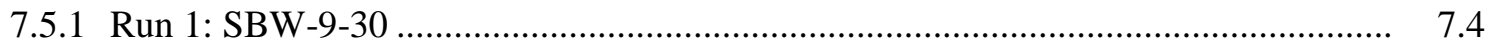

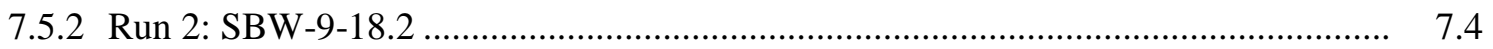

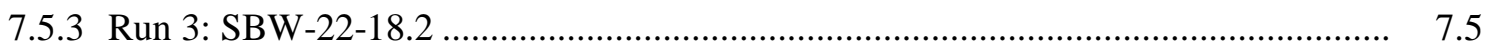

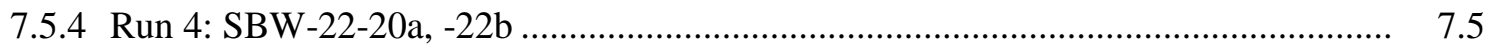

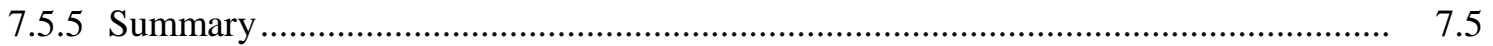

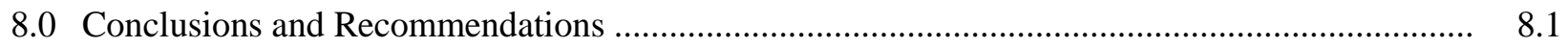

9.0 References

Appendix A: Target vs. Measured Chemical Composition Analysis .............................................. A.1

Appendix B: Visual Observations of SBW Glasses .......................................................... B.1

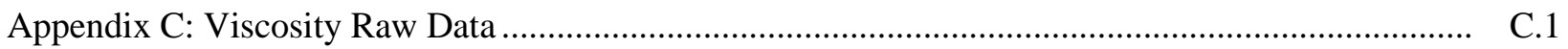

\section{Figures}

6.1. Electrical Conductivity of SBW-22-20 Melt as a Function of Inverse Temperature.................... $\quad 6.7$

6.2. Comparison of ri for Quenched and CCC Glasses............................................................... 6.9

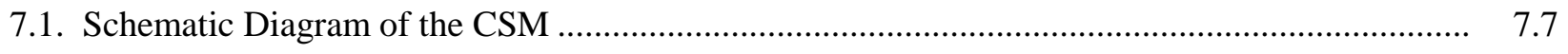

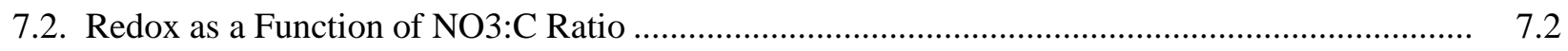

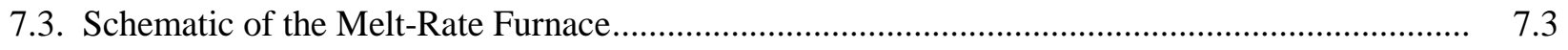

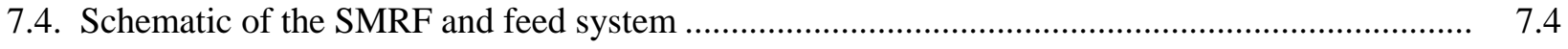

\section{Tables}

2.1. Comparison of SBW Simulant Compositions Used in Formulation and Testing ....................... 2.2

3.1. Constraints Used in SBW Glass Formulation ......................................................................

4.1. Property-Composition Coefficients (ai values) ................................................................. 4.2 
5.1. Compositions and Results from Previously Developed SBW Additive Mixes

(in mass\% Oxides)

5.2. Additive Compositions Tested in This Study

5.3. SBW-11-18.5 Glass Composition (mass\% oxides)

5.4. Predicted Viscosity $\left(\eta_{1150}\right.$ in Pa.s) and $r_{i}$ values (in $\left.\mathrm{g} / \mathrm{m}^{2}\right)$ for Glasses Formulated with 18.5 mass\% $2001 \mathrm{WM}-180$ Simulant Using $\mathrm{a}_{\mathrm{i}}$ Values from Table 4.1.

5.5. Predicted Viscosity $\left(\eta_{1150}\right.$ in Pa.s $)$ and $r_{i}$ Values (in $\mathrm{g} / \mathrm{m}^{2}$ ) for Glasses Formulated with Various Loadings of 2001 WM-180 Simulant Using $a_{i}$ Values from Table 4.1 and for Comparison, the ai Values from Hrma et al. (1994).

6.1. Centerline Canister Cooling Schedule Utilized.

6.2. Visual Observations of Homogeneity for Quenched and CCC SBW Glasses.

6.3. Comparison of Target and Measured SO3 Concentrations.

6.4. Visual Observations of Homogeneity for Quenched and CCC SBW Glasses...

6.5. Calculated Viscosity at $1150 \square \mathrm{C}\left(\square 1150^{\circ} \mathrm{C}\right)$ for Select Glasses Based on the VogelTamman-Fulcher Fit of the Measured Data.....

6.6. Electrical Conductivity Data for SBW-22-20 Glass Melt.

6.7. Normalized B, Li, Na, and Si Releases (g/m2) from PCT of Quenched and CCC SBW Glasses Samples

7.1. Chemicals Used in the Preparation of 2001 WM-180 Simulant

7.2. Chemical Analysis of SBW Simulant.

7.3. Chemical Sources for Glass-Forming Additives..............................................................

7.4. Parameters, Visual Observations, and Results for the Liquid Simulant Crucible Tests ............... $\quad 7.4$

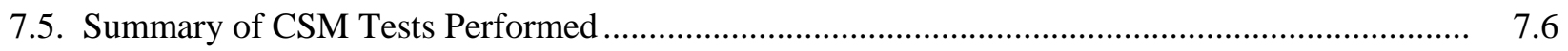

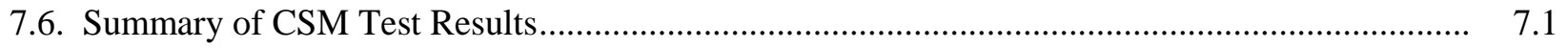

7.7. Summary of Glass Redox and Sugar/NO3 Concentrations .................................................

7.8. Summary of SMRF Test Runs with SBW Simulants .............................................................

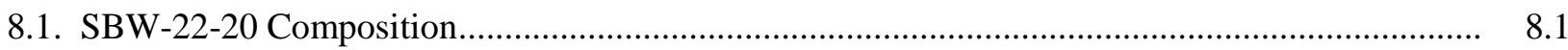




\subsection{Introduction}

For about four decades (beginning in the early 1960s), radioactive wastes have been collected and calcined from nuclear-fuels reprocessing at the Idaho Nuclear Technology and Engineering Center (INTEC), formerly Idaho Chemical Processing Plant (ICPP). ${ }^{\text {(a) }}$ Over this time span, secondary radioactive wastes have also been collected and stored as liquid from reprocessing, decontamination, laboratory, and fuel-storage activities. These liquid wastes are collectively called sodium-bearing wastes (SBW). About 3.8 M L (1 M gal) of these wastes are temporarily stored in stainless steel tanks at the Idaho National Engineering and Environmental Laboratory (INEEL). These liquid SBWs may be vitrified and sent to the federal geologic repository or the Waste Isolation Pilot Plant (WIPP) for final disposal.

The Batt Settlement Agreement was established in August 1995 between the U.S. Navy, the State of Idaho, and the U.S. Department of Energy (DOE 1995). One of the requirements per this agreement is to remove liquid wastes (i.e., SBW) from and cease the use of the INEEL liquid waste storage tanks by the end of 2012. More immediately, technology must be developed to provide information required to initiate the design of the SBW treatment facility in the year 2002. Direct vitrification (no or minimal feed conditioning before vitrification) is being considered as a possible immobilization process for SBW, which is the focus of this report. ${ }^{(b)}$

Vitrification is considered the "Best Demonstrated Available Technology" for immobilizing highlevel waste (HLW). Precedents for vitrifying INTEC HLW into borosilicate glass have been established by the production-scale operation of the Defense Waste Processing Facility (DWPF) at the Savannah River Site (SRS), the West Valley Demonstration Project (WVDP) at West Valley, New York, and certain European facilities. Production-scale technologies exist for the waste chemistries at these plants. However, it is unlikely that the additive (or frit) formulations developed for immobilizing waste compositions at these sites could be applied to the SBW in a cost-effective manner. The composition of SBW differs significantly from those wastes being vitrified at the DWPF and the WVDP. However, there are similarities between the compositions of SBW and Hanford's low-activity waste (LAW). Therefore, efforts are underway at INEEL to develop integrated flowsheets and identify glass-composition regions for vitrifying SBW while utilizing the results of development activities for Hanford LAW vitrification to the extent possible.

The U.S. Department of Energy (DOE) Office of Science and Technology (through the Tanks Focus Area [TFA]) and the Office of Waste Management (through the INEEL High-Level Waste Program) are sponsoring a joint effort by INEEL, Pacific Northwest National Laboratory (PNNL), and the Savannah River Technology Center (SRTC) to investigate processes and formulations for vitrifying SBW. The overall strategy of this integrated task includes developing glass-property data and glasscomposition/property models that cover the composition region expected from individual and/or blended SBWs. The strategy, in terms of glass-formulation activities, has focused on two primary tasks:

(a) The Idaho National Engineering and Environmental Laboratory, located in Eastern Idaho, consists of an 890-square-mile reservation located 32 miles west of Idaho Falls, Idaho.

(b) Subsequent to the completion of this work, INEEL's Environmental Impact Statement indicated that vitrification of SBW would not be pursued. Alternatives or options being considered include: calcination; steam reforming; cesium ion exchange; and direct evaporation. 
1) collaborative (phased) glass composition variation studies (CVS) that "bound" the composition regions of interest to proposed direct-vitrification flowsheets and 2) preliminary glass-formulation development aimed at specific waste streams to perform melter tests to demonstrate feasibility and collect data required for plant design. Both tasks are focused on providing data required to establish a baseline flowsheet for SBW vitrification.

Edwards et al. (2001) and Scholes et al. (2002) described the SBW CVS design and results. Previous glass-formulation efforts for SBW were reported by Vienna et al. (1999) and Peeler et al. (2001). The results of melter tests using SBW were reported by Goles et al. (2001) and Perry et al. (2001). Preliminary results to identify the parameters influencing sulfur partitioning between the glass melt, offgas, and a molten salt phase were summarized by Darab et al. (2001), with more in-depth analyses reported by Vienna et al. (2002). The results from radioactive tests with WM-180 tank samples were reported by Olson et al. (2001). This report gives an updated status of the glass-formulation efforts in support of melter demonstrations. 


\subsection{Waste-Stream Basis for Current Testing}

The INEEL SBW is stored in 10 tanks with one spare. These wastes will be consolidated into four tanks (WM-180, -188, -189, and -187) before treatment. In early 1999, INTEC supplied an estimate of the blended SBW composition. ${ }^{\text {(a) }}$ Table 2.1 shows this 1998 SBW composition, which was used in the formulation work of Vienna et al. (1999). The focus of further studies was changed to the waste found in Tank WM-180. This tank was scheduled for processing first, and the content was not to be changed by the consolidation of wastes into WM-188 and -189. The initial composition of WM-180, supplied by INTEC $^{(\text {b) }}$ and listed in Table 2.1 as 2000 WM-180, was the focus of the formulation work of Peeler et al. (2001). The composition of WM-180 was updated with new tank-characterization data. Christian (2001) reports the 2001 WM-180 composition (shown in Table 2.1), which like the previous WM-180 composition contains a small fraction of undissolved solids. Comparing these waste compositions, the most substantial difference (with reference to waste vitrification) is in the concentration of $\mathrm{SO}_{3}$. The concentration of $\mathrm{SO}_{3}$ increases from 3.57 to 4.55 mass\% when changing from $2000 \mathrm{WM}-180$ to 2001 WM-180. Since previous formulation studies with WM-180 have shown that the loading of SBW in alkali-borosilicate waste glasses was limited by the allowable sulfur content, this $\sim 20 \%$ increase in sulfur content will likely result in a decrease in waste loading (WL).

(a) C. A. Musick e-mail to J.D. Vienna (PNNL), D. F. Bickford (SRTC), C. M. Jantzen (SRTC), and D. K. Peeler (SRTC); dated January 19, 1999; Subject, "Direct Vitrification for SBW Composition," Idaho National Engineering and Environmental Laboratory, Idaho Falls, Idaho.

(b) J. D. Christian e-mail to T.A. Batcheller, T.G. Garn, D.L. Griffith, R.R. Kimmitt, J.A. McCray, A.L. Olson, D.K. Peeler, D.D. Siemer, N.R. Soelberg, and J.D. Vienna, dated November 6, 2000, Subject: WM-180 Simulant. 
Table 2.1. Comparison of SBW Simulant Compositions Used in Formulation and Testing

\begin{tabular}{|c|c|c|c|}
\hline Component & 1998 SBW & 2000 WM-180 & 2001 WM-180 \\
\hline \multicolumn{4}{|c|}{ Oxides (mass\% non-volatile oxides) } \\
\hline $\mathrm{Al}_{2} \mathrm{O}_{3}$ & 27.34 & 27.96 & 27.52 \\
\hline $\mathrm{As}_{2} \mathrm{O}_{3}$ & 0 & 0 & 0.04 \\
\hline $\mathrm{B}_{2} \mathrm{O}_{3}$ & 0.65 & 0.35 & 0.35 \\
\hline $\mathrm{BaO}$ & 0 & 0.01 & 0.01 \\
\hline $\mathrm{CaO}$ & 2.23 & 2.22 & 2.15 \\
\hline $\mathrm{CdO}$ & 0 & 0.08 & 0.08 \\
\hline $\mathrm{Ce}_{2} \mathrm{O}_{3}$ & 0 & 0.01 & 0.01 \\
\hline $\mathrm{CoO}$ & 0 & 0.21 & 0 \\
\hline $\mathrm{Cr}_{2} \mathrm{O}_{3}$ & 0.25 & 0 & 0.21 \\
\hline $\mathrm{CuO}$ & 0 & 0.05 & 0.05 \\
\hline $\mathrm{Fe}_{2} \mathrm{O}_{3}$ & 1.55 & 1.43 & 1.41 \\
\hline $\mathrm{Gd}_{2} \mathrm{O}_{3}$ & 0 & 0.03 & 0.03 \\
\hline $\mathrm{K}_{2} \mathrm{O}$ & 7.92 & 7.62 & 7.53 \\
\hline $\mathrm{MgO}$ & 0.05 & 0.4 & 0.39 \\
\hline $\mathrm{MnO}$ & 0.78 & 0.82 & 0.81 \\
\hline $\mathrm{MoO}_{3}$ & 0.13 & 0.02 & 0.02 \\
\hline $\mathrm{Na}_{2} \mathrm{O}$ & 50.05 & 52.54 & 51.91 \\
\hline $\mathrm{NiO}$ & 0.55 & 0.09 & 0.09 \\
\hline $\mathrm{P}_{2} \mathrm{O}_{5}$ & 1.19 & 0.8 & 0.79 \\
\hline $\mathrm{PbO}$ & 0.31 & 0.24 & 0.24 \\
\hline $\mathrm{RuO}_{2}$ & 0.04 & 0.01 & 0.01 \\
\hline $\mathrm{SO}_{3}$ & 3.73 & 3.57 & 4.55 \\
\hline $\mathrm{Sb}_{2} \mathrm{O}_{5}$ & 0 & 0 & 0.01 \\
\hline $\mathrm{SeO}_{2}$ & 0 & 0 & 0.01 \\
\hline $\mathrm{SiO}_{2}$ & 0.18 & 0 & 0 \\
\hline $\mathrm{SnO}$ & 0.02 & 0 & 0 \\
\hline $\mathrm{SrO}$ & 0 & 0 & 0.01 \\
\hline $\mathrm{V}_{2} \mathrm{O}_{5}$ & 0 & 0 & 0.07 \\
\hline $\mathrm{ZnO}$ & 0 & 0.07 & 0.07 \\
\hline $\mathrm{ZrO}_{2}$ & 1 & 0.01 & 0.01 \\
\hline \multicolumn{4}{|c|}{ Halogens (mass\% of non-volatile oxides) } \\
\hline $\mathrm{Cl}$ & 1.04 & 0.88 & 0.87 \\
\hline F & 0.98 & 0.57 & 0.73 \\
\hline I & 0.02 & 0.01 & 0.01 \\
\hline \multicolumn{4}{|c|}{ Volatiles (moles/L) } \\
\hline $\mathrm{H}^{+}$ & 1.94 & 1.08 & 1.01 \\
\hline $\mathrm{NO}_{3}^{-}$ & 6.96 & 5.11 & 5.27 \\
\hline \multicolumn{4}{|c|}{ Oxide and Halogen Loading $(g / L)$} \\
\hline Solids & 145.26 & 114.55 & 122.62 \\
\hline
\end{tabular}




\subsection{Glass Property/Composition Constraints}

With the goal of developing an acceptable glass to demonstrate the direct vitrification of INEEL SBW, we must first establish a definition of an acceptable glass. Two types of glass-property limitations must be considered: 1) those product properties required for waste-form acceptance and 2) those processing properties required to allow for adequate melter processability. The product-property requirements for acceptance in the federal repository are dictated by the Waste Acceptance Product Specification (WAPS) (DOE 1996). The WAPS imposes limitations on the response of glass to the product consistency test (PCT) (ASTM 1998) and requires that chemical and phase-stability information be reported. The specific limit set on the PCT response is that the releases of boron, sodium, and lithium, normalized to glass composition, must be significantly less than those of the DWPF Environmental Assessment (EA) glass. The normalized releases of boron $\left(r_{B}\right)$, sodium $\left(r_{N a}\right)$, and lithium $\left(r_{L i}\right)$ for the DWPF-EA glass are $8.35 \mathrm{~g} / \mathrm{m}^{2}, 6.67 \mathrm{~g} / \mathrm{m}^{2}$, and $4.78 \mathrm{~g} / \mathrm{m}^{2}$, respectively (Jantzen et al. 1993). For the purposes of this study, we took a conservative upper release limit of $1 \mathrm{~g} / \mathrm{m}^{2}$ for $r_{B}, r_{N a}$, and $r_{L i}$ to account for uncertainty in the PCT measurement and/or glass composition in the proposed INEEL vitrification plant. This limit is consistent with that used by Vienna et al. (1999) and Peeler et al. (2001).

However, glasses with predicted $r_{B}, r_{N a}$, or $r_{L i}$ higher than $1 \mathrm{~g} / \mathrm{m}^{2}$ were also tested in this study to obtain information on the compositional effects that may help to increase sulfate incorporation in glass (see Section 4.0 for property predictions basis). There currently are no set acceptance criteria for remotehandled transuranic waste (RH-TRU) at WIPP. We have assumed that glasses capable of meeting these conservative PCT response requirements will also meet the eventual acceptance criteria for RH-TRU. An additional product-property-related restriction placed on glass compositions in this study relates to the formation of secondary phases during cooling, which may detract from the durability of glass. Specifically, glasses formed from wastes high in $\mathrm{Na}$ and $\mathrm{Al}$ are susceptible to nepheline crystallization during cooling, which has been shown to increase the normalized releases of some glasses subjected to the PCT ( $\mathrm{Li}$ et al. 1997; $\mathrm{Li}$ et al. 1998). Li et al. (1997) showed that glasses with $\mathrm{Na}_{2} \mathrm{O} \cdot \mathrm{Al}_{2} \mathrm{O}_{3} \cdot \mathrm{SiO}_{2}$ submixtures within the nepheline primary phase field in that ternary mixture are susceptible to nepheline formation. For practical purposes, glasses with $\left[\mathrm{SiO}_{2}\right] /\left(\left[\mathrm{Na}_{2} \mathrm{O}\right]+\left[\mathrm{Al}_{2} \mathrm{O}_{3}\right]+\left[\mathrm{SiO}_{2}\right]\right) \geq 0.62$ are less susceptible to nepheline formation.

The processing-related properties used to develop the glass formulation include those assumed to be pertinent to processing in a liquid-fed, Joule-heated, ceramic-lined melter (JHCM) and in a cold-crucible induction melter (CCIM). Both of these technologies are considered viable options for treating SBW. Generally, the processing criteria for either technology option depend on the plant design, which in turn depends on the glass properties. In addition, the processing criteria for the two technology options may not overlap. Since the melter technology and hence processing-related properties have not been selected and/or are not clearly defined, we will estimate them from operating plants with similar technologies and compare them.

We let the HLW vitrification experience at the DWPF and WVDP be our guide for processing constraints for the JHCM. For these HLW vitrification plants, the nominal melter operating temperature is maintained at or close to $1150^{\circ} \mathrm{C}$. The viscosity $(\eta)$ at the operating temperature is maintained between 2 and $10 \mathrm{~Pa} \cdot \mathrm{s}$. Finally, the liquidus temperature $\left(T_{L}\right)$ of glass in the melter is maintained at least $100^{\circ} \mathrm{C}$ below the operating temperature (i.e., $T_{L}$ nominally $\leq 1050^{\circ} \mathrm{C}$ ). The electrical conductivity of the melt 
was restricted to between 10 and $100 \mathrm{~S} / \mathrm{m}$ at a nominal $100 \mathrm{~Hz}$ and at melt temperature. Two additional processing concerns related to corrosion and sulfur partitioning were used to guide glass-formulation efforts. The accumulation of a salt layer on the melter surface was deemed unacceptable for this study. However, it should be mentioned that relying solely on the sole use of laboratory-scale tests to predict the accumulation of a salt layer during actual melter processing adds risk. In addition, it is assumed, for the purposes of glass formulation, that any sulfur partitioned to the off-gas system would be recycled back to the melter. No specific constraint was used to avoid melts that are excessively corrosive to melter construction material other than the lower $\eta$ constraint.

We let the waste-vitrification experiences in France and Russia be our guide for processing constraints for the CCIM. For this melter technology, there is not a nominal melter operating temperature limit as the glass contact material is not susceptible to corrosion. However, at high temperatures, the volatility from the glass melt can be excessive for high-alkali waste glasses, and at excessively low temperatures, the feed-to-glass process rates are low. Based on the process temperatures used in waste immobilization by CCIM, we will consider the acceptable processing range to be between 1100 and $1400^{\circ} \mathrm{C}$ and determine if this criterion is restrictive (if necessary, changes will be made). The process viscosity can be easily adjusted through temperature by altering the melter power input. The nominal operating viscosity was assumed to be between 5 and $10 \mathrm{~Pa} \cdot \mathrm{s}$. The electrical conductivity of glass was restricted to between 10 and $100 \mathrm{~S} / \mathrm{m}$ at the nominal melter operating temperature and a frequency $>1$ $\mathrm{kHz} .{ }^{\text {(a) }}$ With a bottom drain configuration, operated in semi-batch mode, the CCIM is expected to tolerate a larger fraction of solid phase than in the standard DWPF- or WVDP-designed JHCMs. Therefore, in place of a $T_{L}$ restriction, a volume fraction of crystalline phase in equilibrium with the melt will be restricted to $\leq 3 \mathrm{vol} \%$. As with the JHCM constraints, the accumulation of a salt layer on the melter surface was deemed unacceptable for this study. As previously mentioned, using only laboratory-scale tests to predict the accumulation of a salt layer during actual melter processing adds risk. In addition, it is assumed for the purposes of glass formulation that any sulfur lost to the off-gas system would be recycled back to the melter. No specific constraints on the power absorption or the related properties of skull stability were used.

Table 3.1 summarizes the glass-property and composition constraints used to develop a glass to demonstrate the SBW (WM-180) vitrification flowsheet. Although these constraints define the criteria for glass acceptability, glasses outside these constraints were fabricated and tested to better understand the process of salt segregation from high-sulfur waste-glass melts and the impacts of compositional variation on sulfur partitioning and other glass properties of interest.

As discussed earlier, the processing constraints for the JHCM and CCIM are not identical. Our objective is to develop a glass that will be useful for demonstrating the processing of SBW vitrification by either technology. The formulation work will be performed toward a single set of constraints that will likely yield a non-ideal, but acceptable, glass for both technologies. There is an overlap in the $T_{M}$ constraint between the two technologies; the $T_{M}$ constraint used in formulation is $T_{M} \leq 1150^{\circ} \mathrm{C}$. This value represents what is thought to be nearly ideal for the JHCM with Inconel ${ }^{\circledR}$ electrodes. However, for hightemperature melters such as CCIM, the ideal $T_{M}$ is significantly higher. There is also an overlap in $\eta_{M}$ constraints between 5 and $10 \mathrm{~Pa} \cdot \mathrm{s}$. This overlapping range is used as the constraint. An $\eta_{M}$ between 3 and $5 \mathrm{~Pa} \cdot \mathrm{s}$ is thought to be ideal for the WVDP- and DWPF-type JHCMs. Initial formulation work found

(a) The electrical conductivity is assumed to be independent of frequency at frequencies $\geq 1 \mathrm{kHz}$. 
that the $T_{L}$ constraint and quenched glass homogeneity did not limit the loading of SBW or greatly affect the composition of the resulting glass. Therefore, the more restrictive of these constraints (both for $\mathrm{JHCM}$ ) were retained for the purposes of formulation. All other constraints were the same.

Table 3.1. Constraints Used in SBW Glass Formulation

\begin{tabular}{|c|c|c|}
\hline Property & JHCM & $\overline{\text { CCIM }}$ \\
\hline Nominal operating temperature $\left(T_{M}\right)$ & $T_{M} \leq 1150^{\circ} \mathrm{C}$ & $1100 \leq T_{M} \leq 1400$ \\
\hline Viscosity at $T_{M}\left(\eta_{M}\right)$ & $2<\eta_{M}<10 \mathrm{~Pa} \cdot \mathrm{s}$ & $5<\eta_{M}<10 \mathrm{~Pa} \cdot \mathrm{s}$ \\
\hline Electrical conductivity at $T_{M}\left(\varepsilon_{M}\right)$ & $10<\varepsilon_{M}<100 \mathrm{~S} / \mathrm{m}$ & $10<\varepsilon_{M}<100 \mathrm{~S} / \mathrm{m}$ \\
\hline Liquidus temperature $\left(T_{L}\right)$ & $T_{L} \leq 1050^{\circ} \mathrm{C}$ & -- \\
\hline$\left[\mathrm{SiO}_{2}\right] /\left(\left[\mathrm{SiO}_{2}\right]+\left[\mathrm{Na}_{2} \mathrm{O}\right]+\left[\mathrm{Al}_{2} \mathrm{O}_{3}\right]\right)$ & $\geq 0.62$ & $\geq 0.62$ \\
\hline $\begin{array}{l}\text { Normalized PCT boron release }\left(r_{B}\right) \\
\text { (both quenched and CCC samples) }\end{array}$ & $r_{B}<1 \mathrm{~g} / \mathrm{m}^{2}$ & $r_{B}<1 \mathrm{~g} / \mathrm{m}^{2}$ \\
\hline $\begin{array}{c}\text { Normalized PCT sodium release }\left(r_{N a}\right) \\
\text { (both quenched and CCC samples) }\end{array}$ & $r_{N a}<1 \mathrm{~g} / \mathrm{m}^{2}$ & $r_{N a}<1 \mathrm{~g} / \mathrm{m}^{2}$ \\
\hline $\begin{array}{l}\text { Normalized PCT lithium release }\left(r_{L i}\right) \\
\text { (both quenched and CCC samples) }\end{array}$ & $r_{L i}<1 \mathrm{~g} / \mathrm{m}^{2}$ & $r_{L i}<1 \mathrm{~g} / \mathrm{m}^{2}$ \\
\hline Salt Layer Accumulation & Unacceptable & Unacceptable \\
\hline Quenched Glass Homogeneity $\left(\mathrm{H}_{\mathrm{Q}}\right)$ & Homogeneous $^{(\mathrm{a})}$ & $\leq 3$ vol. $\%$ \\
\hline CCC Glass Homogeneity $\left(\mathrm{H}_{\mathrm{C}}\right)$ & $\begin{array}{c}<5 \text { vol. } \% \\
\text { secondary phase }\end{array}$ & $\begin{array}{c}<5 \text { vol. } \% \\
\text { secondary phase }\end{array}$ \\
\hline \multicolumn{3}{|c|}{$\begin{array}{l}\text { (a) Homogeneity was judged by the lack of second-phase identification by } \\
\text { X-ray diffraction (XRD) and by optical microscopy at magnifications of } \\
\geq 100 \times \text {. }\end{array}$} \\
\hline
\end{tabular}




\subsection{Functions to Relate Glass Properties to Composition}

Glass compositions for immobilizing SBW waste can be formulated based on models that relate glass properties to composition. This approach was successfully used by Vienna et al. (1999) in the development of SBW-1 and by Peeler et al. (2001) in the development of SBW-9; thus, it provides the starting point for glass-formulation activities using the latest WM-180 composition and constraints. To calculate a glass composition for SBW waste that meets the criteria listed in Table 3.1, we first must describe the glass properties as functions of composition or waste and additive concentrations. For the purposes of these scoping tests, selected glass properties were empirically modeled as linear functions of composition:

$$
P=\sum_{i=1}^{n} a_{i} x_{i}
$$

where

$$
\begin{aligned}
P & =\text { transformed property } \\
a_{i} & =\mathrm{i}^{\text {th }} \text { component coefficient } \\
x_{i} & =\mathrm{i}^{\text {th }} \text { component mole fraction in glass } \\
\mathrm{n} & \left.=\text { number of components in glass (thus } \Sigma x_{i}=1\right) .{ }^{\text {(a) }}
\end{aligned}
$$

Here, the normalized mole fraction of the $\mathrm{n}$ components should be used for $x_{i}$. This corresponds to the assumption that the glass properties depend only on the relative proportions (mole fractions) of the $\mathrm{n}$ components that have $a_{i}$ values. Table 4.1 lists the $a_{i}$ values used to model glass properties in this study, which are from Hrma et al. (2001). The viscosity model used the Arrhenius form

$$
\ln (\eta)=A+\frac{B}{T}
$$

where $A$ and $B$ are constants, and $T$ is the absolute temperature. The constants $A$ and $B$ are modeled using Equation (4.1), and viscosity is calculated as a function of temperature from Equation (4.2).

The first-order approximations for the properties listed in Table 4.1 provide a good foundation for initial glass-formulation efforts. However, two significant shortcomings must be pointed out: 1) the use of these approximations is recommended only within the composition region covered by the experimental data used to fit component coefficients (i.e., the $a_{i}$ values) and 2) no data set sufficient to model $T_{L}, \mathrm{H}_{\mathrm{Q}}$, $\mathrm{H}_{\mathrm{C}}$, melter corrosion, or salt formation related properties was found for this specific composition range. Experimental data on salt formation, $T_{L}, \mathrm{H}_{\mathrm{Q}}$, and $\mathrm{H}_{\mathrm{C}}$ were generated on glasses with systematically varied composition that meet or exceed the requirements for those properties for which models exist.

(a) See Hrma et al. (1994) for details on this type of property model. 
Table 4.1. Property-Composition Coefficients ( $a_{i}$ values)

\begin{tabular}{|c|c|c|c|c|c|}
\hline \multirow[b]{2}{*}{ Oxide } & \multicolumn{2}{|c|}{ 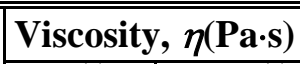 } & \multicolumn{3}{|c|}{ Normalized Release, $r_{i}$ in $\mathrm{g} / \mathrm{m}^{2}$} \\
\hline & $\mathbf{A}^{(\mathbf{a})}$ & $\mathbf{B}(\mathbf{K})^{(\mathbf{a})}$ & $\ln \left(r_{B}\right)$ & $\ln \left(r_{L i}\right)$ & $\ln \left(r_{N a}\right)$ \\
\hline $\mathrm{Al}_{2} \mathrm{O}_{3}$ & -2.860 & 27599 & -32.132 & -29.331 & -32.858 \\
\hline $\mathrm{B}_{2} \mathrm{O}_{3}$ & -13.594 & 8765 & 14.509 & 11.958 & 9.957 \\
\hline $\mathrm{CaO}$ & -25.804 & 27511 & -12.976 & -9.121 & -4.018 \\
\hline $\mathrm{Fe}_{2} \mathrm{O}_{3}$ & -3.490 & -835 & -6.74 & -9.463 & -9.11 \\
\hline $\mathrm{K}_{2} \mathrm{O}$ & -16.589 & 14436 & -10.312 & -6.515 & 0.323 \\
\hline $\mathrm{Li}_{2} \mathrm{O}$ & -7.100 & -10377 & 9.558 & 9.507 & 7.328 \\
\hline $\mathrm{MgO}$ & -19.102 & 25120 & 0.399 & -0.484 & 2.575 \\
\hline $\mathrm{MnO}_{\mathrm{x}}$ & & & -18.462 & -14.389 & -16.326 \\
\hline $\mathrm{Na}_{2} \mathrm{O}$ & -9.974 & 632 & 16.821 & 13.193 & 18.873 \\
\hline $\mathrm{P}_{2} \mathrm{O}_{5}$ & & & -36.1 & -28.686 & -36.605 \\
\hline $\mathrm{SiO}_{2}$ & -10.136 & 26427 & -4.41 & -3.605 & -4.278 \\
\hline $\mathrm{ZrO}_{2}$ & -55.621 & 95153 & -14.976 & -13.177 & -18.384 \\
\hline $\mathrm{Ln}_{2} \mathrm{O}_{3}{ }^{(\mathrm{e})}$ & 43.460 & -78677 & & & \\
\hline $\mathrm{F}$ & -83.850 & 108852 & & & \\
\hline \multicolumn{6}{|c|}{ (a) $\mathrm{A}$ and $\mathrm{B}$ are $\eta$ parameters } \\
\hline
\end{tabular}




\subsection{Additive Compositions Formulation}

This section describes previous efforts at formulating additive compositions as well as current studies. Seventeen additive compositions were fabricated for the current effort.

\subsection{Previous Efforts}

Ten additive compositions were previously developed for SBW vitrification (Vienna et al. 1999; Peeler et al. 2001). The compositions for these additive compositions, SBW-1 to -10, reported earlier, are listed in Table 5.1. SBW-1 was developed to demonstrate 1998 SBW simulant vitrification in the Envitco EV-16 melter at Clemson Environmental Technologies Laboratory (CETL) (Vienna et al. 1999). The objectives for this formulation were to develop a glass with acceptable process and product-qualityrelated properties without any salt-formation restrictions. The composition of 65 mass $\%$ of the SBW-1 additives and $35 \%$ of the 1998 SBW simulant was successfully processed in the EV-16 without any detectable salt formation. However, due to a misbatch in the melter feed, the nominal target $\mathrm{SO}_{3}$ in the feed was only 1.07 mass $\%$ rather than the designed value of 1.35 mass $\%$. These results are summarized by Darab et al. (2001) and again by Vienna et al. (2002).

Table 5.1. Compositions and Results from Previously Developed SBW Additive Mixes (in mass\% Oxides)

\begin{tabular}{||l|c|c|c|c|c|c|c|c|c|c||}
\hline & SBW-1 & SBW-2 & SBW-3 & SBW-4 & SBW-5 & SBW-6 & SBW-7 & SBW-8 & SBW-9 & SBW-10 \\
\hline $\mathrm{B}_{2} \mathrm{O}_{3}$ & 14.26 & 12.00 & 15.00 & 12.00 & 15.00 & 15.00 & 10.00 & 15.00 & 15.00 & 12.00 \\
\hline $\mathrm{BaO}$ & --- & --- & --- & --- & --- & --- & --- & --- & --- & 2.00 \\
\hline $\mathrm{CaO}$ & --- & --- & --- & 2.00 & 4.00 & 2.00 & 4.00 & 2.00 & 5.00 & --- \\
\hline $\mathrm{Fe}_{2} \mathrm{O}_{3}$ & 11.31 & 11.31 & 11.31 & 12.00 & 12.00 & 12.00 & 15.00 & 15.00 & 10.00 & 12.00 \\
\hline $\mathrm{Li}_{2} \mathrm{O}$ & 2.67 & 4.00 & 4.50 & 4.00 & 4.00 & 4.00 & 5.00 & 5.00 & 5.00 & 4.00 \\
\hline $\mathrm{SiO}_{2}$ & 68.69 & 69.61 & 66.11 & 70.00 & 65.00 & 67.00 & 66.00 & 63.00 & 65.00 & 70.00 \\
\hline $\mathrm{TiO}_{2}$ & 3.08 & 3.08 & 3.08 & --- & --- & --- & -- & --- & --- & --- \\
\hline
\end{tabular}

The formulation for SBW-2 was an adjustment of SBW-1 to allow for the development of an acceptable glass with $2000 \mathrm{WM}-180$ concentrations between 22 and 35 mass\% (equivalent to 0.8 to 1.25 mass $\% \mathrm{SO}_{3}$ in the glass). The concentrations of $\mathrm{B}_{2} \mathrm{O}_{3}, \mathrm{BaO}, \mathrm{CaO}, \mathrm{Fe}_{2} \mathrm{O}_{3}, \mathrm{Li}_{2} \mathrm{O}, \mathrm{SiO}_{2}$, and $\mathrm{TiO}_{2}$ were altered from those of SBW-2 to determine their effects on salt formation and crystallization of the glassresulting in SBW-3 through -10. Of the glasses formed from different ratios of SBW-2 through -10 and 2000 WM-180, it was found that SBW-9 could tolerate the highest SBW loading without the formation of a molten salt in ramp-heated crucible tests. These results are described in Peeler et al. (2001). SBW-9 was processed with between 30 and 35 mass\% of $2000 \mathrm{WM}-180$ simulant in the research-scale melter (RSM) at PNNL (Goles et al. 2001). Salt accumulation was seen for WLs greater than 32 mass\% (1.14 mass $\% \mathrm{SO}_{3}$ ). SBW-9-30 composition (SBW-9 additives, 30 mass\% of $2000 \mathrm{WM}-180$ simulant) was processed in the EV-16 at CETL (Perry et al. 2001). Salt was found to accumulate in the melter during this test. The cause of salt accumulation was determined to be a misbatch - the as-batched $\mathrm{SO}_{3}$ concentration was the equivalent of 1.35 mass $\%$, significantly higher than the target value of 1.07 mass $\%$. 


\subsection{Current Studies}

Using the constraints discussed in Section 3.0, the 2001 WM-180 waste-composition estimate in Table 2.1 and the property models listed in Section 4.0, additive and glass compositions were developed. Table 5.2 summarizes the additive compositions that were tested in this study.

SBW-11 was developed to be combined with 18.5 mass\% of $2001 \mathrm{WM}-180$ simulant. At that loading, the glass would contain 0.84 mass $\%$ of $\mathrm{SO}_{3}$ (assuming full retention). This WL was selected based on preliminary results ${ }^{(a)}$ from previous melter tests using SBW-9 (Goles et al. 2001; Perry et al. 2001). The preliminary analyses of the sulfur mass balance of these tests showed a minimum fraction of sulfur to the off-gas of $29 \%$ and a minimum $\mathrm{SO}_{3}$ loading in the glass of 0.59 mass $\%$, which, when combined, suggested that the minimum allowable $\mathrm{SO}_{3}$ loading would be 0.84 mass $\%$. At the time $\mathrm{SBW}$ 11 was being developed, the acceptable range of viscosity was given by $2 \leq \eta_{1150} \leq 10 \mathrm{~Pa} \cdot \mathrm{s}$, since CCIM processing was not yet being considered. The composition of SBW-11-18.5 ${ }^{\text {(b) }}$ is summarized in Table 5.3. The additives were selected to optimize for sulfur retention in the glass melt while maintaining WL, $\eta, \varepsilon, r_{B}, r_{N a}$, and $r_{L i}$ within acceptable ranges.

Previous studies suggested that high concentrations of alkali and alkali-earth elements would improve the solubility of $\mathrm{SO}_{3}$ in glass ( $\mathrm{Li}$ et al. 2001; Schreiber et al. 2000, for example). This is shown to increase sulfur retention as illustrated by the comparison of SBW-4 and -9 (Peeler et al. 2001). In the latter, higher concentrations of $\mathrm{CaO}$ and $\mathrm{Li}_{2} \mathrm{O}$ led to higher sulfur retention and higher sulfur loadings before salt was formed in crucible tests. It was speculated at the time of this formulation that combinations of alkali and alkali-earth would be more effective at raising sulfur retention and avoiding salt formation than would any single component. This theme is described in more detail in Vienna et al. (2002). This led to consideration of $\mathrm{CaO}, \mathrm{MgO}, \mathrm{Na}_{2} \mathrm{O}$, and $\mathrm{Li}_{2} \mathrm{O}$ as additive components. The addition of $\mathrm{V}_{2} \mathrm{O}_{5}$ in SBW-11 was to improve sulfur retention and help avoid salt accumulation, given that many researchers (Stefanovsky and Lifanov 1989, for example) have reported higher sulfur loadings in alkaliborosilicate glass melts by adding $\mathrm{V}_{2} \mathrm{O}_{5}$. Additions of between 10 and 20 mass $\% \mathrm{~V}_{2} \mathrm{O}_{5}$ were found to improve sulfur loading in glass to roughly $8 \%$ (as mass $\% \mathrm{SO}_{3}$ ). However, detailed analyses of the highsulfur, high-vanadium glasses showed phase separation, the scale of which increased with increasing $\mathrm{V}_{2} \mathrm{O}_{5}$ concentration (Stefanovsky and Lifanov 1989). A smaller concentration of $\mathrm{V}_{2} \mathrm{O}_{5}$ was added to the SBW-11-18.5 glass (4 mass\%) to avoid the immiscible phase separation while taking advantage of the capability of the melt to obtain higher $\mathrm{SO}_{3}$ loadings without salt accumulation. Sufficient $\mathrm{Fe}_{2} \mathrm{O}_{3}$ was added to the SBW-11-18.5 glass to assure that iron redox of the resulting glass could be precisely determined. This was necessary to allow for the tailoring of the reductant concentration in the feed. The amounts of $\mathrm{ZrO}_{2}, \mathrm{~B}_{2} \mathrm{O}_{3}$, and $\mathrm{SiO}_{2}$ were adjusted to obtain adequate $\eta_{1150}, \varepsilon_{1150}, r_{B}, r_{N a}$, and $r_{L i}$.

(a) The preliminary mass balances, reported by Darab et al. 2001, were used for the estimate. Final sulfur mass balances, reported by Perry et al. (2001) and Goles et al. (2001), were not available at the time of initial formulation work.

(b) Throughout the report, the nomenclature for glass compositions is as follows: frit composition, "-", loading of 2001 WM-180 simulant in mass\%. For example, SBW-11-30 refers to Frit SBW-11 at 30\% waste loading. 
Table 5.2. Additive Compositions Tested in This Study

\begin{tabular}{||l|c|c|c|c|c|c|c|c|c|c||}
\hline \hline Oxide & SBW-11 & SBW-12 & SBW-13 & SBW-14 & SBW-15 & SBW-16 & SBW-17 & SBW-18 & SBW-19 & SBW-20 \\
\hline $\mathrm{B}_{2} \mathrm{O}_{3}$ & 12.15 & 6.03 & 12.15 & 14.45 & 7.00 & 14.00 & 12.00 & 12.00 & 12.00 & 12.00 \\
\hline $\mathrm{CaO}$ & 5.02 & 5.02 & - & 5.02 & 8.00 & 7.00 & 2.00 & 2.00 & 2.00 & 4.00 \\
\hline $\mathrm{Fe}_{2} \mathrm{O}_{3}$ & 1.52 & 1.52 & 1.52 & 1.52 & 8.00 & --- & 12.00 & 12.00 & 12.00 & 12.00 \\
\hline $\mathrm{K}_{2} \mathrm{O}$ & --- & --- & 8.15 & --- & --- & --- & --- & --- & --- & --- \\
\hline $\mathrm{Li}_{2} \mathrm{O}$ & 6.11 & 6.11 & 6.11 & 6.11 & 6.00 & 6.00 & 4.00 & 3.00 & 3.00 & 3.00 \\
\hline $\mathrm{MgO}$ & 1.75 & 1.75 & --- & 1.75 & --- & --- & --- & --- & --- & --- \\
\hline $\mathrm{Na}_{2} \mathrm{O}$ & 1.90 & 6.98 & 1.90 & 1.90 & 7.00 & 2.00 & --- & 4.00 & 4.00 & 4.00 \\
\hline $\mathrm{SiO}_{2}$ & 64.23 & 65.27 & 62.85 & 66.81 & 64.00 & 71.00 & 70.00 & 64.00 & 62.00 & 60.00 \\
\hline $\mathrm{V}_{2} \mathrm{O}_{5}$ & 4.88 & 4.88 & 4.88 & --- & --- & --- & --- & 2.00 & 4.00 & 4.00 \\
\hline $\mathrm{ZrO}_{2}$ & 2.44 & 2.44 & 2.44 & 2.44 & --- & --- & --- & 1.00 & 1.00 & 1.00 \\
\hline $\mathrm{Sum} 100.00$ & 100.00 & 100.00 & 100.00 & 100.00 & 100.00 & 100.00 & 100.00 & 100.00 & 100.00 \\
\hline \hline
\end{tabular}

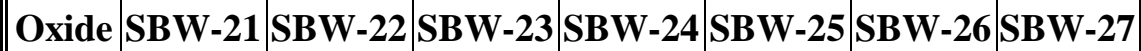

\begin{tabular}{|l|c|c|c|c|c|c|c|}
\hline $\mathrm{B}_{2} \mathrm{O}_{3}$ & 10.00 & 6.03 & 12.15 & 11.10 & 12.15 & 6.03 & 6.03 \\
\hline $\mathrm{CaO}$ & 4.00 & 5.02 & --- & 5.02 & 5.02 & 14.19 & 11.75 \\
\hline $\mathrm{Fe}_{2} \mathrm{O}_{3}$ & 12.00 & 1.52 & 1.52 & 1.52 & 12.00 & 1.52 & 1.52 \\
\hline $\mathrm{K}_{2} \mathrm{O}$ & --- & --- & 4.32 & --- & --- & --- & --- \\
\hline $\mathrm{Li} 2 \mathrm{O}$ & 3.00 & 6.11 & 6.11 & 6.11 & 3.44 & 3.52 & 4.08 \\
\hline $\mathrm{MgO}$ & --- & 1.75 & --- & 1.75 & 1.75 & 1.75 & 1.75 \\
\hline $\mathrm{Na}_{2} \mathrm{O}$ & 4.00 & 4.29 & 1.90 & 1.90 & --- & 1.90 & 1.90 \\
\hline $\mathrm{SiO}_{2}$ & 62.00 & 67.95 & 66.68 & 70.16 & 58.32 & 63.77 & 63.21 \\
\hline $\mathrm{V}_{2} \mathrm{O}_{5}$ & 4.00 & 4.88 & 4.88 & --- & 4.88 & 4.88 & 7.32 \\
\hline $\mathrm{ZrO}_{2}$ & 1.00 & 2.44 & 2.44 & 2.44 & 2.44 & 2.44 & 2.44 \\
\hline $\mathrm{Sum}^{2}$ & 100.00 & 100.00 & 100.00 & 100.00 & 100.00 & 100.00 & 100.00 \\
\hline \hline
\end{tabular}

Table 5.3. SBW-11-18.5 Glass Composition (mass\% oxides)

\begin{tabular}{|l|c||c|r||}
\hline \hline Oxide & Glass & Oxide & Glass \\
\hline $\mathrm{Al}_{2} \mathrm{O}_{3}$ & 5.09 & $\mathrm{Na}_{2} \mathrm{O}$ & 11.15 \\
\hline $\mathrm{B}_{2} \mathrm{O}_{3}$ & 9.97 & $\mathbf{S O}_{3}$ & $\mathbf{0 . 8 4}$ \\
\hline $\mathrm{CaO}$ & 4.49 & $\mathrm{SiO}_{2}$ & 52.35 \\
\hline $\mathrm{Fe}_{2} \mathrm{O}_{3}$ & 1.50 & $\mathrm{~V}_{2} \mathrm{O}_{5}$ & 3.99 \\
\hline $\mathrm{K}_{2} \mathrm{O}$ & 1.39 & $\mathrm{ZrO}_{2}$ & 1.99 \\
\hline $\mathrm{Li}_{2} \mathrm{O}$ & 4.98 & Others & 0.76 \\
\hline $\mathrm{MgO}$ & 1.50 & & \\
\hline
\end{tabular}

(a) Others composition can be obtained from the composition of $2001 \mathrm{WM}-180$ simulant in Table 2.1. 
SBW-12 to SBW-14 were formulated to investigate the effects of increasing the glass basicity number (Krämer 1991), removing $\mathrm{CaO}$ and $\mathrm{MgO}$, and removing $\mathrm{V}_{2} \mathrm{O}_{5}$ from SBW-11 on the sulfur retention in glass and salt formation. The calculated $1150^{\circ} \mathrm{C}$ viscosity of glasses with 18.5 mass $\% \mathrm{WL}$ was kept constant at the same value as in SBW-11-18.5 glass. In SBW-12, the $\mathrm{B}_{2} \mathrm{O}_{3}$ was decreased and the $\mathrm{Na}_{2} \mathrm{O}$ was increased from SBW-11, which is the general direction for the increase of basicity. The concentration of $\mathrm{B}_{2} \mathrm{O}_{3}$ in a glass with 18.5 mass\% SBW-12 was decreased to 5 mass\%, which is considered a lower boundary in typical "borosilicate" glasses (and the lower boundary of glass-propertymodel validity). Then, the concentration of $\mathrm{Na}_{2} \mathrm{O}$ was increased to have the calculated viscosity at the target value. In SBW-13, $\mathrm{CaO}$ and $\mathrm{MgO}$ were removed from $\mathrm{SBW}-11$, and $\mathrm{K}_{2} \mathrm{O}$ was increased until the predicted viscosity of a glass with 18.5 mass\% SBW-13 reached the target value. Among alkali components that can be used to adjust the viscosity, $\mathrm{Na}_{2} \mathrm{O}$ and $\mathrm{Li}_{2} \mathrm{O}$ were not used because of their tendency to increase PCT releases. In SBW-14, $\mathrm{V}_{2} \mathrm{O}_{5}$ was removed from SBW-11, and $\mathrm{B}_{2} \mathrm{O}_{3}$ was increased until the predicted viscosity of a glass with 18.5 mass\% SBW-14 reached the target value.

Regarding the basicity number used in formulating SBW-12, it is well known that the equilibrium solubility of sulfate increases as the glass basicity increases (Krämer 1991). The incorporation of sulfate in glass is not directly proportional to the equilibrium sulfate solubility because the kinetic factors are also involved in sulfate incorporation and may be more important than equilibrium. However, the effect of increasing basicity on sulfate incorporation was tested in this study to investigate the possible beneficial effect of increased sulfate solubility on sulfate incorporation.

As previously noted, SBW-12 to SBW-14 were formulated to evaluate the effect of basicity on sulfur retention while maintaining constant viscosity. Parallel with that effort was a series of scoping studies to evaluate the impacts of $\mathrm{CaO}, \mathrm{MgO}, \mathrm{Na}_{2} \mathrm{O}, \mathrm{Li}_{2} \mathrm{O}$, and $\mathrm{V}_{2} \mathrm{O}_{5}$ additions on sulfur solubility without constraining predicted properties to acceptable levels. The intent of this series of glasses was to vary the potential additive-composition region over a relatively broad range to gain some insight into the impacts of sulfur solubility as well as other glass properties of interest. SBW-15 to SBW-21 were also developed using an 18.5 mass\% WL basis.

Additives up to SBW-21 were formulated assuming that the resulting glasses will be processed in the JHCM. While this work was still in progress, the possibility of using the CCIM emerged, and thus the objectives of the development work shifted to the possible processing of a single glass using both CCIM and JHCM. Therefore, the calculated $\eta_{1150}$ was increased to the range appropriate for both melter technologies $\left(5 \leq \eta_{1150} \leq 10 \mathrm{~Pa} \cdot \mathrm{s}\right.$, with a target near $\left.7 \mathrm{~Pa} \cdot \mathrm{s}\right)$ in SBW-22 to SBW-27 based glasses.

SBW-22 to SBW-24 used the same guidelines as used in SBW-12 to SBW-14, respectively, except that the target viscosities changed to near $7 \mathrm{~Pa} \cdot \mathrm{s}$. SBW-25 was formulated with increased $\mathrm{Fe}_{2} \mathrm{O}_{3}$ from SBW-11 to explore the effect of $\mathrm{Fe}_{2} \mathrm{O}_{3}$ on the sulfur behavior. To compensate for the decrease of viscosity caused due to the increase of $\mathrm{Fe}_{2} \mathrm{O}_{3}$ concentration, $\mathrm{Na}_{2} \mathrm{O}$ was removed, and $\mathrm{Li}_{2} \mathrm{O}$ was decreased until the glass with 18.5 mass\% SBW-25 satisfied the viscosity target.

SBW-26 and SBW-27 were formulated to further investigate the effect of $\mathrm{CaO}$ and $\mathrm{V}_{2} \mathrm{O}_{5}$ on the sulfate incorporation. In SBW-26, $\mathrm{CaO}$ was increased from 4.5 to 12 mass $\% \mathrm{CaO}$ in a glass with 18.5 mass \% WL. The decrease in viscosity due to the increase of $\mathrm{CaO}$ was compensated by decreasing $\mathrm{B}_{2} \mathrm{O}_{3}$ and $\mathrm{Li}_{2} \mathrm{O}$ at a similar proportion. In SBW-27, both $\mathrm{CaO}$ and $\mathrm{V}_{2} \mathrm{O}_{5}$ were increased, and the viscosity was compensated by also decreasing $\mathrm{B}_{2} \mathrm{O}_{3}$ and $\mathrm{Li}_{2} \mathrm{O}$ at a similar proportion. 
Table 5.4 summarizes the predicted viscosity and PCT normalized releases for the glasses with 18.5 mass\% WL and SBW-11 to SBW-27 additive compositions. The effect of WL on sulfur behavior and glass properties was tested on glasses with selected additive compositions. These additive compositions were also used in glasses with varying WL (typically 15, 20, 25, and 30 mass\% 2001 WM180 simulant). Table 5.5 summarizes the calculated properties of these glasses. The testing results for all these glasses are given in Sections 6.0 and 7.0.

Table 5.4. Predicted Viscosity ( $\eta_{1150}$ in Pa $\left.\cdot \mathrm{s}\right)$ and $r_{i}$ Values $\left(\mathrm{in} \mathrm{g} / \mathrm{m}^{2}\right)$ for Glasses Formulated with 18.5 mass \% 2001 WM-180 Simulant Using $a_{i}$ Values from Table 4.1

\begin{tabular}{||c|c|c|c|c||}
\hline Glass & \multicolumn{4}{|c|}{ From Hrma et al. (2001) } \\
\hline SBW-xx-18.5 & $\boldsymbol{\eta}_{\mathbf{1 1 5 0}}$ & $\boldsymbol{r}_{\boldsymbol{B}}$ & $\boldsymbol{r}_{\boldsymbol{N} \boldsymbol{a}}$ & $\boldsymbol{r}_{\boldsymbol{L} \boldsymbol{i}}$ \\
\hline 11 & 4.6 & 0.8 & 1.0 & 0.9 \\
\hline 12 & 4.6 & 0.8 & 1.4 & 0.9 \\
\hline 13 & 4.6 & 1.0 & 1.2 & 1.1 \\
\hline 14 & 4.6 & 1.0 & 1.1 & 1.0 \\
\hline 15 & 2.9 & 0.7 & 1.3 & 0.7 \\
\hline 16 & 5.3 & 0.7 & 1.0 & 0.9 \\
\hline 17 & 14.6 & 0.5 & 0.4 & 0.5 \\
\hline 18 & 9.8 & 0.8 & 0.8 & 0.7 \\
\hline 19 & 8.7 & 0.9 & 0.9 & 0.7 \\
\hline 20 & 6.5 & 0.7 & 0.9 & 0.6 \\
\hline 21 & 8.6 & 0.5 & 0.7 & 0.5 \\
\hline 22 & 7.0 & 0.5 & 0.8 & 0.6 \\
\hline 23 & 6.9 & 1.1 & 1.0 & 1.1 \\
\hline 24 & 7.0 & 0.6 & 0.8 & 0.7 \\
\hline 25 & 6.9 & 0.4 & 0.5 & 0.4 \\
\hline 26 & 7.1 & 0.1 & 0.3 & 0.2 \\
\hline 27 & 7.1 & 0.1 & 0.4 & 0.2 \\
\hline \hline
\end{tabular}


Table 5.5. Predicted Viscosity ( $\boldsymbol{\eta}_{1150}$ in Pa $\left.\cdot \mathbf{s}\right)$ and $\boldsymbol{r}_{i}$ Values $\left(\mathrm{in} \mathrm{g} / \mathrm{m}^{2}\right.$ ) for Glasses Formulated with Various Loadings of 2001 WM-180 Simulant Using $a_{i}$ Values from Table 4.1 and for Comparison, the $a_{i}$ Values from Hrma et al. (1994)

\begin{tabular}{||l|c|c|c|c||}
\cline { 2 - 5 } \multicolumn{1}{c|}{} & \multicolumn{4}{c|}{ From Hrma et al. (2001) } \\
\hline Glass & $\boldsymbol{\eta}_{\mathbf{1 1 5 0}}$ & $\boldsymbol{r}_{\boldsymbol{B}}$ & $\boldsymbol{r}_{\boldsymbol{N} \boldsymbol{a}}$ & $\boldsymbol{r}_{\boldsymbol{L} \boldsymbol{i}}$ \\
\hline SBW-11-15 & 5.6 & 0.7 & 0.8 & 0.9 \\
\hline SBW-11-18.5 & 4.6 & 0.8 & 1.0 & 0.9 \\
\hline SBW-11-20 & 4.3 & 0.9 & 1.1 & 0.9 \\
\hline SBW-11-25 & 3.3 & 1.0 & 1.4 & 1.0 \\
\hline SBW-11-30 & 2.5 & 1.2 & 1.8 & 1.1 \\
\hline SBW-22-15 & 8.4 & 0.5 & 0.7 & 0.6 \\
\hline SBW-22-18.5 & 7.0 & 0.5 & 0.8 & 0.6 \\
\hline SBW-22-20 & 6.4 & 0.5 & 0.9 & 0.6 \\
\hline SBW-22-25 & 4.8 & 0.7 & 1.1 & 0.7 \\
\hline SBW-22-30 & 3.6 & 0.8 & 1.5 & 0.8 \\
\hline SBW-23-15 & 8.5 & 1.0 & 0.9 & 1.1 \\
\hline SBW-23-18.5 & 6.9 & 1.1 & 1.0 & 1.1 \\
\hline SBW-23-20 & 6.4 & 1.1 & 1.1 & 1.1 \\
\hline SBW-23-25 & 4.8 & 1.3 & 1.5 & 1.2 \\
\hline SBW-23-30 & 3.6 & 1.5 & 1.9 & 1.3 \\
\hline SBW-24-15 & 8.4 & 0.5 & 0.6 & 0.7 \\
\hline SBW-24-18.5 & 7.0 & 0.6 & 0.8 & 0.7 \\
\hline SBW-24-20 & 6.4 & 0.6 & 0.8 & 0.7 \\
\hline SBW-24-25 & 4.9 & 0.7 & 1.1 & 0.8 \\
\hline SBW-24-30 & 3.7 & 0.9 & 1.4 & 0.9 \\
\hline SBW-25-15 & 8.6 & 0.3 & 0.4 & 0.4 \\
\hline SBW-25-18.5 & 6.9 & 0.4 & 0.5 & 0.4 \\
\hline SBW-25-20 & 6.3 & 0.4 & 0.5 & 0.4 \\
\hline SBW-25-25 & 4.7 & 0.5 & 0.7 & 0.5 \\
\hline SBW-25-30 & 3.4 & 0.6 & 0.9 & 0.5 \\
\hline \hline
\end{tabular}




\subsection{Batch-Chemical Testing}

A series of crucible tests was performed using reagent-grade oxides, carbonates, and boric acid before the WM-180 liquid simulant was prepared. Glasses produced in this series were coupled with the 2001 SBW simulant composition (see Table 2.1) with the candidate additive compositions (see Table 5.2). This section discusses the experimental procedures and results of these preliminary or scoping tests using batch chemicals as the SBW simulant. The objective of these tests was to assess various additives components and their effects on sulfate solubility and glass properties of interest.

Based on results of previous studies with SBW, using only laboratory-scale tests to predict the accumulation of a salt layer during actual melter processing adds risk. More specifically, differences in sulfur partitioning have been observed between laboratory-scale testing and melter demonstrations. Not only can there be an effect of testing scale on sulfur partitioning, but the use of reagent-grade chemicals and the liquid-feed tests can also produce differences as well. Although differences can exist, the use of laboratory-scale tests has been effective in the past to down-select potential additive composition candidates that will be carried forward in the testing methodology established as one transitions from the dry-fed, small-scale laboratory tests to slurry-fed melter demonstrations. The crucible-scale tests only lower the risk of salt formation and/or accumulation in the melter; they do not eliminate it.

\subsection{Experimental}

Each batch was prepared from the proper proportions of reagent-grade metal oxides, carbonates, $\mathrm{H}_{3} \mathrm{BO}_{3}$, and salts in 150-g batches using standard batching and melting procedures. Batch sheets were filled out as the materials were weighed. Once batched, the glasses were melted using a standard thermal heat treatment. In general, the raw materials were thoroughly mixed and placed into a $95 \% \mathrm{Pt} / 5 \% \mathrm{Au}$ $250-\mathrm{mL}$ crucible. The batch was subsequently placed into a high-temperature furnace, and the temperature was increased at $\sim 8^{\circ} \mathrm{C} / \mathrm{min}$ until the target melt temperature $\left(1150^{\circ} \mathrm{C}\right)$ was reached. After an isothermal hold at $1150^{\circ} \mathrm{C}$ for $1.0 \mathrm{~h}$, the crucible was removed, and the glass was poured onto a clean stainless steel plate and allowed to air cool. Visual observations on the resulting pour patty and residual crucible glass were documented.

The pour patty and residual crucible glass were ground, and the crushed glass was subsequently transferred to its original $95 \% \mathrm{Pt} / 5 \% \mathrm{Au} 250-\mathrm{mL}$ crucible for a second melt at $1150^{\circ} \mathrm{C}$. After an isothermal hold at $1150^{\circ} \mathrm{C}$ for $1.0 \mathrm{~h}$, the crucible was removed, and the glass was poured onto a clean stainless steel plate and allowed to air cool. Visual observations on the resulting pour patty and residual crucible glass were documented. Approximately $140 \mathrm{~g}$ of glass were removed (poured) from the crucible while $\sim 10 \mathrm{~g}$ remained in the crucible along the walls. The pour patty was used as a sampling stock for the various heat treatments and property measurements (i.e., chemical composition, crystallinity, viscosity, and/or durability).

To bound the effects of thermal history on the product performance, approximately $25 \mathrm{~g}$ of each glass was heat treated to simulate cooling along the centerline of a DWPF-type canister (Marra and Jantzen 1993). The temperature schedule used to simulate canister centerline cooling (CCC) is listed in Table 6.1. This terminology will be used in this report to differentiate samples from different cooling schedules (quenched versus CCC). 
Table 6.1. Centerline Canister Cooling Schedule Utilized

\begin{tabular}{||c|c|c|c||}
\hline \hline Step & Ramp $\left({ }^{\circ} \mathbf{C} / \mathbf{m i n}\right)$ & Target Temperature $\left({ }^{\circ} \mathbf{C}\right)$ & Dwell (h) \\
\hline 1 & 10 & 1150 & 4 \\
\hline 2 & 8 & 926 & 0.1 \\
\hline 3 & 1 & 779 & 2.8 \\
\hline 4 & 1 & 715 & 3.4 \\
\hline 5 & 1 & 598 & 4.2 \\
\hline 6 & 1 & 490 & 4.3 \\
\hline 7 & 1 & 382 & 7.4 \\
\hline 8 & 1 & 70 & End \\
\hline
\end{tabular}

To confirm that the "as-fabricated" (or quenched) glasses corresponded to the defined target compositions, a representative sample from each glass pour patty was analyzed. Concentrations (as mass \%) for the cations of interest were measured by inductively coupled plasma-atomic emission spectroscopy (ICP-AES). To assess the performance of the ICP over the course of these analyses, glass standards were intermittently analyzed.

Homogeneity was evaluated (visual and optical microscopy [minimum of $100 \times$ magnification]) and documented for each SBW glass (both quenched and CCC samples). Homogeneity in this context refers to the presence of crystallization and/or a salt layer, not the presence of glass-in-glass phase separation (amorphous phase separation).

Roughly 5-g samples of select as-fabricated (quenched) SBW glasses were heat treated at $1050^{\circ} \mathrm{C}$ for $24 \mathrm{~h}$ in a Pt/Rh crucible with a tight-fitting lid. Visual observations and optical microscopy analyses were made to assess the presence of crystallization or droplets of $\mathrm{Na}_{2} \mathrm{SO}_{4}$ (as observed by Vienna et al. 1999). Note that only a single isothermal heat treatment was performed to assess the $1050^{\circ} \mathrm{C}$ acceptance criterion. The $T_{L}$ was not formally determined—only an assessment of $T_{L}$ with respect to the acceptance criterion.

High-temperature $\eta$ was measured as a function of temperature (T) using a spindle viscometer for selected SBW glasses. The measurements were obtained using standard procedures (SRTC 1999; Schumacher and Peeler 1998), which are compliant with ASTM C 965-81 (ASTM 1990). Hightemperature $\eta$ data were measured over the maximum temperature range allowable for each glass. The low-temperature limit was based on the effects of crystallization on the melt pool. The high-temperature limit was based on reducing the effects of volatilization. To validate the glass- $\eta$ data, the $\eta$ of the Batch 1 standard glass (Schumacher and Peeler 1998) was measured intermittently during the viscosity determinations. Viscosity at $1150^{\circ} \mathrm{C}\left(\eta 1150^{\circ} \mathrm{C}\right)$ for each glass was calculated from a Vogel-TammanFulcher fit of the measured data.

Electrical conductivity $(\varepsilon)$ was measured as a function of both temperature and frequency using an apposing plate probe as described previously (Hrma et al. 1994).

The PCT was performed on each glass to assess chemical durability (ASTM 1998). The PCT was conducted in triplicate for each SBW glass (both quenched and CCC samples). Also included in this experimental test matrix were the EA glass (Jantzen et al. 1993), the Approved Reference Material 
(ARM-1) glass, and blanks. Samples were ground, washed, and prepared according to procedure. Fifteen $\mathrm{mL}$ of Type I ASTM water was added to $1.5 \mathrm{~g}$ of glass in stainless steel vessels. The vessels were closed, sealed, and placed in an oven at $90 \pm 2{ }^{\circ} \mathrm{C}$. Samples were left at $90^{\circ} \mathrm{C} \pm 2{ }^{\circ} \mathrm{C}$ for 7 days. The resulting solutions (once cooled) were sampled (filtered and acidified), labeled, and analyzed.

Normalized release rates were calculated based on targeted compositions using the average of the logs of the leachate concentrations.

\subsection{Results}

\subsubsection{Chemical Composition}

Appendix A summarizes the target and measured compositions for all the SBW glasses. Overall, comparisons between the measured and targeted compositions suggest that there were no significant problems in the batching or fabrication of the study glasses.

\subsubsection{Homogeneity}

Table 6.2 summarizes the visual observations of homogeneity for each SBW glass as a function of WL. Observations after the initial and second melts at $1150^{\circ} \mathrm{C}$ and following the $\mathrm{CCC}$ heat treatment are shown. Appendix B provides a more detailed description of each glass. Again, it should be noted that these glasses were produced using reagent-grade oxides, carbonates, and boric acid (not using the liquid simulant). This evaluation provides an indication of the potential advantages of the additive-composition changes in terms of $\mathrm{SO}_{3}$ retention in glass.

It is interesting to note that no sign of salt was observed after the second melt for those glasses in which a salt layer was observed on the surface of the melt (or above the melt line) after the initial melt at $1150^{\circ} \mathrm{C}$. No effort was made to remove the salt after the initial melt. In fact, a special effort was made to transfer as much of the salt layer as possible to the second melt — where this became a real problem was the observation of the yellow salt plated on the crucible wall above the melt line. Before the second melt, the glasses with $\mathrm{SO}_{3}$ layers (where applicable) were ground to a fine powder. The lack of salt layers in the second melts may be a function of the melting procedure, which may suggest that the $\mathrm{SO}_{3}$ solubility limit had not been exceeded. To confirm this, a comparison of the target and measured $\mathrm{SO}_{3}$ concentrations in glass should be reviewed (see Table 6.3).

As previously mentioned, the results of earlier studies with SBW indicate that the sole use of crucible tests to predict the accumulation of a salt layer during actual melter processing adds risk. More specifically, differences in sulfur behavior have been observed between crucible testing and melter demonstrations. ${ }^{a}$ The crucible tests only lower the risk of salt formation and/or accumulation in the melter; they do not eliminate it.

Typically, salt formation occurs in crucible melts made from oxide and carbonate raw materials at lower sulfur concentrations than larger scale tests using simulants. 
Table 6.2. Visual Observations of Homogeneity for Quenched and CCC SBW Glasses

\begin{tabular}{|c|c|c|c|c|}
\hline Glass & $\overline{\mathbf{W L}}$ & Initial Melt & Second Melt & $\overline{\mathrm{CCC}}$ \\
\hline \multirow[t]{2}{*}{ SBW-11 } & 18.5 & Homogeneous & Homogeneous & Homogeneous \\
\hline & 30 & Homogeneous & Homogeneous & Homogeneous \\
\hline SBW-12 & 18.5 & Homogeneous & Homogeneous & Homogeneous \\
\hline SBW-13 & 18.5 & Homogeneous & Homogeneous & Homogeneous \\
\hline SBW-14 & 18.5 & Homogeneous & Homogeneous & Homogeneous \\
\hline SBW-15 & 18.5 & Homogeneous & Homogeneous & Homogeneous \\
\hline SBW-16 & 18.5 & Homogeneous & Homogeneous & Homogeneous \\
\hline SBW-17 & 18.5 & Salt & Homogeneous & Homogeneous \\
\hline SBW-18 & 18.5 & Salt & Homogeneous & Homogeneous \\
\hline SBW-19 & 18.5 & Salt & Homogeneous & Homogeneous \\
\hline SBW-20 & 18.5 & Salt & Homogeneous & Homogeneous \\
\hline SBW-21 & 18.5 & Salt & Homogeneous & Homogeneous \\
\hline \multirow[t]{4}{*}{ SBW-22 } & 15 & Homogeneous & Homogeneous & Homogeneous \\
\hline & 18.5 & Homogeneous & Homogeneous & Homogeneous \\
\hline & 20 & Homogeneous & Homogeneous & Homogeneous \\
\hline & 25 & Salt & Homogeneous & Homogeneous \\
\hline \multirow[t]{4}{*}{ SBW-23 } & 15 & Homogeneous & Homogeneous & Homogeneous \\
\hline & 18.5 & Homogeneous & Homogeneous & Homogeneous \\
\hline & 20 & Homogeneous & Homogeneous & Homogeneous \\
\hline & 25 & Homogeneous & Homogeneous & Homogeneous \\
\hline SBW-24 & 18.5 & Salt & Homogeneous & Homogeneous \\
\hline \multirow[t]{4}{*}{ SBW-25 } & 15 & Homogeneous & Homogeneous & Homogeneous \\
\hline & 18.5 & Homogeneous & Homogeneous & Homogeneous \\
\hline & 20 & Homogeneous & Homogeneous & Homogeneous \\
\hline & 25 & Homogeneous & Homogeneous & Homogeneous \\
\hline \multirow[t]{2}{*}{ SBW-26 } & 18.5 & Homogeneous & Homogeneous & Homogeneous \\
\hline & 25 & Salt & Homogeneous & Homogeneous \\
\hline \multirow[t]{2}{*}{ SBW-27 } & 18.5 & Homogeneous & Homogeneous & Homogeneous \\
\hline & 25 & Salt & Homogeneous & Homogeneous \\
\hline
\end{tabular}


Table 6.3. Comparison of Target and Measured $\mathrm{SO}_{3}$ Concentrations

\begin{tabular}{|c|c|c|c|c|c|}
\hline Glass & WL & $\mathrm{SO}_{3}$ Target $^{(\mathbf{a})}$ & $\mathrm{SO}_{3}$ Measured $^{(\mathbf{b})}$ & Retention \% Relative & Salt Layer Observed $^{(\mathrm{c})}$ \\
\hline \multirow[t]{2}{*}{ SBW-11 } & 18.5 & 0.83 & 0.749 & 90 & No \\
\hline & 30 & NM & NM & --- & No \\
\hline SBW-12 & 18.5 & 0.83 & 0.824 & 99 & No \\
\hline SBW-13 & 18.5 & 0.83 & 0.819 & 99 & No \\
\hline SBW-14 & 18.5 & 0.83 & 0.722 & 87 & No \\
\hline SBW-15 & 18.5 & 0.83 & 0.844 & 102 & No \\
\hline SBW-16 & 18.5 & 0.83 & 0.737 & 89 & No \\
\hline SBW-17 & 18.5 & 0.83 & 0.477 & 57 & Yes \\
\hline SBW-18 & 18.5 & 0.83 & 0.602 & 73 & Yes \\
\hline SBW-19 & 18.5 & 0.83 & 0.572 & 69 & Yes \\
\hline SBW-20 & 18.5 & 0.83 & 0.589 & 71 & Yes \\
\hline SBW-21 & 18.5 & 0.83 & 0.582 & 70 & Yes \\
\hline \multirow[t]{4}{*}{ SBW-22 } & 15 & 0.68 & 0.599 & 88 & No \\
\hline & 18.5 & 0.83 & 0.737 & 89 & No \\
\hline & 20 & 0.91 & 0.806 & 89 & No \\
\hline & 25 & 1.14 & 1.074 & 94 & Yes \\
\hline \multirow[t]{4}{*}{ SBW-23 } & 15 & 0.68 & 0.694 & 102 & No \\
\hline & 18.5 & 0.83 & 0.914 & 110 & No \\
\hline & 20 & 0.91 & 1.01 & 111 & No \\
\hline & 25 & 1.14 & 1.35 & 118 & No \\
\hline SBW-24 & 18.5 & 0.83 & NM & --- & No \\
\hline \multirow[t]{4}{*}{ SBW-25 } & 15 & 0.68 & 0.654 & 96 & No \\
\hline & 18.5 & 0.83 & 0.734 & 88 & No \\
\hline & 20 & 0.91 & 0.734 & 81 & No \\
\hline & 25 & 1.14 & 1.084 & 95 & Yes \\
\hline \multirow[t]{2}{*}{ SBW-26 } & 18.5 & 0.83 & 0.754 & 91 & No \\
\hline & 25 & 1.14 & 1.08 & 95 & Yes \\
\hline \multirow[t]{2}{*}{ SBW-27 } & 18.5 & 0.83 & 0.782 & 94 & No \\
\hline & 25 & 1.14 & 1.05 & 92 & Yes \\
\hline \multicolumn{6}{|c|}{$\begin{array}{l}\text { (a) Target } \mathrm{SO}_{3} \text { concentrations are precise to withing } \pm 1 \% \text { (relative). } \\
\text { (b) Measured } \mathrm{SO}_{3} \text { concentrations are precise to within } \pm 10 \% \text { (relative) }\end{array}$} \\
\hline
\end{tabular}

\subsection{3 $1050{ }^{\circ} \mathrm{C}$ Isothermal Heat Treatment}

Table 6.4 summarizes the visual and optical microscopy results of select glasses. All samples tested were homogeneous, indicating that the $T_{L}$ is less than $1050^{\circ} \mathrm{C}$ (meeting one of the processing constraints as listed in Table 3.1). It should be noted that for those glasses in which a salt layer was observed after initial fabrication, the salt layer may not have been observed after the second melt (refer to Appendix B). Therefore, the $T_{L}$ results of these glasses should be viewed and used accordingly. 
Table 6.4. Visual Observations of Homogeneity for Quenched and CCC SBW Glasses

\begin{tabular}{|c|c|c|c|c|c|}
\hline Glass & WL & $\begin{array}{c}1^{1050}{ }^{\circ} \mathrm{C} \text { Heat } \\
\text { Treatment }\end{array}$ & Glass & WL & $\begin{array}{c}1050^{\circ} \mathrm{C} \text { Heat } \\
\text { Treatment }\end{array}$ \\
\hline \multirow[t]{2}{*}{ SBW-11 } & 18.5 & Homogeneous & \multirow[t]{4}{*}{ SBW-23 } & 15 & Homogeneous \\
\hline & 30 & Homogeneous & & 18.5 & Homogeneous \\
\hline SBW-12 & 18.5 & Homogeneous & & 20 & Homogeneous \\
\hline SBW-13 & 18.5 & Homogeneous & & 25 & Homogeneous \\
\hline SBW-14 & 18.5 & Homogeneous & SBW-24 & 18.5 & Homogeneous \\
\hline SBW-15 & 18.5 & Homogeneous & \multirow[t]{4}{*}{ SBW-25 } & 15 & Homogeneous \\
\hline SBW-16 & 18.5 & Homogeneous & & 18.5 & Homogeneous \\
\hline SBW-17 & 18.5 & Homogeneous & & 20 & Homogeneous \\
\hline SBW-18 & 18.5 & Homogeneous & & 25 & Homogeneous \\
\hline SBW-19 & 18.5 & Homogeneous & \multirow[t]{2}{*}{ SBW-26 } & 18.5 & Homogeneous \\
\hline SBW-20 & 18.5 & Homogeneous & & 25 & Homogeneous \\
\hline SBW-21 & 18.5 & Homogeneous & \multirow[t]{2}{*}{ SBW-27 } & 18.5 & Homogeneous \\
\hline \multirow[t]{4}{*}{ SBW-22 } & 15 & Homogeneous & & 25 & Homogeneous \\
\hline & 18.5 & Homogeneous & & & \\
\hline & 20 & Homogeneous & & & \\
\hline & 25 & Homogeneous & & & \\
\hline
\end{tabular}

\subsubsection{Viscosity}

High-temperature $\eta$ was measured as a function of temperature (T) using a spindle viscometer for selected SBW glasses. Appendix C summarizes the measured viscosity data for each SBW glass. Table 6.5 summarizes the $\eta_{1150^{\circ} \mathrm{C}}$ for each glass as calculated from a Vogel-Tamman-Fulcher fit of the measured data.

Table 6.5. Calculated Viscosity at $1150^{\circ} \mathrm{C}\left(\eta 1150^{\circ} \mathrm{C}\right)$ for Select Glasses Based on the Vogel-Tamman-Fulcher Fit of the Measured Data

\begin{tabular}{|l|c||l|c||}
\hline \hline Glass ID & Estimated $\eta_{\mathbf{1 1 5 0}}{ }^{\circ} \mathbf{C}($ Pa-s $)$ & Glass ID & Estimated $\boldsymbol{\eta}_{\mathbf{1 1 5 0}}{ }^{\circ} \mathbf{C}(\mathbf{P a}-\mathbf{s})$ \\
\hline SBW-11-18.5 & 3.90 & SBW-22-25 & 5.14 \\
\hline SBW-15-18.5 & 3.07 & SBW-23-18.5 & 5.66 \\
\hline SBW-17-18.5 & 15.76 & SBW-25-15 & 7.94 \\
\hline SBW-20-18.5 & 5.56 & SBW-25-18.5 & 6.28 \\
\hline SBW-21-18.5 & 6.86 & SBW-25-20 & 5.67 \\
\hline SBW-22-15 & 8.18 & SBW-25-25 & 4.28 \\
\hline SBW-22-18.5 & 6.81 & SBW-26-18.5 & 6.55 \\
\hline SBW-22-20 & 6.47 & SBW-27-18.5 & 6.32 \\
\hline
\end{tabular}

\subsubsection{Electrical Conductivity}

The electrical conductivity $(\varepsilon)$ of molten SBW-22-20 glass was measured. The $\varepsilon-\mathrm{T}-$ frequency data are listed in Table 6.6 and plotted in Figure 6.1. At 1-kHz frequency and above, the $\varepsilon$ is relatively 
independent of frequency. At this frequency, the temperature effect on $\varepsilon$ can be described by an Arrhenius function:

$$
\ln [\varepsilon]=8.696-7028.6 / \mathrm{T}
$$

where $\mathrm{T}$ is in Kelvin and $\varepsilon$ is in $\mathrm{S} / \mathrm{m}$. This would yield an $\varepsilon$ of $38 \mathrm{~S} / \mathrm{m}$ at the nominal melter operating temperature of $1150^{\circ} \mathrm{C}$.

Table 6.6. Electrical Conductivity Data for SBW-22-20 Glass Melt

\begin{tabular}{||r|c|c||}
\hline \hline $\mathbf{T}\left({ }^{\circ} \mathbf{C}\right)$ & $\boldsymbol{\varepsilon}(\mathbf{S} / \mathbf{m})$ & Freq $(\mathbf{H z})$ \\
\hline 1243 & 43.0 & 100 \\
\hline 1144 & 31.8 & 100 \\
\hline 1044 & 22.9 & 100 \\
\hline 945 & 15.3 & 100 \\
\hline 1243 & 56.9 & 1000 \\
\hline 1144 & 42.4 & 1000 \\
\hline 1044 & 29.4 & 1000 \\
\hline 945 & 18.3 & 1000 \\
\hline 1243 & 62.0 & 10000 \\
\hline 1144 & 45.5 & 10000 \\
\hline 1044 & 30.9 & 10000 \\
\hline 945 & 18.9 & 10000 \\
\hline
\end{tabular}

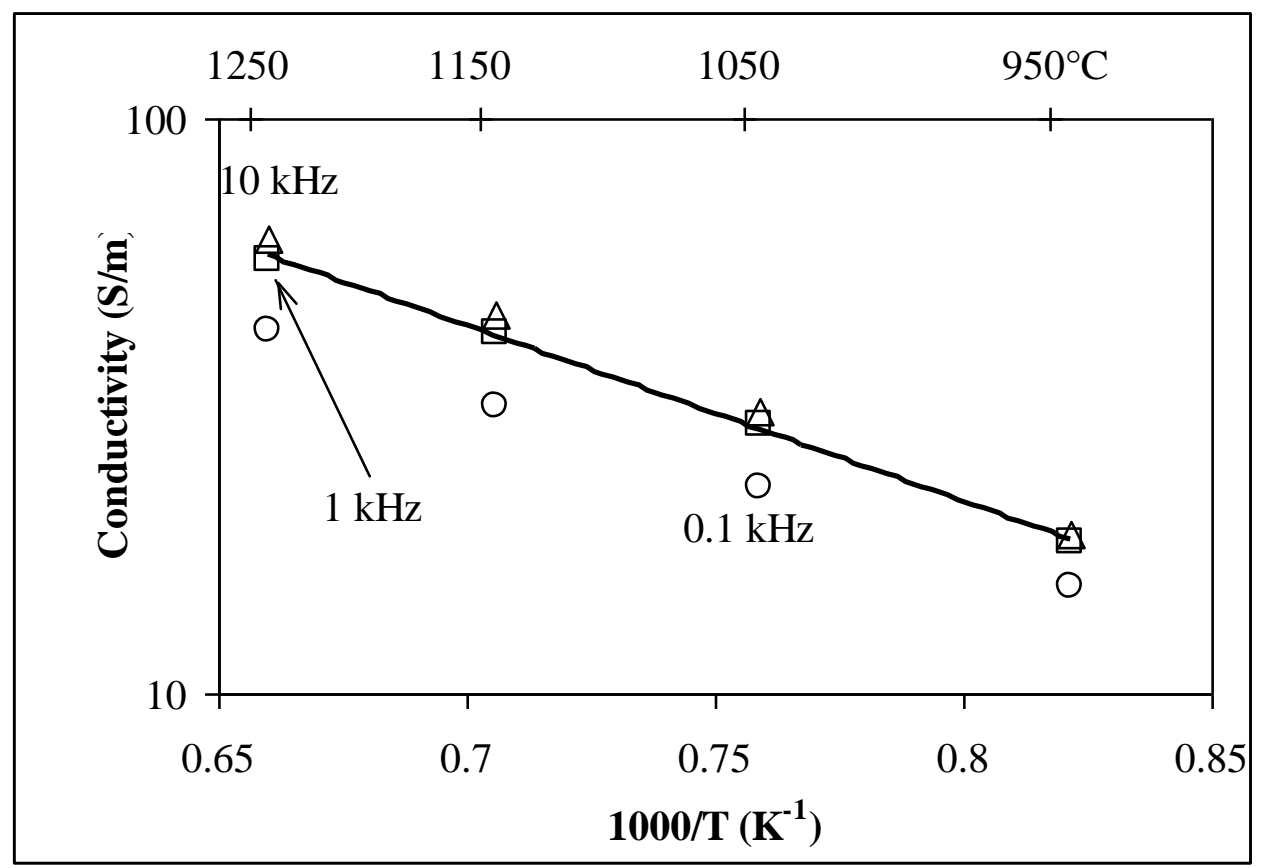

Figure 6.1. Electrical Conductivity of SBW-22-20 Melt as a Function of Inverse Temperature 


\subsubsection{PCT}

Table 6.7 summarizes the PCT results for both quenched and CCC SBW glasses as a function of WL. Note that the PCT was not performed on the SBW-26 and SBW-27 glasses. With respect to the conservative acceptance criteria being used in this study $\left(<1 \mathrm{~g} / \mathrm{m}^{2}\right.$ for each element of interest), the only glasses (based on measurements) that are not acceptable are SBW-11 (18.5\% WL), SBW-13 (18.5\% WL), SBW-14 (18.5\% WL), and SBW-23 (all WLs) glasses. If one were to move this conservative constraint to $1.5 \mathrm{~g} / \mathrm{m}^{2}$, only the SBW-13 and SBW-23 glasses would fail. Based on PCT releases, SBW-13 and SBW-23 are not considered potential candidates, given that they yield unacceptable PCT responses, even though the solubility of $\mathrm{SO}_{3}$ appears to promising.

Table 6.7. Normalized B, Li, Na, and Si Releases $\left(\mathrm{g} / \mathrm{m}^{2}\right)$ from PCT of Quenched and CCC SBW Glasses Samples

\begin{tabular}{|c|c|c|c|c|c|c|c|c|c|}
\hline & & & $\overline{\mathbf{Q u}}$ & ched & & & $\mathrm{CC}$ & & \\
\hline Glass & WL & $r_{B}$ & $r_{L i}$ & $r_{N a}$ & $r_{S i}$ & $r_{B}$ & $r_{L i}$ & $r_{N a}$ & $r_{S i}$ \\
\hline SBW-11 & 18.5 & 1.48 & 1.53 & 1.33 & 0.51 & 1.31 & 1.37 & 1.21 & 0.48 \\
\hline SBW-11 & 30 & & & 0.72 & & 0.49 & 0.51 & 0.60 & 0.25 \\
\hline SBW-12 & & 0.5 & & & & 0.5 & 0.80 & 0.83 & 0.34 \\
\hline SBW-13 & 18.5 & 14.88 & 13.48 & 13.34 & & 14.93 & 13.47 & 13.33 & 4.18 \\
\hline SBW-14 & 18.5 & 1.05 & & 0.95 & & 0.91 & 0.90 & 0.84 & 0.37 \\
\hline SBW-15 & 18.5 & & & 69 & & 0.2 & & 0.56 & 0.14 \\
\hline SBW-16 & 185 & & & 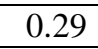 & & & & 0. & 0.10 \\
\hline SBW-17 & 18.5 & & & & & 0 . & 0.21 & 0 . & 0.11 \\
\hline SBW-1 & 18.5 & & & 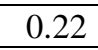 & & 0 . & 0.36 & 0 . & 0.16 \\
\hline SBW-1 & 18.5 & & & & & 0 . & 0.50 & 0 . & 0.19 \\
\hline SBW-20 & 18.5 & & & $0=$ & & 0 . & 0.38 & 0 . & 0.15 \\
\hline SBW-2 & 18.5 & & & 03 & & 0 . & 0.35 & 0 . & 0.15 \\
\hline SBW-22 & 15 & & & 0.8 & & 0 . & 0.72 & 0 . & 0.34 \\
\hline SBW-22 & 18.5 & & & 0.56 & & 0 . & 0.60 & 0.55 & 0.27 \\
\hline SBW-22 & 20 & & & & & 0 . & 0.55 & 0.52 & 0.24 \\
\hline SBW-22 & 25 & & & 0.80 & & 0 . & 0.69 & 0.71 & 0.28 \\
\hline SBW-23 & 15 & & & 4.34 & & 6. & 6.65 & 4.16 & 1.63 \\
\hline SBW-23 & 18.5 & & & & & & 7.08 & 5.23 & 1.89 \\
\hline SBW-23 & 20 & & & & & 7.6 & 6.67 & 6.44 & 1.98 \\
\hline SBW-23 & 25 & & & 9.44 & & 7.73 & 6.50 & 8.16 & 2.07 \\
\hline SBW-2 & 18.5 & & & & & & 0.67 & 0.63 & 0.31 \\
\hline SBW-25 & 15 & & & & & & 0.47 & 0.30 & 0.17 \\
\hline SBW-25 & 18.5 & 0. & & 0.37 & & 0.32 & $\mathrm{NR}^{\mathrm{a}}$ & 0.31 & 0.14 \\
\hline & 20 & & & 0.35 & & 0.3 & 0.36 & 0.35 & 0.14 \\
\hline SBW-25 & 25 & 0.36 & 0.34 & 0.49 & 0.14 & 0.34 & 0.33 & 0.47 & 0.14 \\
\hline
\end{tabular}

Figure 6.2 provides a visual comparison of $r_{i}\left(\mathrm{~g} / \mathrm{m}^{2}\right)$ values for quenched and CCC samples of the SBW glasses. These results were derived using the targeted compositions. For those glasses shown below the 1:1 correlation line in Figure 6.2, the CCC sample is more durable (lower $r_{i}$ ) than its quenched counterpart, for example, the SBW-23 based glasses. The durability criteria are not met for SBW-23 and the SBW-13 based glasses (the latter being the 18.5 mass\% WL glass, which yielded an $r_{B}$ of

\footnotetext{
${ }^{\mathrm{a}} \mathrm{Li}$ value not reported (NR) for SBW-25-18.5ccc.
} 
approximately $15 \mathrm{~g} / \mathrm{m}^{2}$ ). The low durabilities of these two groups of glasses are primarily a result of the high-alkali content of the glasses with SBW-13 and SBW-23 having 16.16 and 12.33 mass\% sum of alkali, respectively.

The normalized releases from SBW-11 and SBW-14 at 18.5\% WL also do not meet the conservative $<1 \mathrm{~g} / \mathrm{m}^{2}$ acceptance criterion (although their releases are well below those of the EA glass).

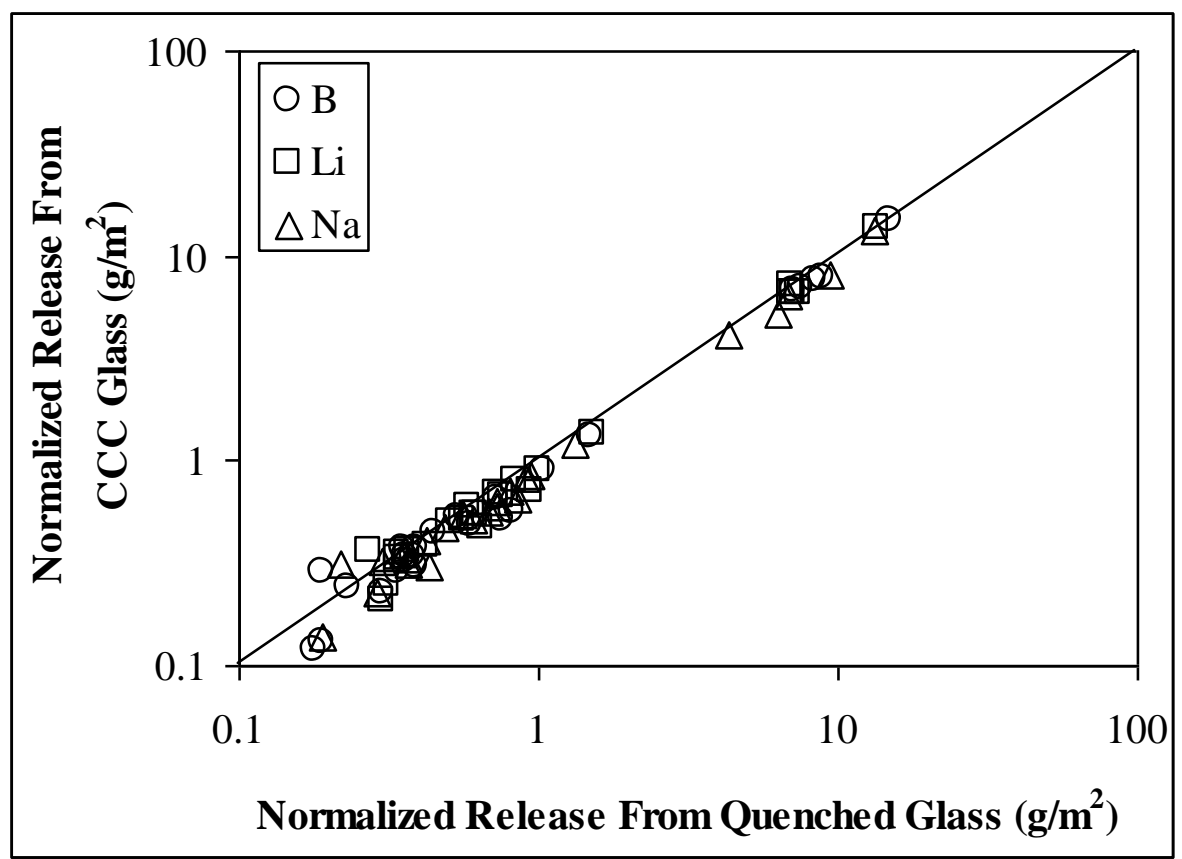

Figure 6.2. Comparison of $\boldsymbol{r}_{i}$ for Quenched and CCC Glasses

\subsection{Summary of Batch-Chemical Testing}

Based on the initial scoping tests using batch chemicals, various candidate additive compositions could be eliminated from further consideration based on the acceptance criteria. In terms of solubility, those glasses in which salt was observed provide an indication that the compositional changes were not conducive to maximizing $\mathrm{SO}_{3}$ solubility. As with previous studies, these results suggested that high concentrations of alkali and alkali-earth elements would improve the incorporation of $\mathrm{SO}_{3}$ in glass. In fact, it appears that combinations of alkali and alkali-earth are more effective at raising sulfur retention and avoiding salt formation than any single component. However, a quantitative relationship has not yet been developed. Based on this criterion, SBW-17, $-18,-19,-20,-21$, and -24 were excluded from further study.

With respect to the PCT response, SBW-13 and SBW-23 were not considered as potential candidates, given their high $r_{i}$ values, even though both retained targeted $\mathrm{SO}_{3}$ concentrations over the WL range evaluated. Again, the presence of high concentrations of alkali and/or alkali-earth enhances sulfur incorporation, but also increases $r_{i}$. 
Viscosity measurements relative to acceptance criteria also aided in the down-selection process of potential candidates for recommendation. Given that the acceptance range for viscosity was 2 to $10 \mathrm{~Pa}-\mathrm{s}$ (for JHCM) and 5 to $10 \mathrm{~Pa}-\mathrm{s}$ (for CCIM), SBW-17 failed both criteria with SBW-11 (18.5\% WL), -15 $(18.5 \% \mathrm{WL})$, and -25 (25\% WL), failing the CCIM criterion on the low side (i.e., < the 5 Pa-s lower limit).

None of the heat treatments at $1050^{\circ} \mathrm{C}$ indicated devitrification. Thus, this property did not eliminate any of the candidates from further consideration.

Based on the batch chemical testing results, only the following 6 of the 17 candidates produced glasses that met all of the constraints: SBW-12, -14, -16, -22, -26, and -27 (although it should be noted that the PCT was not performed on -26 and -27 based glasses). 


\subsection{Slurry Simulant Testing}

To gain a better understanding of the effects of glass composition on sulfur partitioning from a slurryfed melter operation, tests were performed to better simulate that process than was allowed by the crucible melts discussed in Section 6.0. This section discusses the fabrication of WM-180 simulant, the test experiments, and the results from these liquid simulant tests.

\subsection{Fabrication of WM-180 Simulant and Melter Feed}

Six liters of 2001 WM-180 simulant were prepared to support laboratory testing. Table 7.1 summarizes the chemicals and amounts used to fabricate the simulant (listed in order of addition). The simulant was prepared by mixing the dry salts in a beaker. Then just enough deionized water (DIW) was added to dissolve all of the salts with heating and stirring. The manganese nitrate and aluminum nitrate solutions were added to this solution. The resulting solution was continually heated and stirred as the boric acid was added. At this point, the heating and stirring were discontinued, and the solution was transferred to a plastic carboy. The hydrofluoric acid was then added to the slurry and stirred. Then the sulfuric acid was added to the slurry as it was stirred vigorously. About $1 \mathrm{~L}$ of DIW was added to the slurry, and then the hydrochloric, phosphoric, nitric, and molybdic acids were added to the slurry. Finally, DIW was added to bring the final volume of the slurry to $6 \mathrm{~L}$. The resulting slurry was then thoroughly mixed by stirring. The composition of the resulting solution was analyzed using inductively coupled plasma (ICP) and ion chromatography (IC). The average concentrations from four ICP measurements are listed in Table 7.2.

Table 7.1. Chemicals Used in the Preparation of 2001 WM-180 Simulant

\begin{tabular}{|c|c|c|c|}
\hline Chemical Used & Amount Used (g) & Chemical Used & Amount Used \\
\hline $\mathrm{NaNO}_{3}$ & 1050 & $\mathrm{RuCl}_{3}$ & $0.9674 \mathrm{~g}$ \\
\hline $\mathrm{KNO}_{3}$ & 119 & $\mathrm{Sr}\left(\mathrm{NO}_{3}\right)_{2}$ & $0.149 \mathrm{~g}$ \\
\hline $\mathrm{Ca}\left(\mathrm{NO}_{3}\right)_{2} \quad 4 \mathrm{H}_{2} \mathrm{O}$ & 66.8 & $\mathrm{TiO}_{2}$ & $0.0277 \mathrm{~g}$ \\
\hline $\mathrm{Cd}\left(\mathrm{NO}_{3}\right)_{2} \quad 4 \mathrm{H}_{2} \mathrm{O}$ & 1.4003 & $\mathrm{Zn}\left(\mathrm{NO}_{3}\right)_{2} \quad 6 \mathrm{H}_{2} \mathrm{O}$ & $1.89 \mathrm{~g}$ \\
\hline $\mathrm{Ni}\left(\mathrm{NO}_{3}\right)_{2} \quad 6 \mathrm{H}_{2} \mathrm{O}$ & 2.59 & $\mathrm{KI}$ & $0.132 \mathrm{~g}$ \\
\hline $\mathrm{Fe}\left(\mathrm{NO}_{3}\right)_{3} \quad 9 \mathrm{H}_{2} \mathrm{O}$ & 52.7 & $\mathrm{H}_{5} \mathrm{As}_{3} \mathrm{O}_{10}$ & $0.476 \mathrm{~g}$ \\
\hline $\mathrm{ZrF}_{4}$ & 0.0678 & $\mathrm{Mn}\left(\mathrm{NO}_{3}\right)_{2}(50 \%$ soln $)$ & $30.2 \mathrm{~g}$ \\
\hline $\mathrm{Cr}\left(\mathrm{NO}_{3}\right)_{3} 9 \mathrm{H}_{2} \mathrm{O}$ & 8.05 & $2.2 \mathrm{M} \mathrm{Al}\left(\mathrm{NO}_{3}\right)_{3}$ soln & $1810 \mathrm{~mL}$ \\
\hline $\mathrm{Ba}\left(\mathrm{NO}_{3}\right)_{2}$ & 0.089 & $\mathrm{H}_{3} \mathrm{BO}_{3}$ & $4.59 \mathrm{~g}$ \\
\hline $\mathrm{Ce}\left(\mathrm{NO}_{3}\right)_{3} \quad 6 \mathrm{H}_{2} \mathrm{O}$ & 0.1238 & $28.9 \mathrm{M} \mathrm{HF}$ & $7.0 \mathrm{~mL}$ \\
\hline $\mathrm{Co}\left(\mathrm{NO}_{3}\right)_{2} \quad 6 \mathrm{H}_{2} \mathrm{O}$ & 0.0337 & $18 \mathrm{M} \mathrm{H}_{2} \mathrm{SO}_{4}$ & $23.3 \mathrm{~mL}$ \\
\hline $\mathrm{Cu}\left(\mathrm{NO}_{3}\right)_{2} 3 \mathrm{H}_{2} \mathrm{O}$ & 1.013 & $12 \mathrm{M} \mathrm{HCl}$ & $14.6 \mathrm{~mL}$ \\
\hline $\mathrm{Gd}\left(\mathrm{NO}_{3}\right)_{3} 5 \mathrm{H}_{2} \mathrm{O}$ & 0.4623 & $14.6 \mathrm{M} \mathrm{H}_{3} \mathrm{PO}_{4}$ & $5.6 \mathrm{~mL}$ \\
\hline $\mathrm{Pb}\left(\mathrm{NO}_{3}\right)_{2}$ & 2.4057 & $15.4 \mathrm{M} \mathrm{HNO}_{3}$ & $197 \mathrm{~mL}$ \\
\hline $\mathrm{LiNO}_{3}$ & 0.14 & $\mathrm{H}_{2} \mathrm{MoO}_{4}$ & $0.2 \mathrm{~g}$ \\
\hline $\mathrm{Mg}\left(\mathrm{NO}_{3}\right)_{2} \quad 6 \mathrm{H}_{2} \mathrm{O}$ & 18.51 & $15.4 \mathrm{M} \mathrm{HNO}_{3}$ & $113 \mathrm{~mL}$ \\
\hline
\end{tabular}


Table 7.2. Chemical Analysis of SBW Simulant

\begin{tabular}{|c|c|c|c|c|c|c|c|}
\hline Element & $\begin{array}{c}\text { Target } \\
\text { Concentration } \\
(\mathrm{g} / \mathrm{mL})\end{array}$ & $\begin{array}{c}\text { Analyzed } \\
\text { Concentration } \\
(\mathrm{g} / \mathrm{mL})\end{array}$ & $\begin{array}{c}\% \\
\text { Difference }\end{array}$ & Element & $\begin{array}{c}\text { Target } \\
\text { Concentration } \\
(\mathrm{g} / \mathrm{mL})\end{array}$ & $\begin{array}{c}\text { Analyzed } \\
\text { Concentration } \\
(\mathrm{g} / \mathrm{mL})\end{array}$ & $\begin{array}{c}\% \\
\text { Difference }\end{array}$ \\
\hline $\mathrm{Al}$ & 17,897 & 15,800 & -12 & $\mathrm{~K}$ & 7,669 & 6,600 & -14 \\
\hline As & 18.69 & $*$ & & $\mathrm{Li}$ & 2.355 & 3.60 & 53 \\
\hline $\mathrm{B}$ & 133.0 & 130 & -2 & $\mathrm{Mg}$ & 292.4 & 295 & 1 \\
\hline $\mathrm{Ba}$ & 7.656 & 5.65 & -26 & $\mathrm{Mn}$ & 774.6 & 810 & 5 \\
\hline $\mathrm{Ca}$ & 1,891 & 1,600 & -15 & Mo & 18.49 & * & \\
\hline $\mathrm{Cd}$ & 84.76 & 81 & -4 & $\mathrm{Na}$ & 47,308 & 42,000 & -11 \\
\hline $\mathrm{Ce}$ & 6.625 & $*$ & & $\mathrm{Ni}$ & 86.35 & 78.0 & -10 \\
\hline $\mathrm{Cl}$ & 1,042 & $*$ & & $\mathrm{P}$ & 424.4 & 680 & 60 \\
\hline Co & 1.135 & $*$ & & $\mathrm{~Pb}$ & 270.8 & 340 & 26 \\
\hline $\mathrm{Cr}$ & 174.3 & 170 & -2 & $\mathrm{Ru}$ & 79.61 & $*$ & \\
\hline $\mathrm{Cu}$ & 44.29 & 46.0 & 4 & $S$ & 2,238 & 2,200 & -2 \\
\hline $\mathrm{F}$ & 648.4 & $*$ & & $\mathrm{Sr}$ & 10.44 & 14.0 & 34 \\
\hline$\overline{\mathrm{Fe}}$ & 1,214 & 1,100 & -9 & $\mathrm{Ti}$ & 2.767 & * & \\
\hline $\mathrm{Gd}$ & 27.87 & $*$ & & $\mathrm{Zn}$ & 68.60 & * & \\
\hline $\mathrm{I}$ & 16.48 & $*$ & & $\mathrm{Zr}$ & 6.044 & * & \\
\hline
\end{tabular}

A slurried melter feed is fabricated from the simulant with the addition of glass-forming chemicals (GFCs) (summarized in Table 7.3), sugar and/or other reductants, extra water and/or $\mathrm{HNO}_{3}$ (to obtain acceptable slurry flow properties), and $\mathrm{H}_{2} \mathrm{SO}_{4}$ to adjust the target concentration of $\mathrm{SO}_{3}$ in the glass. Sufficient slurry feed to fabricate between 50 and $200 \mathrm{~g}$ of glass was developed with most feeds designed to fabricate either 50 or $85 \mathrm{~g}$ of glass. The GFCs were each weighed in the proper proportions and then slowly stirred into the waste simulant in a beaker on a stir plate. When $\mathrm{HNO}_{3}$ was used to obtain better flow properties, it was added before adding the GFCs. When water was added to obtain better flow properties, it was added after adding the GFCs. In later tests, the GFCs were premelted into a frit (either all GFCs or partial mixtures) as will be described below.

Table 7.3. Chemical Sources for Glass-Forming Additives

\begin{tabular}{||l|l|l||}
\hline Glass Component & Typical Source Chemical & Alternative Chemical \\
\hline $\mathrm{B}_{2} \mathrm{O}_{3}$ & $\mathrm{H}_{3} \mathrm{BO}_{3}$ & \\
\hline $\mathrm{CaO}$ & $\mathrm{CaCO}_{3}$ & $\mathrm{Ca}(\mathrm{OH})_{2}$ \\
\hline $\mathrm{Fe}_{2} \mathrm{O}_{3}$ & $\mathrm{Fe}_{2} \mathrm{O}_{3}$ & \\
\hline $\mathrm{K}_{2} \mathrm{O}$ & $\mathrm{K}_{2} \mathrm{CO}_{3}$ & \\
\hline $\mathrm{Li}{ }_{2} \mathrm{O}$ & $\mathrm{Li}_{2} \mathrm{CO}_{3}$ & $\mathrm{LiOH} \cdot \mathrm{H}_{2} \mathrm{O}$ \\
\hline $\mathrm{MgO}$ & $\mathrm{MgO}$ & $\mathrm{Mg}(\mathrm{OH})_{2}$ \\
\hline $\mathrm{Na}_{2} \mathrm{O}$ & $\mathrm{Na}_{2} \mathrm{CO}_{3}$ & $\mathrm{NaOH}$ \\
\hline $\mathrm{SiO}_{2}$ & $\mathrm{SiO}_{2}(-240$ mesh $)$ & \\
\hline $\mathrm{V}_{2} \mathrm{O}_{5}$ & $\mathrm{~V}_{2} \mathrm{O}_{5}$ & \\
\hline $\mathrm{ZrO}_{2}$ & $\mathrm{ZrO}_{2}(-325$ mesh $)$ & \\
\hline
\end{tabular}




\subsection{Summary of Ramp Heated Crucible Melts}

Ramp-heating crucible melts were performed that were based on SBW-1, -2, -4, -9, -10, and -22 additive compositions. The tests with SBW-2, -4 , and -9 used 2000 WM-180 simulant, and the tests with SBW-22 used 2001 WM-180 simulant. The goals of these tests were to determine the appropriate WL, the need for any acid additions or adjustments, and the appropriate additive compositions. Most of the tests were performed using two basic test methods. In the first set of experiments (referred to as Method 1), all melts were made by mixing enough waste simulant and additives to obtain $50 \mathrm{~g}$ of glass (after loss of all $\mathrm{H}_{2} \mathrm{O}, \mathrm{HNO}_{3}, \mathrm{C}_{6} \mathrm{H}_{12} \mathrm{O}_{6}$, and other volatile components). The dry additives were slowly mixed into the waste simulant in either the melting crucible $(\sim 500 \mathrm{~mL}$ alumina crucibles) or Teflon beakers with a Teflon-coated stir bar. Sugar was added to the mixture along with other solid additives. In many cases, concentrated $\mathrm{HNO}_{3}$ was added using a pipette to adjust the total $\mathrm{pH}$ after solids were added. The mixtures were heated on a hot plate with continued stirring using a hot-plate face temperature of roughly $140^{\circ} \mathrm{C}$ until nearly dry. The mixtures were transferred to drying ovens to dry overnight ( $\left.16 \mathrm{~h}\right)$ at roughly $100^{\circ} \mathrm{C}$. For samples dried directly in alumina crucibles, the tight-fitting crucible lids were coated with a glass frit and placed on the crucible in the heat-treatment furnace. For samples dried in Teflon beakers, the sample was first transferred to a high-SiO $2(>98 \%)$ crucible. Heat treatments were performed by ramp heating from between room temperature and $150^{\circ} \mathrm{C}$ to $240^{\circ} \mathrm{C}$ at $3^{\circ} \mathrm{C} / \mathrm{min}$, from $240^{\circ} \mathrm{C}$ to 300 at $1{ }^{\circ} \mathrm{C} / \mathrm{min}$, and then from $300^{\circ} \mathrm{C}$ to $1150^{\circ} \mathrm{C}$ at $6^{\circ} \mathrm{C} / \mathrm{min}$, held at $1150^{\circ} \mathrm{C}$ for $1 \mathrm{~h}$, and quenched to room temperature. The lid was removed from the crucible (usually by breaking it off), and visual observations of the melt were made. A 20-mL sample of DIW was used to wash any salt off the top of the melt/crucible interior. The salt solutions were analyzed using inductively coupled plasma-optical emission spectrometry (ICPOES) and/or IC. Glass samples were broken from the crucible and ground to roughly 1- $\mu$ m median particle diameter in a tungsten-carbide mill. Glass powder (and occasionally dry feed samples) were fused in $\mathrm{Na}_{2} \mathrm{O}_{2}$ and $\mathrm{KOH}$, dissolved in $\mathrm{HNO}_{3}$, and analyzed by ICP-OES. The $\mathrm{S}$ concentration of glass samples was also analyzed by X-ray fluorescence spectroscopy (XRF).

The second set of tests (Method 2) was also performed with the 2000 WM-180 simulant, but differed slightly in the experimental procedure relative to Method 1. In this second set of tests, all melts were made by mixing $150 \mathrm{~mL}$ of waste simulant, which required varying quantities of additives to target between 40 to $60 \mathrm{~g}$ of glass. The dry additives were slowly mixed into the waste simulant in the melting crucible ( $\sim 00 \mathrm{~mL} \mathrm{Pt} / \mathrm{Au}$ crucibles) for all tests. The sugar was added to the mixture along with other solid additives. In many cases, a predetermined quantity of concentrated $\mathrm{HNO}_{3}$ was added using a pipette to adjust the total $\mathrm{pH}$ to that of the simulant before adding solids. The mixtures were heated on a hot plate with continued stirring using a hot-plate face temperature of roughly $140^{\circ} \mathrm{C}$ until nearly dry (during drying, a Pt/Au lid was placed on top of the crucible). The mixtures were transferred to a hightemperature furnace to dry. The furnace was then ramped at $\sim 8^{\circ} \mathrm{C} / \mathrm{min}$ to $150^{\circ} \mathrm{C}$ and held for $20 \mathrm{~min}$ and then to $225^{\circ} \mathrm{C}$ and held for $20 \mathrm{~min}$. For select tests, a dry sample was obtained at this point for ICP and IC analysis. The furnace was then ramped at $8^{\circ} \mathrm{C} / \mathrm{min}$ to $1150^{\circ} \mathrm{C}$ and then held for $1 \mathrm{~h}$. The crucible was removed and placed in a pan of water. No lid was used during vitrification. Visual observations of the melt were made during heating. Glass samples were broken from the crucible and analyzed by ICP-OES. Other samples were taken for various property testing.

The results of crucible tests with SBW-1, -2, -4, -9, and -10 were reported by Peeler et al. 2001 and are partially repeated here along with results from tests with SBW-22, 2001 WM-180 simulant, using Method 1. Table 7.4 summarizes the tests performed and their results. 
Table 7.4. Parameters, Visual Observations, and Results for the Liquid Simulant Crucible Tests

\begin{tabular}{|c|c|c|c|c|c|c|c|c|}
\hline Glass & $\begin{array}{c}\text { WL } \\
(\operatorname{mass} \%)\end{array}$ & $\begin{array}{c}\text { Sugar } \\
(\mathrm{g} / \mathrm{L})\end{array}$ & $\begin{array}{c}\text { Target } \\
\mathrm{SO}_{3} \\
\end{array}$ & Test & Salt $^{(\mathbf{a})}$ & $\begin{array}{l}\text { S in } \\
\text { Salt } \\
(\text { (g) })^{(\mathbf{b})}\end{array}$ & $\begin{array}{l}\mathrm{SO}_{3} \text { in } \\
\text { Glass } \\
(\%)^{(\mathbf{b})}\end{array}$ & Comments \\
\hline SBW-1 & 25 & 141 & 0.89 & 2 & 3 & NM & NM & --- \\
\hline SBW-4 & 20 & 141 & 0.71 & 2 & No & NM & NM & --- \\
\hline SBW-4 & 25 & 141 & 0.89 & 2 & No & NM & NM & --- \\
\hline SBW-4 & 25 & 141 & 0.89 & 2 & No & NM & NM & $2 \mathrm{M} \mathrm{H}^{+}$ \\
\hline SBW-4 & 30 & 141 & 1.07 & 2 & 4 & NM & NM & XRD and SEM/EDS Results \\
\hline SBW-4 & 30 & 141 & 1.07 & 2 & 4 & NM & NM & $2 \mathrm{M} \mathrm{H}^{+}$ \\
\hline SBW-4 & 30 & 141 & 1.07 & 2 & 4 & NM & NM & $3 \mathrm{M} \mathrm{H}^{+}$ \\
\hline SBW-4 & 35 & 0 & 1.25 & 2 & 2 & NM & NM & --- \\
\hline SBW-4 & 35 & 141 & 1.31 & 2 & 4 & NM & NM & $2 \underline{\mathrm{M} \mathrm{H}^{+}, 1999 \mathrm{SBW}}$ \\
\hline SBW-9 & 25 & 141 & 0.89 & 2 & No & NM & NM & --- \\
\hline SBW-9 & 25 & 141 & 0.89 & 2 & No & NM & NM & --- \\
\hline SBW-9 & 30 & 141 & 1.07 & 2 & No & NM & NM & --- \\
\hline SBW-9 & 30 & 141 & 1.07 & 2 & 1 & NM & NM & $2 \mathrm{M} \mathrm{H}^{+}$ \\
\hline SBW-10 & 30 & 141 & 1.07 & 2 & 3 & NM & NM & $2 \mathrm{M} \mathrm{H}^{+}, \mathrm{SBW}-4$ with $\mathrm{BaO}$ for $\mathrm{CaO}$ \\
\hline SBW-2 & 35 & 77 & 1.25 & 1 & 4 & .082 & NM & Sugar test FeII $/ \mathrm{Fe}=7.07 \times 10^{-4}$ \\
\hline SBW-2 & 35 & 109 & 1.25 & 1 & 4 & .093 & NM & Sugar test FeII $/ \mathrm{Fe}=3.86 \times 10^{-4}$ \\
\hline SBW-2 & 35 & 131 & 1.25 & 1 & 4 & .094 & NM & Sugar test FeII $/ \mathrm{Fe}=1.32 \times 10^{-3}$ \\
\hline SBW-2 & 35 & 164 & 1.25 & 1 & 3 & .093 & NM & Sugar test FeII $/ \mathrm{Fe}=2.71 \times 10^{-1}$ \\
\hline SBW-4Q & 35 & 141 & 1.25 & other & $\mathrm{N} / \mathrm{a}$ & .002 & 0.80 & $2.5 \mathrm{~g} \mathrm{Q}$-furnace test \\
\hline SBW-4D & 35 & 141 & 1.25 & other & 4 & NM & NM & Dryout test \\
\hline SBW-4D & 35 & 141 & 1.25 & other & 2 & NM & NM & $3 \mathrm{M} \mathrm{H}^{+}$, Dryout test \\
\hline SBW-4 & 35 & 141 & 1.25 & 1 & 3 & .048 & 0.98 & $2 \underline{\mathrm{M} \mathrm{H}}{ }^{+}$, Acid adjustment \\
\hline SBW-4 & 35 & 141 & 1.25 & 1 & 3 & .038 & 0.98 & $3 \mathrm{M} \mathrm{H}^{+}$, Acid adjustment \\
\hline SBW-9 & 30 & 141 & 1.07 & 1 & 1 & .003 & 1.1 & $2.1 \mathrm{M} \mathrm{H}^{+}$ \\
\hline SBW-9 & 30 & 141 & 1.07 & 1 & 1 & NM & NM & $2.1 \mathrm{M} \mathrm{H}^{+}$ \\
\hline SBW-9 & 30 & 141 & 1.07 & 1 & 1 & .025 & 0.85 & --- \\
\hline SBW-9 & 25 & 141 & 0.89 & 1 & 2 & .019 & 0.78 & --- \\
\hline SBW-9 & 25 & 141 & 0.89 & 1 & 3 & NM & NM & -- \\
\hline SBW-9 & 28 & 141 & 1.00 & 1 & 3 & NM & NM & --- \\
\hline SBW-9 & 32 & 141 & 1.14 & 1 & 3 & NM & NM & --- \\
\hline SBW-9 & 32 & 135 & 1.14 & other & No & NM & 0.43 & oven dried in $\mathrm{Al}_{2} \mathrm{O}_{3}$ cruc, $5 \mathrm{cf} / \mathrm{h} \mathrm{N}_{2}$ sweep gas \\
\hline SBW-9 & 32 & 135 & 1.14 & other & No & NM & 0.23 & $5 \mathrm{cf} / \mathrm{h} \mathrm{N} \mathrm{N}_{2}$ sweep gas \\
\hline SBW-9 & 32 & 135 & 1.14 & other & No & NM & 0.15 & $\begin{array}{l}\mathrm{Pt} \text { cruc, } 5 \mathrm{cf} / \mathrm{h} \mathrm{N}_{2} \text { sweep gas fast/exothermic } \\
\text { reaction near completion of drying }\end{array}$ \\
\hline SBW-22 & 20 & 160 & 0.91 & 1 & No & NM & 0.84 & --- \\
\hline SBW-22 & 22.5 & 160 & 1.02 & 1 & No & NM & 1.00 & --- \\
\hline SBW-22 & 25 & 160 & 1.14 & 1 & 1 & NM & 1.01 & faint "finger-print" of salt on surface \\
\hline \multicolumn{9}{|c|}{$\begin{array}{l}\text { (a) Salt - 1) faint patterns on surface, 2) hazy patterns cover surface, 3) accumulation of salt in areas, } \\
\text { 4) gross accumulation of salt. } \\
\text { (b) NM - Not measured. }\end{array}$} \\
\hline
\end{tabular}


Table 7.5 summarizes the matrix of CSM tests performed. The CSM tests were performed in three series. The first series of tests was aimed at determining the effects of different physical and chemical parameters on the partitioning of sulfur between glass, off-gas, and salt phases. This series of tests; performed with SBW-9 based additive mixes (composed of carbonate and oxide source chemicals) and 2000 WM-180 simulant; varied feed rate, free acid, sugar content, reductant type, and $\mathrm{SO}_{3}$ content. The results from the initial series of tests (CSM041201 through CSM070901) are summarized by Darab et al. (2001) and are partially repeated in this report.

The second series of tests was aimed at determining the influence of additive composition on partitioning of sulfur between the glass, off-gas, and salt phases. This series of tests (CSM070501 through CSM080901) based on 2001 WM-180 simulant varied additive composition and $\mathrm{SO}_{3}$ content. The results of these tests along with other tests described in this report narrowed the baseline additive composition to SBW-22 and the baseline $2001 \mathrm{WM}-180$ concentration to 20 mass\% on a glass oxide basis.

The third series of tests was aimed at understanding the effects of additive source chemical addition on sulfur behavior. This series of tests (CSM110601 through CSM011102), based on SBW-22 additive composition using $2001 \mathrm{WM}-180$ simulant at $20 \% \mathrm{WL}$, varied sugar content, $\mathrm{HNO}_{3}$ addition, and chemical form of additives. The chemical form variants included additives comprised of oxide and carbonates, oxides and hydroxides, and full and partial frits. Since the feeds based on GFCs required the addition of water or $\mathrm{HNO}_{3}$ to obtain acceptable rheology, $\mathrm{HNO}_{3}$ and sugar concentrations were also systematically varied.

\subsection{CSM Experimental Method}

The centimeter scale melter (CSM) was developed to better simulate those processes that are important to determining the behavior of sulfur in a slurry-fed melter system with batch heating from the glass melt below (Darab et al. 2001). Figure 7.1 shows a schematic diagram of the CSM used for the study of WM-180 simulant vitrification in the laboratory. The steps and conditions used in CSM testing are described below. 
Table 7.5. Summary of CSM Tests Performed

\begin{tabular}{|c|c|c|c|c|c|c|c|c|c|}
\hline Set & $\overline{\text { Test ID }^{(\mathbf{a})}}$ & Glass & $\overline{\text { Sim }^{(\mathbf{b})}}$ & WWL & $\overline{\mathrm{SO}_{3}{ }^{(\mathrm{c})}}$ & $\mathrm{HNO}_{3}{ }^{(\mathrm{d})}$ & Sugar $^{(\mathrm{e})}$ & Rate $^{(f)}$ & Comment \\
\hline \begin{tabular}{|l|l|}
1 & \\
\end{tabular} & 041201 & 9 & 2000 & 32 & 1.14 & --- & 135 & 0.8 & Base run \\
\hline 1 & 042701 & 9 & 2000 & 32 & 1.14 & --- & 135 & 1.5 & Base run \\
\hline 1 & 050801 & 9 & 2000 & 32 & 1.14 & --- & 135 & 1.5 & $\begin{array}{l}\text { High sweep gas rate } \\
\end{array}$ \\
\hline 1 & 051401 & 9 & 2000 & 32 & 1.14 & --- & 135 & 7.2 & High feed rate \\
\hline 1 & 051601 & 9 & 2000 & 32 & 2.28 & --- & 135 & 1.3 & $200 \% \mathrm{~S}$ as $\mathrm{Na}_{2} \mathrm{SO}_{4}$ \\
\hline 1 & 052401 & 9 & 2000 & 32 & 1.14 & 111 & 135 & 1.5 & $240 \% \mathrm{H}^{+}$ \\
\hline 1 & 053101 & 9 & 2000 & 32 & 1.14 & -- & --- & 1.3 & \begin{tabular}{|l} 
No sugar \\
\end{tabular} \\
\hline 1 & 060101 & 9 & 2000 & 32 & 1.14 & --- & 135 & 0.5 & Low feed rate \\
\hline 1 & 060501 & 9 & 2000 & 32 & 1.14 & --- & 135 & 0.8 & Low feed rate \\
\hline 1 & 060601 & 9 & 2000 & 32 & 1.14 & --- & 75 & 1.3 & $50 \%$ sugar \\
\hline 1 & 060801 & 9 & 2000 & 32 & 1.14 & --- & 203 & 1.3 & $150 \%$ sugar \\
\hline 1 & 061201 & 9 & 2000 & 32 & 1.14 & --- & --- & 1.3 & $83 \% \mathrm{C}$ as glycolic acid $(13.39 \mathrm{~g})$ \\
\hline 1 & 061401 & 9 & 2000 & 32 & 1.14 & 101 & 135 & 1.3 & $200 \% \mathrm{H}^{+}$ \\
\hline 1 & 061801 & 9 & 2000 & 32 & 1.14 & $-\ldots$ & 68 & 1.3 & $50 \%$ C from urea, $50 \% \mathrm{C}$ from sugar \\
\hline 1 & 062101 & 9 & 2000 & 32 & 1.14 & $\overline{----}$ & 135 & 1.3 & Base run, $\mathrm{SO}_{2}$ spike in off-gas \\
\hline 1 & 062201 & 9 & 2000 & 32 & 1.14 & --- & 135 & 1.3 & Long run (200 mL feed) \\
\hline 1 & 062601 & 9 & 2000 & 32 & 1.14 & 166 & 203 & 1.3 & $150 \%$ sugar, $150 \% \mathrm{HNO}_{3}$ \\
\hline 1 & 062701 & 9 & 2000 & 32 & 1.14 & --- & 135 & 1.3 & Base run, $\mathrm{SO}_{2}$ spike in off-gas \\
\hline 1 & 070901 & 9 & 2000 & 32 & 1.14 & --- & --- & 1.3 & $100 \% \mathrm{C}$ (as $16.2 \mathrm{~g}$ glycolic acid) \\
\hline 2 & 070501 & 11 & 2001 & 18.2 & 0.80 & --- & 140 & 1.3 & $\mathrm{H}_{2} \mathrm{O}$ added for rheology \\
\hline 2 & 071001 & 11 & 2001 & 18.5 & 1.20 & --- & 140 & 1.3 & $\mathrm{H}_{2} \mathrm{O}$ added for rheology \\
\hline 2 & 071101 & 11 & 2001 & \begin{tabular}{|l|}
18.5 \\
\end{tabular} & 1.40 & --- & 140 & 1.3 & $\mathrm{H}_{2} \mathrm{O}$ added for rheology \\
\hline 2 & 071301 & 22 & 2001 & 20 & 1.40 & 63 & 168 & 1.3 & $-\ldots$ \\
\hline 2 & 072001 & 22 & 2001 & 20 & 1.80 & 60 & 164 & 1.3 & --- \\
\hline 2 & 072301 & 24 & 2001 & 20 & 1.80 & 60 & 164 & 1.3 & --- \\
\hline 2 & 072401 & 23 & 2001 & 20 & 1.80 & 60 & 164 & 1.3 & -- \\
\hline 2 & 072501 & 25 & 2001 & 20 & 1.80 & 60 & 164 & 1.3 & --- \\
\hline 2 & 072601 & 26 & 2001 & 20 & 1.80 & 60 & 164 & 1.3 & --- \\
\hline 2 & 080901 & 27 & 2001 & 20 & 1.80 & 60 & 164 & 1.3 & --- \\
\hline 3 & 110601 & 22 & 2001 & 20 & \begin{tabular}{|l|}
0.91 \\
\end{tabular} & 100 & 207 & 1.5 & carbonates, high sugar \\
\hline 3 & 110801 & 22 & 2001 & 20 & \begin{tabular}{|l|l|}
0.91 \\
\end{tabular} & 100 & 207 & 1.9 & hydroxides, high sugar \\
\hline 3 & 111201 & 22 & 2001 & 20 & \begin{tabular}{|l|}
0.91 \\
\end{tabular} & 100 & 207 & 1.5 & \begin{tabular}{|l} 
frit, high sugar \\
\end{tabular} \\
\hline 3 & 111301 & 22 & 2001 & 20 & \begin{tabular}{|l|}
0.91 \\
\end{tabular} & --- & 160 & 2.8 & frit, med sugar \\
\hline 3 & 111401 & 22 & 2001 & 20 & 0.91 & 100 & 207 & 1.5 & frit, high sugar \\
\hline 3 & 111601 & 22 & 2001 & 20 & 0.91 & --- & 160 & 1.5 & frit, med sugar \\
\hline 3 & 121201 & 22 & 2001 & 20 & 0.91 & 100 & 160 & 1.5 & hydroxides, med sugar \\
\hline 3 & 121301 & 22 & 2001 & 20 & 1.80 & --- & 160 & 1.5 & frit, med sugar, high S \\
\hline 3 & 121401 & 22 & 2001 & 20 & 0.91 & 100 & 160 & 1.5 & frit, med sugar \\
\hline 3 & 122101 & 22 & 2001 & 20 & 0.91 & 100 & 160 & --- & hydroxides, med sugar, variable feed rate \\
\hline 3 & 010402 & 22 & 2001 & 20 & 0.91 & 100 & 127 & 2.4 & hydroxides, low sugar \\
\hline 3 & 010802 & 22 & 2001 & 20 & 0.91 & --- & 51 & 2.0 & frit, low sugar \\
\hline 3 & 010902 & 22 & 2001 & 20 & \begin{tabular}{|l|}
0.91 \\
\end{tabular} & $-\overline{-}$ & 51 & 2.3 & frit $(-\mathrm{Ca},-\mathrm{V})$, low sugar \\
\hline 3 & 011002 & 22 & 2001 & 20 & 0.91 & --- & 51 & 2.4 & frit $(-V)$, low sugar \\
\hline 3 & 011102 & 22 & 2001 & 20 & 0.91 & --- & 51 & 2.2 & frit (-Ca), low sugar \\
\hline (a) & \multicolumn{9}{|c|}{ Test identification numbers are CSMxxxxxx, where xxxxxx represents the date of the test. } \\
\hline (b) & \multicolumn{9}{|c|}{ CSM test simulants include 2000 WM-180 (2000) and 2001 WM-180 (2001) described in Table 2.1. } \\
\hline (c) & \multicolumn{9}{|c|}{$\mathrm{SO}_{3}$ is the concentration of sulfur targeted in the final glass (assuming no loss) on a mass $\% \mathrm{SO}_{3}$ basis. } \\
\hline (d) & \multicolumn{9}{|c|}{$\begin{array}{l}\mathrm{HNO}_{3} \text { is the amount of concentrated nitric acid added to the feed prior to the test on a mili-liter nitric } \\
\text { acid/L original SBW simulant basis. }\end{array}$} \\
\hline (e) & \multicolumn{9}{|c|}{$\begin{array}{l}\text { Sugar is the concentration of sucrose added to the feed on a grams of sucrose/L of original SBW } \\
\text { simulant basis }\end{array}$} \\
\hline (f) & \multicolumn{9}{|c|}{$\begin{array}{l}\text { Rate is the slurry feed rate to the CSM on a mili-liter per minute basis. All tests described here were run } \\
\text { in the } 1 \text { inch diameter CSM }\left(5.07 \times 10^{-4} \mathrm{~m}^{2}\right) \text { so the specific feed rate in } \mathrm{L} \cdot \mathrm{min}^{-1} \cdot \mathrm{m}^{-2} \text { is rate } \times 1.974 \text {. }\end{array}$} \\
\hline
\end{tabular}




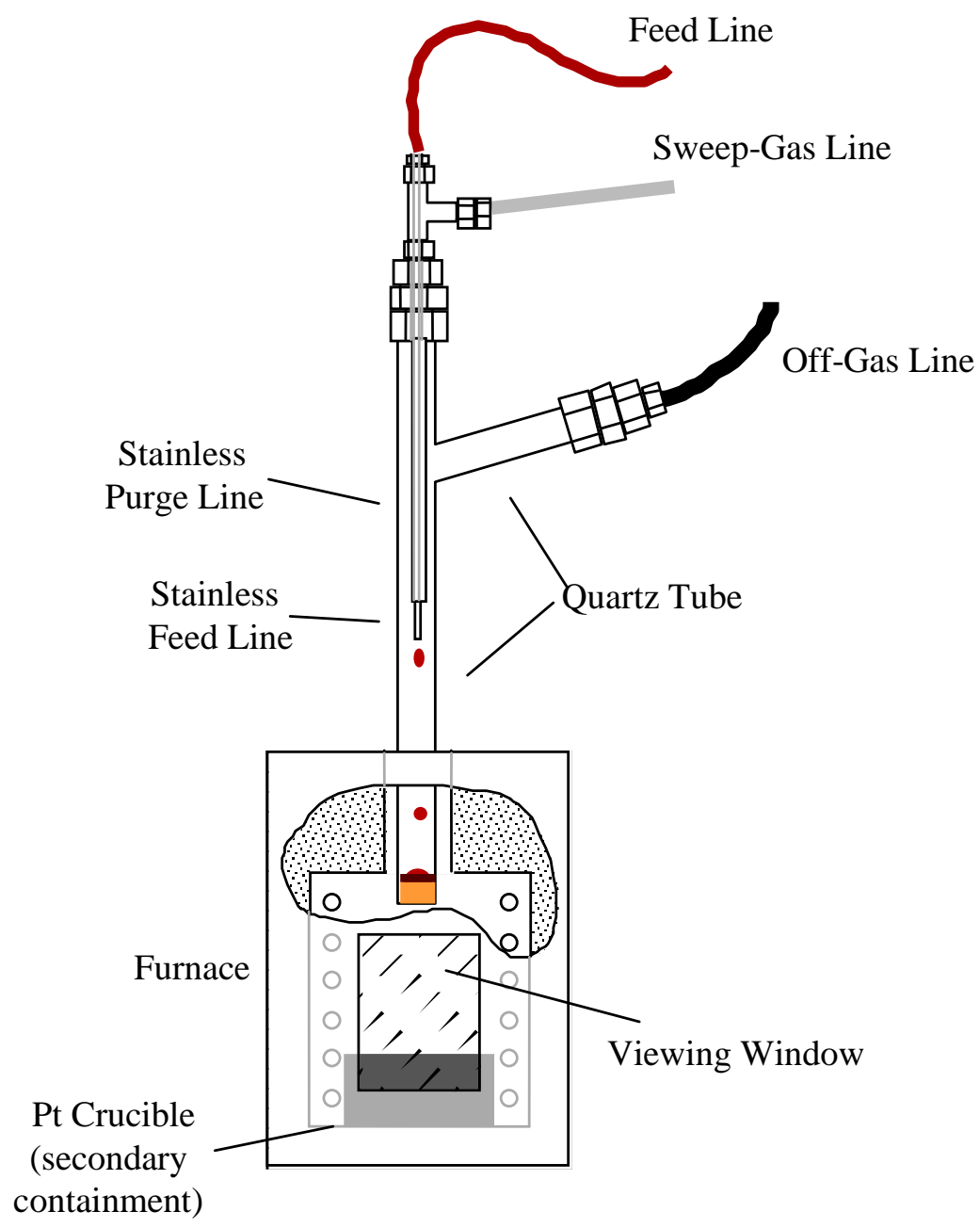

Figure 7.1. Schematic Diagram of the CSM. Typically, the quartz tube assembly is gradually lowered further into the furnace as the melt level increases with time. For clarity, a cut-away view of part of the furnace is shown.

The CSM consists of a main vessel of 1-in.-diameter fused-silica tubing as shown in Figure 7.1. ${ }^{\text {(a) }}$ This tubing is sealed at the bottom, open at the top, and has a side-arm near the top for gas removal. The tube is suspended in a custom-designed box furnace equipped with a fused-silica window to observe the experiment. The melter feed is introduced through the top of the crucible through an $1 / 8$-in. stainless steel tube that extends past the off-gas side-arm and is roughly centered in the crucible. The feed tube is surrounded by a sweep-gas flow tube that delivers roughly 50 to $100 \mathrm{ccm}$ of helium to facilitate delivery of the gasses generated by the experiment to the off-gas analysis system. The off-gas treatment/analyses were performed using a number of different setups (described by Darab et al. 2001 in detail). Typically, gases exiting the side-arm went into a submerged bed scrubber, through a water-cooled condenser, and into a gas-chromatograph with a mass spectrometer (GC-MS). During the experiment, the concentrations

(a) Later CSM designs include 1.5- and 3-in.-diameter crucible tubes that flare out from the main interface tube just below the feed tube. 
of several fixed gasses were measured using the GC-MS. After each experiment was completed, each of the gas lines was flushed, and the resulting solution was combined with the scrubber solution and condensate for analyses. The combined solutions were analyzed by ICP-AES and IC. The glasses resulting from the testing were analyzed by fusion and dissolution followed by ICP-AES and/or directly by XRF.

To perform the CSM tests, slurried melter feed was stirred in a beaker on a stir-plate. A Tygon ${ }^{\circledR}$ tube was used to draw the feed directly from the beaker, through a systolic pump, and to the $1 / 8$-in. stainless steel feed tube at a desired rate. The feed drops from the feed tube to the melt surface where it is heated from the glass melt below. Although the plenum temperature is not controlled, the crucible can be placed fully into the furnace (which is typically held at $1150^{\circ} \mathrm{C}$ ) or more typically, adjusted so that the glassmelt/cold-cap interface is maintained at the furnace hot-zone chamber-top refractory interface to assure that the primary source of heat to the melting batch comes from the glass melt pool below.

\subsection{CSM Results}

The results from the first series of CSM tests are reported by Darab et al. (2001). We repeat many of those results here but primarily focus on the second two series of glasses. Table 7.6 summarizes the sulfur partitioning between the off-gas scrub solution, glass, and salt for the CSM tests listed in Table 7.5.

Of direct importance to formulating a glass for scaled melter testing with SBW is the partitioning of sulfur between the off-gas, glass, and salt. Of the set of three tests (i.e., SBW-11, -22, -23, -24, -25, -26, and -27), only SBW-22 and -27 were able to process with 1.8 mass $\% \mathrm{SO}_{3}$ without the formation of a salt phase. From these two tests, SBW-22 had slightly higher sulfur in the glass and slightly lower sulfur in the scrub solution. However, these differences were not significant. In comparison, SBW-9 formed a salt in most tests with 1.14 mass\% $\mathrm{SO}_{3}$. Since SBW-22-based glass was fully characterized while SBW-27based glasses were not, and all other results appeared to be nearly equal, SBW-22 was chosen for further testing. 
Table 7.6. Summary of CSM Test Results

\begin{tabular}{|c|c|c|c|c|c|c|c|c|c|c|c|}
\hline \multirow[b]{2}{*}{ Set } & \multirow[b]{2}{*}{ Test } & \multirow[b]{2}{*}{ Glass } & \multirow[b]{2}{*}{ WL } & \multirow[b]{2}{*}{ Comment } & \multirow[b]{2}{*}{$\% \mathrm{SO}_{3}$ in Glass } & \multirow[b]{2}{*}{ Salt } & \multicolumn{4}{|c|}{ Fraction of S Found in Each } & \multirow[b]{2}{*}{$\mathrm{Fe}^{\mathrm{II}} / \mathrm{Fe}$} \\
\hline & & & & & & & Glass & Scrub & Salt & Sum & \\
\hline 1 & 041201 & 9 & 32 & Base run & 0.84 & 1 & $\mathrm{NA}^{(\mathrm{a})}$ & $\mathrm{NA}$ & NA & NA & NA \\
\hline 1 & 042701 & 9 & 32 & Base run & 0.84 & 0.5 & 0.73 & 0.26 & 0.01 & 1.00 & 0.07 \\
\hline 1 & 050801 & 9 & 32 & High sweep gas rate & 0.77 & 1.5 & NA & NA & NA & NA & 0.00 \\
\hline 1 & 051401 & 9 & 32 & High feed rate & 0.81 & 4 & 0.71 & 0.45 & 0.16 & 1.31 & 0.03 \\
\hline 1 & 051601 & 9 & 32 & $200 \% \mathrm{~S}$ as $\mathrm{Na}_{2} \mathrm{SO}_{4}$ & 0.96 & 2 & $\mathrm{NA}$ & NA & NA & NA & 0.00 \\
\hline 1 & 052401 & 9 & 32 & $240 \% \mathrm{H}^{+}$ & 0.81 & 0 & 0.70 & 0.15 & 0.00 & 0.85 & 0.21 \\
\hline 1 & 053101 & 9 & 32 & No sugar & 1.14 & 1 & 1.00 & NA & NA & 1.00 & 0.10 \\
\hline 1 & 060101 & 9 & 32 & Low feed rate & 1.06 & 1 & 0.93 & $\mathrm{NA}$ & NA & 0.93 & 0.08 \\
\hline 1 & 060501 & 9 & 32 & Low feed rate & $\mathrm{NA}$ & 0 & NA & NA & NA & NA & NA \\
\hline 1 & 060601 & 9 & 32 & $50 \%$ sugar & 1.10 & 1 & 0.96 & 0.21 & 0.02 & 1.18 & 0.02 \\
\hline 1 & 060801 & 9 & 32 & $150 \%$ sugar & 0.35 & 0 & 0.31 & 0.54 & NA & 0.85 & 0.80 \\
\hline 1 & 061201 & 9 & 32 & $83 \% \mathrm{C}$ as glycolic acid $(13.39 \mathrm{~g})$ & 0.85 & 1 & 0.74 & 0.24 & 0.00 & 0.99 & 0.01 \\
\hline 1 & 061401 & 9 & 32 & $200 \% \mathrm{H}^{+}$ & 0.88 & 0 & 0.77 & 0.21 & NA & 0.98 & 0.06 \\
\hline 1 & 061801 & 9 & 32 & $50 \% \mathrm{C}$ from urea, $50 \% \mathrm{C}$ from sugar & 0.45 & 1 & 0.40 & NA & NA & 0.40 & 0.30 \\
\hline 1 & 062101 & 9 & 32 & Base run, $\mathrm{SO}_{2}$ spike in off-gas & 0.71 & 0.5 & 0.62 & 0.26 & NA & 0.88 & 0.12 \\
\hline 1 & 062201 & 9 & 32 & Long run $(200 \mathrm{~mL}$ feed $)$ & 0.85 & 1 & 0.74 & 0.20 & 0.00 & 0.94 & 0.10 \\
\hline 1 & 062601 & 9 & 32 & $150 \%$ sugar, $150 \% \mathrm{HNO}_{3}$ & 0.58 & 0 & 0.50 & 0.21 & NA & 0.71 & 0.49 \\
\hline 1 & 062701 & 9 & 32 & Base run, $\mathrm{SO}_{2}$ spike in off-gas & NA & NA & NA & NA & NA & NA & NA \\
\hline 1 & 070901 & 9 & 32 & $100 \% \mathrm{C}$ (as $16.2 \mathrm{~g}$ glycolic acid) & 0.84 & 0 & 0.73 & 0.20 & NA & 0.94 & 0.03 \\
\hline 2 & 070501 & 11 & 18.2 & 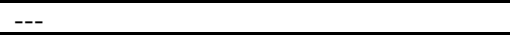 & 0.63 & 0 & 0.75 & NA & NA & 0.75 & NA \\
\hline 2 & 071001 & 11 & 18.5 & $\overline{---}$ & 1.12 & 0 & 0.92 & 0.06 & NA & 0.97 & 0.19 \\
\hline 2 & 071101 & 11 & 18.5 & 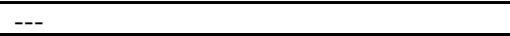 & 1.01 & 0 & 0.70 & 0.08 & NA & 0.78 & NA \\
\hline 2 & 071301 & 22 & 20 & $\overline{---}$ & 0.94 & 0 & 0.66 & 0.14 & 0.00 & 0.79 & 0.10 \\
\hline 2 & 072001 & 22 & 20 & 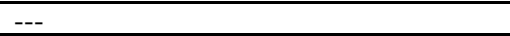 & 1.17 & 0 & 0.61 & 0.15 & 0.00 & 0.76 & NA \\
\hline 2 & 072301 & 24 & 20 & ב-- & 1.12 & 2 & 0.59 & 0.18 & 0.02 & 0.79 & $\mathrm{NA}$ \\
\hline 2 & 072401 & 23 & 20 & $-\ldots$ & 1.57 & 3 & 0.82 & 0.11 & 0.00 & 0.94 & $\mathrm{NA}$ \\
\hline 2 & 072501 & 25 & 20 & --- & 1.25 & 3 & 0.65 & 0.18 & 0.01 & 0.84 & $\mathrm{NA}$ \\
\hline 2 & 072601 & 26 & 20 & --- & 1.16 & 3 & 0.60 & 0.14 & 0.06 & 0.80 & $\mathrm{NA}$ \\
\hline 2 & 080901 & 27 & 20 & --- & 1.12 & 0 & 0.59 & 0.17 & NA & 0.75 & 0.04 \\
\hline 3 & 110601 & 22 & 20 & carbonates, high sugar & $\mathrm{NA}$ & NA & NA & NA & NA & NA & NA \\
\hline 3 & 110801 & 22 & 20 & hydroxides, high sugar & 0.70 & 0 & 0.77 & 0.12 & NA & 0.89 & 0.15 \\
\hline 3 & 111201 & 22 & 20 & frit, high sugar & 0.55 & 0 & 0.60 & 0.24 & NA & 0.84 & 0.63 \\
\hline 3 & 111301 & 22 & 20 & frit, med sugar & 0.66 & 0 & 0.72 & 0.21 & NA & 0.93 & 0.37 \\
\hline 3 & 111401 & 22 & 20 & frit, high sugar & 0.55 & 0 & 0.60 & 0.19 & NA & 0.79 & 0.49 \\
\hline 3 & 111601 & 22 & 20 & frit, med sugar & 0.61 & 0 & 0.66 & 0.19 & NA & 0.86 & 0.48 \\
\hline 3 & 121201 & 22 & 20 & hydroxides, med sugar & 0.80 & 0 & 0.88 & NA & NA & 0.88 & 0.04 \\
\hline 3 & 121301 & 22 & 20 & frit, med sugar, high $\mathrm{S}$ & 0.89 & 0 & 0.53 & NA & NA & 0.53 & 0.42 \\
\hline 3 & 121401 & 22 & 20 & frit, med sugar & 0.75 & 0 & 0.82 & NA & NA & 0.82 & 0.11 \\
\hline 3 & 122101 & 22 & 20 & hydroxides, med sugar, variable feed rate & $\mathrm{NA}$ & 0 & $\mathrm{NA}$ & NA & NA & NA & $\mathrm{NA}$ \\
\hline 3 & 010402 & 22 & 20 & hydroxides, low sugar & 0.82 & 0 & 0.90 & 0.06 & NA & 0.96 & 0.09 \\
\hline 3 & 010802 & 22 & 20 & frit, low sugar & 0.88 & 0 & 0.97 & 0.03 & NA & 1.00 & 0.05 \\
\hline 3 & 010902 & 22 & 20 & frit $(-\mathrm{Ca},-\mathrm{V})$, low sugar & 0.87 & 0 & 0.95 & 0.02 & NA & 0.97 & 0.06 \\
\hline 3 & 011002 & 22 & 20 & frit $(-\mathrm{V})$, low sugar & 0.87 & 0 & 0.96 & 0.02 & NAN & 0.97 & 0.05 \\
\hline 3 & 011102 & 22 & 20 & frit (-Ca), low sugar & 0.85 & 0 & 0.93 & 0.02 & NA & 0.95 & 0.06 \\
\hline
\end{tabular}


The set-three tests were designed to determine the influence of the chemical form of the additives the addition of $\mathrm{HNO}_{3}$, and sugar additions on the sulfur behavior of SBW-22-20 processed in the CSM. Five variations of additives were used in testing:

1. Hydroxides and oxides of all additives where used in tests CSM110801, CSM121201, CSM122101, and CSM010402.

2. The additives were prefritted into a glass that was ground and used in tests CSM111201, CSM111301, CSM111401, CSM111601, CSM121301, CSM121401, and CSM010802.

3. All of the additives except $\mathrm{CaO}$ and $\mathrm{V}_{2} \mathrm{O}_{5}$ were prefritted into a glass that was used in test CSM010902.

4. All of the additives except $\mathrm{V}_{2} \mathrm{O}_{5}$ were prefritted into a glass that was used in test CSM011002.

5. All of the additives except $\mathrm{CaO}$ were prefritted into a glass that was used in test CSM011102.

Those tests with hydroxide- and oxide-based feeds required the addition of $\mathrm{HNO}_{3}$ to give the feed adequate rheological properties to allow for pumping through the feed system of the CSM. Table 7.7 summarizes the concentrations of sugar and nitrate and the glass redox. Oddly, there is not a clear relationship between redox $\left(\mathrm{Fe}^{\mathrm{II}} / \mathrm{Fe}\right.$ or $\left.\mathrm{Fe}^{\mathrm{II}} / \mathrm{Fe}^{\mathrm{III}}\right)$ and the mole ratio of $\mathrm{NO}_{3}: \mathrm{C}$ for these samples. Figure 7.2 shows that, generally, redox is decreased by increasing $\mathrm{NO}_{3}: \mathrm{C}$; however, clearly there are other physical and chemical parameters that affect redox in addition to the $\mathrm{NO}_{3}: \mathrm{C}$ ratio. The appropriate amount of sugar to add to frit-based SBW-22 melter feeds is roughly $50 \mathrm{~g} / \mathrm{L}$ of waste simulant. However, for hydroxide-based SBW-22 melter feeds, $100 \mathrm{~g}$ of $\mathrm{HNO}_{3} / \mathrm{L}$ of simulant is used to obtain appropriate rheology, and this requires roughly $115 \mathrm{~g}$ of sugar/L of SBW to obtain a redox of roughly $5 \%$ reduced in CSM tests. It is yet unclear how this translates to other melter systems.

Table 7.7. Summary of Glass Redox and Sugar/ $\mathrm{NO}_{3}$ Concentrations

\begin{tabular}{||l|l|c|c|c|c||}
\hline Test ID & Description & $\begin{array}{c}\text { Sugar } \\
\text { g/L SBW }\end{array}$ & $\begin{array}{c}\mathbf{H N O}_{3} \\
\text { g/L SBW }\end{array}$ & $\begin{array}{c}\mathbf{N O}_{3}: \mathbf{C} \\
(\mathbf{m o l e} \text { ratio) }\end{array}$ & $\mathbf{F e}^{\mathbf{I I}} / \mathbf{F e}$ \\
\hline 110801 & hydroxides, high sugar & 207 & 100 & 0.938 & 0.15 \\
\hline 111201 & frit, high sugar & 207 & 100 & 0.938 & 0.63 \\
\hline 111301 & frit, med sugar & 160 & --- & 0.940 & 0.37 \\
\hline 111401 & frit, high sugar & 207 & 100 & 0.938 & 0.49 \\
\hline 111601 & frit, med sugar & 160 & --- & 0.940 & 0.48 \\
\hline 121201 & hydroxides, med sugar & 160 & 100 & 1.214 & 0.04 \\
\hline 121301 & frit, med sugar, high S & 160 & --- & 0.940 & 0.42 \\
\hline 121401 & frit, med sugar & 160 & 100 & 1.214 & 0.11 \\
\hline 010402 & hydroxides, low sugar & 127 & 100 & 1.530 & 0.09 \\
\hline 010802 & frit, low sugar & 51 & --- & 2.948 & 0.05 \\
\hline 010902 & frit (-Ca, -V), low sugar & 51 & --- & 2.948 & 0.06 \\
\hline 011002 & frit (-V), low sugar & 51 & --- & 2.948 & 0.05 \\
\hline 011102 & frit (-Ca), low sugar & 51 & --- & 2.948 & 0.06 \\
\hline
\end{tabular}




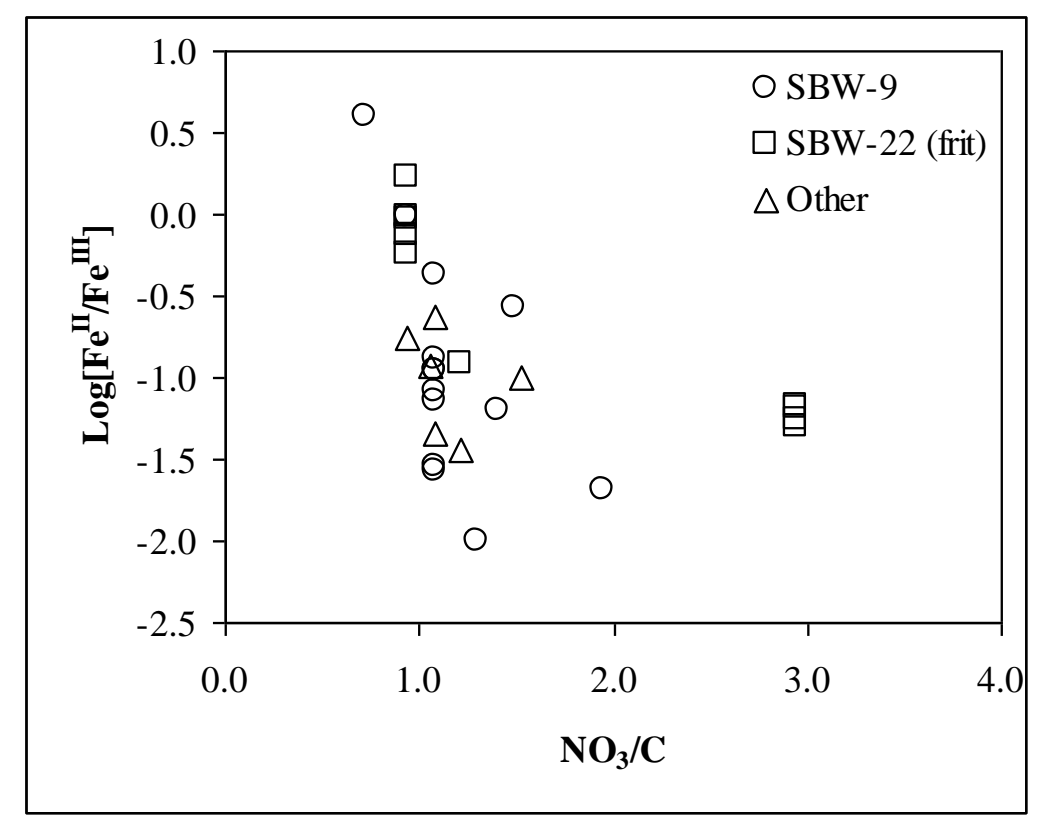

Figure 7.2. Redox as a Function of $\mathrm{NO}_{3}: \mathrm{C}$ Ratio

No significant difference between the sulfur partitioning was seen in tests with $\mathrm{CaO}, \mathrm{V}_{2} \mathrm{O}_{5}$, or both being removed from the frit or between tests with frit and the hydroxide-based feeds. It is therefore recommended that a prefabricated frit (containing all additive components) be used in testing SBW vitrification.

\subsection{Summary of SMRF Tests}

Before RSM or pilot-scale tests, it was desirable to evaluate various formulations (or melter feeds) for their potential to form salt layers using the slurry-fed melt-rate furnace (SMRF). Cozzi et al. (2002) provide a more detailed description of these tests. The SMRF has two chambers. As shown in Figure 7.3, the lower chamber is heated by three $\mathrm{SiC}$ heating elements, and the upper chamber is heated by four plate heaters. An 8-in.-diameter Inconel ${ }^{\circledR}$ crucible is positioned in the furnace so that the bottom of the crucible is flush with the top of the lower chamber, and the top of the crucible is flush with the top of the furnace. The $\mathrm{SiC}$ elements in the lower chamber heat the crucible from the bottom. This method of heating creates a vertical temperature profile in the crucible similar to the one-dimensional heat transfer from a glass pool to a cold cap. The plate heaters are used to maintain the plenum temperature at the selected setpoint.

The top of the crucible contains three ports: a thermocouple port to measure plenum temperature, a vent port to allow gases to escape, and a port to insert the feed tube. The furnace has a thermocouple inserted into the lower chamber so that the tip is positioned directly underneath the crucible bottom. The power (to the plates in the upper chamber) to maintain plenum temperature is controlled by a feedback loop from the thermocouple in the plenum. The glass-pool temperature is maintained by adjusting the power input to the $\mathrm{SiC}$ elements in the lower chamber to maintain a constant temperature in the lower chamber. The power to the SiC elements is controlled by a feedback loop from the thermocouple in contact with the Inconel ${ }^{\circledR}$ crucible. 


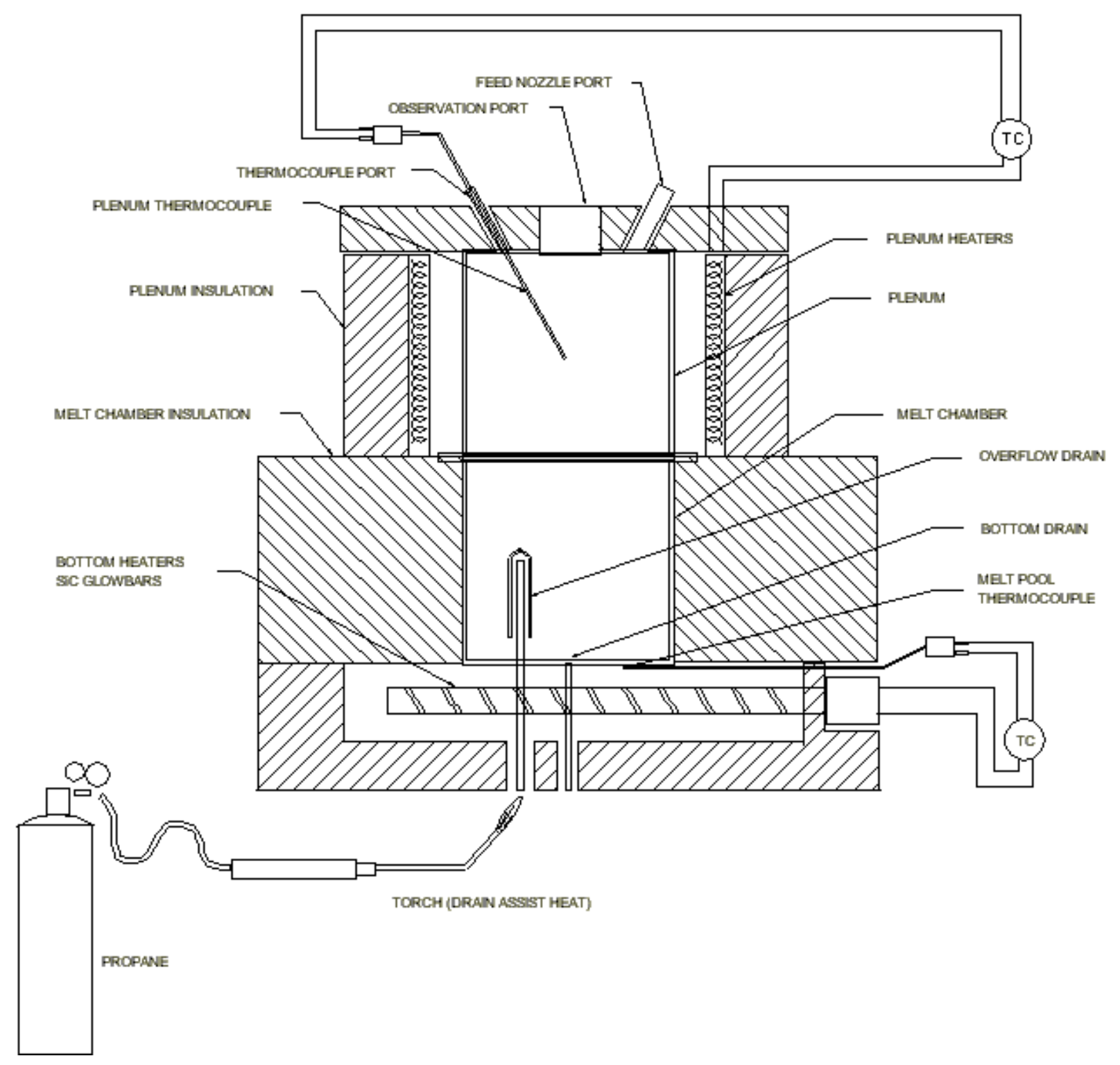

Figure 7.3. Schematic of the Melt-Rate Furnace

The feed system consists of a feed vessel with agitation set on a weigh scale, a dispensing peristaltic pump, and a water-jacketed feed tube, as shown in Figure 7.4. The pump is set up to dispense the same amount of feed each time the controller triggers the pump. The controller triggers the pump to run, based on a set-point plenum temperature. When the pump is triggered, the plenum drops 20 to $30^{\circ} \mathrm{C}$ as the feed is added. After the pump stops, the plenum temperature recovers as the feed burns off. When the plenum temperature rises back to the setpoint, the feed controller triggers the feed pump, and more feed is dispensed - setting up a semi-continuous feeding system. The controller was set to trigger feeding at $750^{\circ} \mathrm{C}$ during all four runs. 
The glass is poured from the crucible to maintain a constant level using an overflow tube heated by a propane torch. A drain tube is also installed on the crucible to empty the vessel at the conclusion of a run, if desired. A scale is used to record the amount of glass poured.

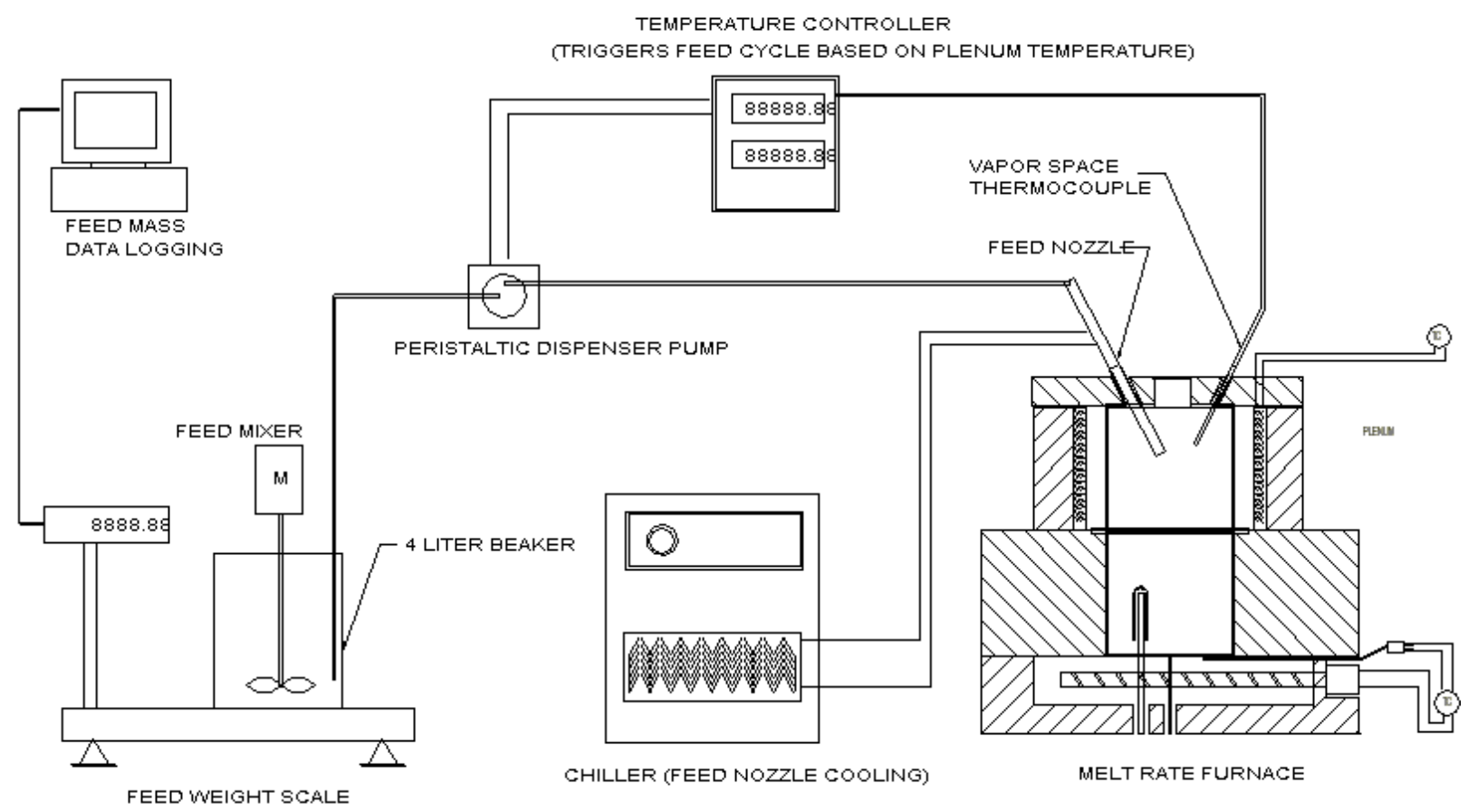

Figure 7.4. Schematic of the SMRF and feed system

Four runs were performed with the SMRF to assess the processability and sulfur behavior during the vitrification of SBW. These tests represent a significant scale-up of the vitrification process as compared to the CSM. The results of these four tests are described below.

\subsubsection{Run 1: SBW-9-30}

Run 1 was an 8-h run with operating parameters set to mimic to the extent possible the run conditions of the FY01 EV-16 run (Perry et al. 2001). Using melter feed from the EV-16 run (based on SBW-9 additives at a $30 \% \mathrm{WL}$ ), Run 1 resulted in a glass pool with a salt layer similar to that observed in the EV-16 melter. Over $17 \mathrm{~kg}$ of melter feed were processed. As previously mentioned, although laboratoryscale testing had not indicated the formation of a salt layer, the as-batched $\mathrm{SO}_{3}$ concentration in the EV-16 melter feed was the equivalent of 1.35 mass $\%$, significantly higher than the target value of 1.07 mass $\%$.

\subsubsection{Run 2: SBW-9-18.2}

The primary objective for Run 2 (SBW-9 additives at 18.2\% WL) was two-fold: 1 ) to assess the potential salt-layer formation at a lower WL and 2) to provide a compositional transition to the 2001 WM-180 simulate (glass turnover from Run 1 in anticipation of using the WM-180 2001 simulant for 
Runs 3 and 4). Run 2 was an 8-h run based on the revised 2001 SBW simulant with melter operational parameters equivalent to Run 1 . Over $18 \mathrm{~kg}$ of melter feed were processed during this run with no visible salt layer present. This indicated that by lowering the WL to $18.2 \%$, the formation of a salt layer could be eliminated or at least minimized.

\subsubsection{Run 3: SBW-22-18.2}

This was an 8-h run with the 2001 SBW simulant composition and SBW-22 composition at $18.2 \%$ loading (Stone 2001a). Run 3 was performed to assess if a salt layer would form or accumulate using the glass composition being evaluated for recommendation for future RSM and EV-16 runs. Melter feed was made using the 2001 SBW simulant, and as in Run 2, it was mixed with glass formers. Sugar was used as the reductant at the levels tested in the CSM at PNNL (135 g sugar/L SBW simulant). Additional water and nitric acid were necessary to allow the feed to be pumped. The nitrate additions were compensated by trimming the feed with $33 \mathrm{~g}$ sugar/mole nitrate added as nitric acid. During the $8 \mathrm{~h}$ of furnace operation, over $15 \mathrm{~kg}$ of melter feed were added to the furnace, producing more than $4 \mathrm{~kg}$ of glass. Coldcap, melt-pool, and glass-pour-stream samples were taken throughout the test.

No evidence of sulfur or salt accumulation was observed in the cold-cap samples or by visual observation after cold-cap burn off.

\subsubsection{Run 4: SBW-22-20a, -22b}

This run was a 48-h run with the revised 2001 SBW simulant composition and SBW-22 composition at $20 \%$ loading (Stone 2001b). Approximately $33 \mathrm{~h}$ into the run, the loading was increased to $22 \%$. The increase in waste loading was implemented as there was no appreciable salt layer forming at a waste loading of $20 \mathrm{wt} \%$. The increase was an attempt to determine if the $20 \mathrm{wt} \%$ waste loading was the maximum obtainable for this simulant composition, or if higher waste loadings were attainable. Run 4 was performed to determine if a salt layer forms during extended processing and, if it is stable, diminishes or expands. A cold-cap sample and a glass-pour sample were taken every $8 \mathrm{~h}$ of operation. During this time, feeding was suspended for $30 \mathrm{~min}$, and a dip sample was taken.

As in the previous run, running SBW-22 at 20 and 22\% WL showed no evidence of salt accumulation.

\subsubsection{Summary}

The results of the four tests are summarized in Table 7.8. The SMRF results are similar to crucible melts and CSM melts in that SBW-22-20 was easily processed without the formation of a salt and with nearly full incorporation of sulfur into the glass. This test revealed a barely detectable wisp of salt when $22 \%$ WL was processed in both SMRF and Method 1 crucible melts, which is another key similarity to previous tests. 
Table 7.8. Summary of SMRF Test Runs with SBW Simulants

\begin{tabular}{|c|c|c|c|c|c|c|c|}
\hline Run & Test ID & time (h) & Sim & $\begin{array}{c}\text { Target } \mathrm{SO}_{3} \\
(\%)\end{array}$ & $\begin{array}{c}\text { Measured } \\
\mathrm{SO}_{3}(\%) \\
\end{array}$ & Salt & Comments \\
\hline 1 & SBW-9-18.2 & 8 & 2001 & 0.83 & 0.77 & None & $\begin{array}{l}\text { Melter dip sample contained } \\
0.88 \text { mass } \% \mathrm{SO}_{3} \text {. }\end{array}$ \\
\hline 2 & SBW-9-30 & 8 & $\begin{array}{c}2000 \text { from } \\
\text { Perry et al. } \\
(2001)\end{array}$ & 1.35 & 0.95 & Salt Layer & $\begin{array}{l}\text { Although the target level of } \\
\mathrm{SO}_{3} \text { was } 1.07 \% \text {, feed from } \\
\text { a previous pilot melter test } \\
\text { was used with significantly } \\
\text { higher } \mathrm{SO}_{3} \text { than targeted. } \\
\text { The melter-dip sample } \\
\text { contained } 1.17 \text { mass } \% \mathrm{SO}_{3} \text {. }\end{array}$ \\
\hline 3 & SBW-22-18.2 & 8 & 2001 & 0.84 & 0.80 & None & \\
\hline $4 \mathrm{a}$ & SBW-22-20 & 33 & 2001 & 0.91 & 0.94 & None & \\
\hline $4 \mathrm{~b}$ & SBW-22-22 & 15 & 2001 & 1.00 & 0.99 & None & \\
\hline
\end{tabular}




\subsection{Conclusions and Recommendations}

The results from the tests presented above suggest that SBW-22 frit (or additive mix) is appropriate for scale-up tests of the direct vitrification of $2001 \mathrm{WM}-180$ simulant at 20 mass $\%$ loading. This composition is summarized in Table 8.1 on a mass $\%$ oxide basis. The glass was formulated to be processable in both a JHCM and an ICCM with properties sufficient for disposal of the glass at the planned federal geologic repository.

Table 8.1. SBW-22-20 Composition

\begin{tabular}{|c|c|c|c|}
\hline 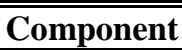 & 2001 WM-180 & " SBW-22 (additives) & "SBW-22-20 \\
\hline $\mathrm{Ag}_{2} \mathrm{O}$ & 0.001 & & 0.000 \\
\hline $\mathrm{Al}_{2} \mathrm{O}_{3}$ & 27.524 & & 5.505 \\
\hline $\mathrm{As}_{2} \mathrm{O}_{3}$ & 0.040 & & 0.008 \\
\hline $\mathrm{B}_{2} \mathrm{O}_{3}$ & 0.349 & 6.035 & 4.898 \\
\hline $\mathrm{BaO}$ & 0.007 & & 0.001 \\
\hline $\mathrm{CaO}$ & 2.154 & 5.020 & 4.447 \\
\hline $\mathrm{CdO}$ & 0.079 & & 0.016 \\
\hline $\mathrm{Ce}_{2} \mathrm{O}_{3}$ & 0.013 & & 0.003 \\
\hline $\mathrm{Cl}$ & 0.865 & & 0.173 \\
\hline $\mathrm{CoO}$ & 0.001 & & 0.000 \\
\hline $\mathrm{Cr}_{2} \mathrm{O}_{3}$ & 0.207 & & 0.041 \\
\hline $\mathrm{Cs}_{2} \mathrm{O}$ & 0.001 & & 0.000 \\
\hline $\mathrm{CuO}$ & 0.045 & & 0.009 \\
\hline $\bar{F}$ & 0.733 & & 0.147 \\
\hline $\mathrm{Fe}_{2} \mathrm{O}_{3}$ & 1.412 & 1.520 & 1.498 \\
\hline $\mathrm{Gd}_{2} \mathrm{O}_{3}$ & 0.026 & & 0.005 \\
\hline I & 0.007 & & 0.001 \\
\hline $\mathrm{K}_{2} \mathrm{O}$ & 7.525 & & 1.505 \\
\hline $\mathrm{Li}_{2} \mathrm{O}$ & 0.004 & 6.110 & 4.889 \\
\hline $\mathrm{MgO}$ & 0.395 & 1.750 & 1.479 \\
\hline $\mathrm{MnO}$ & 0.814 & & 0.163 \\
\hline $\mathrm{MoO}_{3}$ & 0.023 & & 0.005 \\
\hline $\mathrm{Na}_{2} \mathrm{O}$ & 51.911 & 4.295 & 13.818 \\
\hline $\mathrm{Nb}_{2} \mathrm{O}_{5}$ & 0.002 & & 0.000 \\
\hline $\mathrm{NiO}$ & 0.089 & & 0.018 \\
\hline $\mathrm{P}_{2} \mathrm{O}_{5}$ & 0.791 & & 0.158 \\
\hline $\mathrm{PbO}$ & 0.237 & & 0.047 \\
\hline $\mathrm{PdO}$ & 0.002 & & 0.000 \\
\hline $\mathrm{ReO}_{2}$ & 0.001 & & 0.000 \\
\hline $\mathrm{RuO}_{2}$ & 0.014 & & 0.003 \\
\hline $\mathrm{Sb}_{2} \mathrm{O}_{3}$ & 0.008 & & 0.002 \\
\hline $\mathrm{SeO}_{2}$ & 0.013 & & 0.003 \\
\hline $\mathrm{SiO}_{2}$ & & 67.951 & 54.360 \\
\hline $\mathrm{SO}_{3}$ & 4.548 & & 0.910 \\
\hline $\mathrm{SrO}$ & 0.010 & & 0.002 \\
\hline $\mathrm{TiO}_{2}$ & 0.004 & & 0.001 \\
\hline $\mathrm{V}_{2} \mathrm{O}_{5}$ & 0.068 & 4.880 & 3.918 \\
\hline $\mathrm{ZnO}$ & 0.069 & & 0.014 \\
\hline$\overline{\mathrm{ZrO}_{2}}$ & 0.007 & 2.440 & 1.953 \\
\hline SUM & 100.000 & 100.000 & 100.000 \\
\hline
\end{tabular}


The main focus of formulation work and testing was minimizing the likelihood of salt accumulation and maximizing sulfur retention in the melt. Since these are both strong functions of the chemical and physical processes involved in the melter, it is difficult to extrapolate the results from smaller scale tests performed during this study to the melter. Therefore, it is recommended that the glass be fabricated in scaled melter tests to assure that processability is adequate at a larger scale. 


\subsection{References}

American Society for Testing and Materials (ASTM). 1990. "Standard Practice for Measuring Viscosity of Glass Above the Softening Point." ASTM C 965-81. In: Annual Book of ASTM Standards, Vol. 15.02, Philadelphia, PA.

American Society for Testing and Materials (ASTM). 1998. "Standard Test Method for Determining Chemical Durability of Nuclear Waste Glasses, The Product Consistency Test (PCT)." ASTM-C-128597, in Annual Book of ASTM Standards, Vol 12.01, Philadelphia, PA.

Christian J. 2001. Composition and Simulation of Tank WM-180 Sodium-Bearing Waste at the Idaho Nuclear Technology and Engineering Center, INEEL/EXT-01-00600, Idaho National Engineering and Environmental Laboratory, Idaho Falls, ID.

Cozzi AD, DF Bickford, and ME Stone. 2002. Slurry Fed Melt Rate Furnace Runs to Support Glass Formulation Development for INEEL Sodium-Bearing Waste, WSRC-TR-2002-00192, Westinghouse Savannah River Company, Aiken, SC.

Darab JG, DD Graham, BD MacIsaac, RL Russell, DK Peeler, HD Smith, and JD Vienna. 2001. Sulfur Partitioning During Vitrification of INEEL Sodium Bearing Waste: Status Report, PNNL-13588, Pacific Northwest National Laboratory, Richland, WA.

DOE, see U.S. Department of Energy

Edwards TB, DK Peeler, JD Vienna, GF Piepel, and SK Cooley. 2001. Development of Sodium Bearing Waste Composition Variation Study Test Matrix (U), WSRC-TR-2001-00700, Rev. 0, Westinghouse Savannah River Company, Aiken, SC.

Goles RW, JM Perez, BD MacIsaac, DD Siemer, and JA McCray. 2001. Test summary Report INEEL Sodium-Bearing Waste Vitrification Demonstration RSM-01-01, PNNL-13522, Pacific Northwest Laboratory, Richland, WA.

Hrma P, GF Piepel, MJ Schweiger, DE Smith, D-S Kim, PE Redgate, JD Vienna, CA LoPresti, DB Simpson, DK Peeler, and MH Langowski. 1994. Property/Composition Relationships for Hanford HighLevel Waste Glasses Melting at $1150^{\circ}$ C, PNL-10359, Vol. 1 and 2, Pacific Northwest Laboratory, Richland, WA.

Hrma P, GF Piepel, JD Vienna, SK Cooley, D-S Kim, and RL Russell. 2001. Database and Interim Models for Hanford HLW Glasses, PNL-13573, Pacific Northwest Laboratory, Richland, WA.

Jantzen CM, NE Bibler, DC Beam, CL Crawford, and MA Pickett. 1993. Characterization of the Defense Waste Processing Facility (DWPF) Environmental Assessment (EA) Glass Standard Reference Material (U), WSRC-TR-92-346, Revision 1, Westinghouse Savannah River Company, Aiken, SC. 
Krämer FW. 1991. "Contribution to Basicity of Technical Glass Melts in Relation to Redox Equilibria and Gas Solubilities," Glastech. Ber. 64, No. 3, 71-80.

Li H, JD Vienna, PR Hrma, DE Smith, and MJ Schweiger. 1997. "Nepheline Precipitation in HighLevel Waste Glasses: Compositional Effects and Impact on the Waste Form Acceptability." In:

Scientific Basis for Nuclear Waste Management XX, Vol. 465, pp. 261-268. Materials Research Society, Pittsburgh, PA.

Li H, B Jones, P Hrma, and JD Vienna. 1998. "Compositional Effects on Liquidus Temperature of Hanford Simulated High-Level Waste Glasses Precipitating Nepheline (NaAlSiO4)," Ceram. Trans. 87, pp 279-288, American Ceramic Society, Westerville, OH.

Li H, P Hrma, and JD Vienna. 2001. "Sulfate Retention and Segregation in Simulated Radioactive Waste Borosilicate Glass," Ceram. Trans. 119, 237-246, American Ceramic Society, Westerville, OH.

Lifanov, F. A., and S. V. Stefanovskii. 1990. "Silicate Glasses and Vitroceramics for Immobilization of Radioactive Ash Arising from Incineration of Organic Wastes," Radiokhimiya, 32 [3] pp. 166-171.

Marra SL, and CM Jantzen. 1993. Characterization of Projected DWPF Glasses Heat Treated to Simulate Canister Centerline Cooling (U), WSRC-TR-92-142, Rev. 1, Westinghouse Savannah River Company, Aiken, SC.

Olson, L. G. 2001. Radioactive Crucible Scale Glass Melts Using INTEC Tank WM-180 SodiumBearing Waste, INEEL/EXT-01-01020, Idaho National Engineering and Environmental Laboratory, Idaho Falls, ID.

Peeler DK, TB Edwards, IA Reamer, RJ Workman, JD Vienna, JV Crum, and MJ Schwieger. 2001. Glass Formulation Development for INEEL Sodium-Bearing Waste (FY2001 WM-180), WSRC-TR2001-00295, Rev. 0, Westinghouse Savannah River Company, Aiken, SC.

Perry, KJ, RR Kimmitt, NR Soelberg, RD Tillotson, and AN Olson. 2001. Test Results from sBWFY91-PS-01 Vitrification Demonstration of Sodium Bearing Waste Simulant using WM-180 Surrogate, INEEL/EXT-01-01073, Idaho National Engineering and Environmental Laboratory, Idaho Fall, ID.

Savannah River Technology Center (SRTC). 1999. "Determination of Glass Viscosity." In: Glass Technology Manual L13.1, Technical Reference, GTOP-3-111, Rev. 0, Aiken, SC.

BA Schole, JD Vienna, DK Peeler, and TB Edwards. 2002. The Preparation and Characterization of INTEC Sodium Bearing Waste Phase 1 Composition Variation Study Glasses, INEEL/EXT-02-00386, Idaho National Engineering and Environmental Laboratory, Idaho Fall, ID.

Schreiber, H. D., S. J. Kozak, C. W. Schreiber, D. G. Wetmore, and M. W. Riethmiller. 1990. „Sulfur Chemistry in a Borosilicate Melt, Part 3. Iron-Sulfur Interactions and the Amber Chromophore," in Glastech. Ber. 63 [3] pp. 49-60. 
Schumacher RF, and DK Peeler. 1998. Establishment of Harrop, High Temperature Viscometer (U), WSRC-RP-98-00737, Rev. 0, Westinghouse Savannah River Company, Aiken, SC.

Stone ME. 2001a. Run Plan for Frit SBW-22 and Revised Simulant (U)," SRT-GPD-2001-00067, Savannah River Technology Center, Aiken, SC.

Stone ME. 2001b. Run Plan for 48 Hour Tests with Frit SBW-22 and Revised Simulant (U), SRT-GPD2001-00075, Savannah River Technology Center, Aiken, SC.

U.S. Department of Energy (DOE). 1995. The INEEL Spent Nuclear Fuel and Environmental Restoration and Waste Management Programs Environmental Impact Statement. DOE/EIS-0203-F, Washington D. C.

U.S. Department of Energy (DOE). 1996. Office of Environmental Management, Waste Acceptance Product Specifications for Vitrified High-Level Waste Forms, Rev. 2, DOE Document EM-WAPS, Germantown, MD.

Vienna JD, MJ Schweiger, DE Smith, HD Smith, JV Crum, DK Peeler, IA Reamer, CA Musick, and RD Tillotson. 1999. Glass Formulation Development for INEEL Sodium-Bearing Waste, PNNL-12234, Pacific Northwest National Laboratory, Richland, WA.

Vienna JD et al. 2002. "Sulfur Behavior During Waste Vitrification,” in preparation. 


\section{Appendix A}

\section{Target vs. Measured Chemical Composition Analysis}




\section{Appendix A: Target vs. Measured Chemical Composition Analysis}

\begin{tabular}{|c|c|c|c|c|c|c|}
\hline \multirow[b]{2}{*}{$\begin{array}{c}\text { WL (mass \%) } \\
\text { Oxide }\end{array}$} & \multicolumn{2}{|c|}{ SBW-11 } & \multicolumn{2}{|c|}{ SBW-12 } & \multicolumn{2}{|c|}{ SBW-13 } \\
\hline & $\begin{array}{c}18.5 \\
\text { Target }\end{array}$ & Meas. & \begin{tabular}{c|}
18.5 \\
Target
\end{tabular} & Meas. & $\begin{array}{c}18.5 \\
\text { Target }\end{array}$ & Meas. \\
\hline $\mathrm{Al}_{2} \mathrm{O}_{3}$ & 5.091 & 5.33 & 5.091 & 5.16 & 5.091 & 5.05 \\
\hline $\mathrm{B}_{2} \mathrm{O}_{3}$ & 9.967 & 10.6 & 4.979 & 4.86 & 9.967 & 9.21 \\
\hline $\mathrm{BaO}$ & 0.002 & & 0.002 & & 0.002 & \\
\hline $\mathrm{CaO}$ & 4.489 & 4.65 & 4.489 & 4.56 & 0.398 & 0.391 \\
\hline $\mathrm{CdO}$ & 0.015 & & 0.015 & & 0.015 & \\
\hline $\mathrm{Cr}_{2} \mathrm{O}_{3}$ & 0.039 & & 0.039 & 0.043 & 0.039 & 0.041 \\
\hline $\mathrm{CuO}$ & 0.009 & & 0.009 & & 0.009 & \\
\hline $\mathrm{Fe}_{2} \mathrm{O}_{3}$ & 1.500 & 1.63 & 1.500 & 1.50 & 1.500 & 1.44 \\
\hline $\mathrm{Gd}_{2} \mathrm{O}_{3}$ & 0.006 & & 0.006 & & 0.006 & \\
\hline $\mathrm{K}_{2} \mathrm{O}$ & 1.393 & 1.21 & 1.393 & 1.48 & 8.035 & 8.22 \\
\hline $\mathrm{Li}_{2} \mathrm{O}$ & 4.980 & 5.27 & 4.980 & 4.88 & 4.980 & 4.75 \\
\hline $\mathrm{MgO}$ & 1.498 & 1.59 & 1.498 & 1.50 & 0.072 & 0.045 \\
\hline $\mathrm{MnO}$ & 0.150 & 0.14 & 0.150 & 0.153 & 0.150 & 0.152 \\
\hline $\mathrm{MoO}_{3}$ & 0.004 & & 0.004 & & 0.004 & \\
\hline $\mathrm{Na}_{2} \mathrm{O}$ & 11.152 & 11.0 & 15.292 & \begin{tabular}{|l|}
15.4 \\
\end{tabular} & 11.152 & 11.1 \\
\hline $\mathrm{NiO}$ & 0.017 & & 0.017 & 0.025 & 0.017 & 0.024 \\
\hline $\mathrm{P}_{2} \mathrm{O}_{5}$ & 0.146 & & 0.146 & & 0.146 & \\
\hline $\mathrm{PbO}$ & 0.044 & & 0.044 & 0.048 & 0.044 & 0.044 \\
\hline $\mathrm{RuO}_{2}$ & 0.002 & & 0.002 & & 0.002 & \\
\hline $\mathrm{SO}_{3}$ & 0.842 & 0.749 & 0.842 & 0.824 & 0.842 & 0.819 \\
\hline $\mathrm{SiO}_{2}$ & 52.347 & 54.1 & 53.195 & \begin{tabular}{|l|}
54.1 \\
\end{tabular} & 51.223 & 52.4 \\
\hline $\mathrm{V}_{2} \mathrm{O}_{5}$ & 3.990 & 3.96 & 3.990 & (a) & 3.990 & (a) \\
\hline $\mathrm{ZnO}$ & 0.002 & & 0.002 & & 0.002 & \\
\hline $\mathrm{ZrO}_{2}$ & 1.990 & 1.89 & 1.990 & 1.97 & 1.990 & 1.96 \\
\hline $\mathrm{Cl}$ & 0.161 & & 0.161 & & 0.161 & \\
\hline $\mathrm{F}$ & 0.135 & & 0.135 & & 0.135 & \\
\hline Total & 100.00 & 102 & 100.00 & 96.0 & 100.00 & 95.2 \\
\hline
\end{tabular}




\begin{tabular}{|c|c|c|c|c|c|c|c|c|}
\hline \multirow[b]{2}{*}{$\begin{array}{c}\text { WL (mass \%) } \\
\text { Oxide }\end{array}$} & \multicolumn{2}{|c|}{ SBW-14 } & \multicolumn{2}{|c|}{ SBW-15 } & \multicolumn{2}{|c|}{ SBW-16 } & \multicolumn{2}{|c|}{ SBW-17 } \\
\hline & $\begin{array}{c}18.5 \\
\text { Target }\end{array}$ & Meas. & $\begin{array}{c}18.5 \\
\text { Target }\end{array}$ & Meas. & \begin{tabular}{|c|}
18.5 \\
Target
\end{tabular} & Meas. & \begin{tabular}{|c|}
18.5 \\
Target
\end{tabular} & Meas. \\
\hline $\mathrm{Al}_{2} \mathrm{O}_{3}$ & 5.091 & 5.12 & 5.091 & 5.08 & 5.091 & 5.12 & 5.091 & 5.23 \\
\hline $\mathrm{B}_{2} \mathrm{O}_{3}$ & 11.842 & 11.3 & 5.770 & 5.54 & 11.475 & 10.8 & 9.845 & 10.0 \\
\hline $\mathrm{BaO}$ & 0.002 & & 0.002 & & 0.002 & & 0.002 & \\
\hline $\mathrm{CaO}$ & 4.489 & 4.56 & 6.918 & 7.01 & 6.103 & 6.19 & 2.028 & 1.80 \\
\hline $\mathrm{CdO}$ & 0.015 & & 0.015 & & 0.015 & & 0.015 & \\
\hline $\mathrm{Cr}_{2} \mathrm{O}_{3}$ & 0.039 & 0.041 & 0.039 & 0.041 & 0.039 & 0.055 & 0.039 & 0.028 \\
\hline $\mathrm{CuO}$ & 0.009 & & 0.009 & & 0.009 & & 0.009 & \\
\hline $\mathrm{Fe}_{2} \mathrm{O}_{3}$ & 1.500 & 1.50 & 6.781 & 6.83 & 0.261 & 0.306 & 10.041 & 9.59 \\
\hline $\mathrm{Gd}_{2} \mathrm{O}_{3}$ & 0.006 & & 0.006 & & 0.006 & & 0.006 & \\
\hline $\mathrm{K}_{2} \mathrm{O}$ & 1.393 & 1.49 & 1.393 & 1.45 & 1.393 & 1.45 & 1.393 & 1.24 \\
\hline $\mathrm{Li}_{2} \mathrm{O}$ & 4.980 & 4.86 & 4.890 & 4.77 & 4.890 & 4.73 & 3.260 & 3.21 \\
\hline $\mathrm{MgO}$ & 1.498 & 1.50 & 0.072 & 0.045 & 0.072 & 0.053 & 0.072 & \\
\hline $\mathrm{MnO}$ & 0.150 & 0.154 & 0.150 & & 0.150 & 0.151 & 0.150 & 0.137 \\
\hline $\mathrm{MoO}_{3}$ & 0.004 & & 0.004 & & 0.004 & & 0.004 & \\
\hline $\mathrm{Na}_{2} \mathrm{O}$ & 11.152 & 11.2 & 15.308 & 14.9 & 11.233 & 11.3 & 9.603 & 9.87 \\
\hline $\mathrm{NiO}$ & 0.017 & 0.024 & 0.017 & 0.023 & 0.017 & 0.025 & 0.017 & \\
\hline $\mathrm{P}_{2} \mathrm{O}_{5}$ & 0.146 & & 0.146 & & 0.146 & & 0.146 & \\
\hline $\mathrm{PbO}$ & 0.044 & 0.044 & 0.044 & 0.046 & 0.044 & 0.043 & 0.044 & 0.040 \\
\hline $\mathrm{RuO}_{2}$ & 0.002 & & 0.002 & & 0.002 & & 0.002 & \\
\hline $\mathrm{SO}_{3}$ & 0.842 & 0.722 & 0.842 & 0.844 & 0.842 & 0.737 & 0.842 & 0.477 \\
\hline $\mathrm{SiO}_{2}$ & 54.450 & 54.3 & 52.160 & 52.4 & 57.865 & 57.1 & 57.050 & 53.6 \\
\hline $\mathrm{V}_{2} \mathrm{O}_{5}$ & 0.013 & & 0.013 & & 0.013 & & 0.013 & 0.09 \\
\hline $\mathrm{ZnO}$ & 0.002 & & 0.002 & & 0.002 & & 0.002 & \\
\hline $\mathrm{ZrO}_{2}$ & 1.990 & 1.94 & 0.002 & $<0.015$ & 0.002 & $<0.012$ & 0.002 & \\
\hline $\mathrm{Cl}$ & 0.161 & & 0.161 & & 0.161 & & 0.161 & \\
\hline $\mathrm{F}$ & 0.135 & & 0.135 & & 0.135 & & 0.135 & \\
\hline Total & 100.00 & 98.3 & 100.00 & 98.5 & 100.00 & 97.6 & 100.00 & 95.0 \\
\hline
\end{tabular}




\begin{tabular}{|c|c|c|c|c|c|c|c|c|}
\hline \multirow[b]{2}{*}{$\begin{array}{c}\text { WL }(\operatorname{mass} \%) \\
\text { Oxide }\end{array}$} & \multicolumn{2}{|c|}{ SBW-18 } & \multicolumn{2}{|c|}{ SBW-19 } & \multicolumn{2}{|c|}{ SBW-20 } & \multicolumn{2}{|c|}{ SBW-21 } \\
\hline & \begin{tabular}{c|}
18.5 \\
Target
\end{tabular} & Meas. & \begin{tabular}{|c|}
18.5 \\
Target
\end{tabular} & Meas. & \begin{tabular}{|c|}
18.5 \\
Target
\end{tabular} & Meas. & $\begin{array}{c}18.5 \\
\text { Target }\end{array}$ & Meas. \\
\hline $\mathrm{Al}_{2} \mathrm{O}_{3}$ & 5.091 & 5.24 & 5.091 & 5.33 & 5.091 & 5.30 & 5.091 & 5.42 \\
\hline $\mathrm{B}_{2} \mathrm{O}_{3}$ & 9.845 & 9.89 & 9.845 & 9.86 & 9.845 & 9.85 & 8.215 & 8.29 \\
\hline $\mathrm{BaO}$ & 0.002 & & 0.002 & & 0.002 & & 0.002 & \\
\hline $\mathrm{CaO}$ & 2.028 & 1.77 & 2.028 & 1.80 & 3.658 & 3.71 & 3.658 & 3.82 \\
\hline $\mathrm{CdO}$ & 0.015 & & 0.015 & & 0.015 & & 0.015 & \\
\hline $\mathrm{Cr}_{2} \mathrm{O}_{3}$ & 0.039 & 0.031 & 0.039 & 0.032 & 0.039 & 0.040 & 0.039 & 0.047 \\
\hline $\mathrm{CuO}$ & 0.009 & & 0.009 & & 0.009 & & 0.009 & \\
\hline $\mathrm{Fe}_{2} \mathrm{O}_{3}$ & 10.041 & 9.69 & 10.041 & 9.89 & 10.041 & 10.0 & 10.041 & 10.1 \\
\hline $\mathrm{Gd}_{2} \mathrm{O}_{3}$ & 0.006 & & 0.006 & & 0.006 & & 0.006 & \\
\hline $\mathrm{K}_{2} \mathrm{O}$ & 1.393 & 1.27 & 1.393 & 1.28 & 1.393 & 1.27 & 1.393 & 1.27 \\
\hline $\mathrm{Li}_{2} \mathrm{O}$ & 2.445 & 2.18 & 2.445 & 2.14 & 2.445 & 2.13 & 2.445 & 2.10 \\
\hline $\mathrm{MgO}$ & 0.072 & & 0.072 & & 0.072 & & 0.072 & \\
\hline $\mathrm{MnO}$ & 0.150 & 0.135 & 0.150 & 0.143 & 0.150 & 0.137 & 0.150 & 0.141 \\
\hline $\mathrm{MoO}_{3}$ & 0.004 & & 0.004 & & 0.004 & & 0.004 & \\
\hline $\mathrm{Na}_{2} \mathrm{O}$ & 12.863 & 12.4 & 12.863 & 12.6 & 12.863 & 12.6 & 12.863 & 12.6 \\
\hline $\mathrm{NiO}$ & 0.017 & & 0.017 & & 0.017 & & 0.017 & \\
\hline $\mathrm{P}_{2} \mathrm{O}_{5}$ & 0.146 & & 0.146 & & 0.146 & & 0.146 & \\
\hline $\mathrm{PbO}$ & 0.044 & 0.041 & 0.044 & 0.041 & 0.044 & 0.040 & 0.044 & 0.042 \\
\hline $\mathrm{RuO}_{2}$ & 0.002 & & 0.002 & & 0.002 & & 0.002 & \\
\hline $\mathrm{SO}_{3}$ & 0.842 & 0.602 & 0.842 & 0.527 & 0.842 & 0.589 & 0.842 & 0.582 \\
\hline $\mathrm{SiO}_{2}$ & 52.160 & 51.4 & 50.530 & 50.9 & 48.900 & 49.9 & 50.530 & 51.7 \\
\hline $\mathrm{V}_{2} \mathrm{O}_{5}$ & 1.643 & 1.64 & 3.273 & 3.24 & 3.273 & 3.31 & 3.273 & 3.29 \\
\hline $\mathrm{ZnO}$ & 0.002 & & 0.002 & & 0.002 & & 0.002 & \\
\hline $\mathrm{ZrO}_{2}$ & 0.817 & & 0.817 & & 0.817 & 0.777 & 0.817 & 0.757 \\
\hline $\mathrm{Cl}$ & 0.161 & & 0.161 & & 0.161 & & 0.161 & \\
\hline $\mathrm{F}$ & 0.135 & & 0.135 & & 0.135 & & 0.135 & \\
\hline Total & 100.00 & 97.0 & 100.00 & 98.0 & 100.00 & 99.0 & 100.00 & 100 \\
\hline
\end{tabular}




\begin{tabular}{|c|c|c|c|c|c|c|c|c|}
\hline \multirow{3}{*}{$\begin{array}{c}\text { WL (mass \%) } \\
\text { Oxide }\end{array}$} & \multicolumn{8}{|c|}{ SBW-22 } \\
\hline & 15 & & 18.5 & & 20 & & 25 & \\
\hline & Target & Meas. & Target & Meas. & Target & Meas. & Target & Meas. \\
\hline $\mathrm{Al}_{2} \mathrm{O}_{3}$ & 4.12 & 4.27 & 5.09 & 5.18 & 5.50 & 5.63 & 6.88 & 7.03 \\
\hline $\mathrm{B}_{2} \mathrm{O}_{3}$ & 5.17 & 5.28 & 4.97 & 4.89 & 4.89 & 4.67 & 4.611 & 4.35 \\
\hline $\mathrm{BaO}$ & 0.00 & & 0.00 & & 0.00 & & 0.00 & \\
\hline $\mathrm{CaO}$ & 4.59 & 4.23 & 4.48 & 4.06 & 4.44 & 4.07 & 4.30 & 4.00 \\
\hline $\mathrm{CdO}$ & 0.01 & & 0.01 & & 0.01 & & 0.02 & \\
\hline $\mathrm{Cr}_{2} \mathrm{O}_{3}$ & 0.03 & 0.032 & 0.03 & 0.074 & 0.04 & 0.058 & 0.05 & 0.058 \\
\hline $\mathrm{CuO}$ & 0.00 & & 0.00 & & 0.01 & & 0.01 & \\
\hline $\mathrm{Fe}_{2} \mathrm{O}_{3}$ & 1.50 & 1.76 & 1.50 & 1.50 & 1.49 & 1.47 & 1.49 & 1.49 \\
\hline $\mathrm{Gd}_{2} \mathrm{O}_{3}$ & 0.00 & & 0.00 & & 0.00 & & 0.00 & \\
\hline $\mathrm{K}_{2} \mathrm{O}$ & 1.13 & 1.25 & 1.39 & 1.49 & 1.50 & 1.66 & 1.88 & 2.10 \\
\hline $\mathrm{Li}_{2} \mathrm{O}$ & 5.19 & 4.97 & 4.98 & 4.79 & 4.88 & 4.62 & 4.58 & 4.30 \\
\hline $\mathrm{MgO}$ & 1.54 & 1.61 & 1.49 & 1.52 & 1.47 & 1.51 & 1.41 & 1.46 \\
\hline $\mathrm{MnO}$ & 0.12 & 0.12 & 0.15 & 0.14 & 0.16 & 0.15 & 0.20 & 0.20 \\
\hline $\mathrm{MoO}_{3}$ & 0.00 & & 0.00 & & 0.00 & & 0.00 & \\
\hline $\mathrm{Na}_{2} \mathrm{O}$ & 11.433 & 11.29 & 13.100 & 12.81 & 13.814 & 13.50 & 16.195 & 16.20 \\
\hline $\mathrm{NiO}$ & 0.01 & 0.018 & 0.01 & 0.019 & 0.01 & 0.02 & 0.02 & 0.024 \\
\hline $\mathrm{P}_{2} \mathrm{O}_{5}$ & 0.11 & 0.13 & 0.14 & 0.15 & 0.15 & 0.17 & 0.19 & 0.21 \\
\hline $\mathrm{PbO}$ & 0.03 & 0.04 & 0.04 & 0.04 & 0.04 & 0.05 & 0.06 & 0.06 \\
\hline $\mathrm{RuO}_{2}$ & 0.00 & & 0.00 & & 0.00 & & 0.00 & \\
\hline $\mathrm{SO}_{3}$ & 0.68 & 0.599 & 0.84 & 0.737 & 0.91 & 0.806 & 1.13 & 1.074 \\
\hline $\mathrm{SiO}_{2}$ & 57.760 & 58.42 & 55.387 & 53.93 & 54.368 & 55.00 & 50.970 & 52.22 \\
\hline $\mathrm{V}_{2} \mathrm{O}_{5}$ & 4.15 & 4.01 & 3.99 & 3.74 & 3.91 & 3.69 & 3.67 & 3.49 \\
\hline $\mathrm{ZnO}$ & 0.00 & & 0.00 & & 0.00 & & 0.00 & \\
\hline $\mathrm{ZrO}_{2}$ & 2.07 & 1.958 & 1.99 & 1.823 & 1.95 & 1.823 & 1.83 & 1.755 \\
\hline $\mathrm{Cl}$ & 0.13 & & 0.16 & & 0.17 & & 0.21 & \\
\hline $\bar{F}$ & 0.11 & & 0.13 & & 0.14 & & 0.18 & \\
\hline Total & 100.00 & 100.09 & 100.00 & 97.01 & 100.00 & 99.01 & 100.00 & 100.12 \\
\hline
\end{tabular}




\begin{tabular}{|c|c|c|c|c|c|c|c|c|}
\hline \multirow[b]{2}{*}{$\begin{array}{c}\text { WL (mass \%) } \\
\text { Oxide }\end{array}$} & \multicolumn{8}{|c|}{ SBW-23 } \\
\hline & \begin{tabular}{|c|}
15 \\
Target
\end{tabular} & Meas. & $\begin{array}{c}18.5 \\
\text { Target }\end{array}$ & Meas. & \begin{tabular}{|c|}
20 \\
Target
\end{tabular} & Meas. & \begin{tabular}{|c|}
25 \\
Target
\end{tabular} & Meas. \\
\hline $\mathrm{Al}_{2} \mathrm{O}_{3}$ & 4.128 & 4.12 & 5.091 & 5.16 & 5.504 & 5.54 & 6.880 & 6.75 \\
\hline $\mathrm{B}_{2} \mathrm{O}_{3}$ & 10.380 & 10.2 & 9.967 & 9.72 & 9.790 & 9.55 & 9.200 & 8.84 \\
\hline $\mathrm{BaO}$ & 0.002 & & 0.002 & & 0.002 & & 0.003 & \\
\hline $\mathrm{CaO}$ & 0.323 & $<0.004$ & 0.398 & 0.174 & 0.430 & 0.151 & 0.538 & 0.248 \\
\hline $\mathrm{CdO}$ & 0.012 & & 0.015 & & 0.016 & & 0.020 & \\
\hline $\mathrm{Cr}_{2} \mathrm{O}_{3}$ & 0.032 & & 0.039 & & 0.042 & & 0.053 & \\
\hline $\mathrm{CuO}$ & 0.008 & & 0.009 & & 0.010 & & 0.013 & \\
\hline $\mathrm{Fe}_{2} \mathrm{O}_{3}$ & 1.504 & 1.67 & 1.500 & 1.63 & 1.498 & 1.67 & 1.493 & 1.66 \\
\hline $\mathrm{Gd}_{2} \mathrm{O}_{3}$ & 0.005 & & 0.006 & & 0.006 & & 0.008 & \\
\hline $\mathrm{K}_{2} \mathrm{O}$ & 4.802 & 4.27 & 4.914 & 4.38 & 4.962 & 4.50 & 5.123 & 4.46 \\
\hline $\mathrm{Li}_{2} \mathrm{O}$ & 5.194 & 5.44 & 4.980 & 5.28 & 4.888 & 5.22 & 4.583 & 4.85 \\
\hline $\mathrm{MgO}$ & 0.059 & 0.04 & 0.072 & 0.06 & 0.078 & 0.060 & 0.098 & 0.090 \\
\hline $\mathrm{MnO}$ & 0.122 & 0.12 & 0.150 & 0.15 & 0.162 & 0.160 & 0.203 & 0.200 \\
\hline $\mathrm{MoO}_{3}$ & 0.003 & & 0.004 & & 0.004 & & 0.005 & \\
\hline $\mathrm{Na}_{2} \mathrm{O}$ & 9.402 & 9.32 & 11.152 & 11.1 & 11.902 & 11.8 & 14.403 & 14.1 \\
\hline $\mathrm{NiO}$ & 0.014 & & 0.017 & & 0.018 & & 0.023 & \\
\hline $\mathrm{P}_{2} \mathrm{O}_{5}$ & 0.119 & 0.166 & 0.146 & 0.196 & 0.158 & 0.207 & 0.198 & 0.243 \\
\hline $\mathrm{PbO}$ & 0.036 & & 0.044 & & 0.048 & & 0.060 & \\
\hline $\mathrm{RuO}_{2}$ & 0.002 & & 0.002 & & 0.002 & & 0.003 & \\
\hline $\mathrm{SO}_{3}$ & 0.683 & 0.694 & 0.842 & 0.914 & 0.910 & 1.01 & 1.138 & 1.35 \\
\hline $\mathrm{SiO}_{2}$ & 56.678 & 56.3 & 54.344 & 52.4 & 53.344 & 52.4 & 50.010 & 49.9 \\
\hline $\mathrm{V}_{2} \mathrm{O}_{5}$ & 4.159 & 3.77 & 3.990 & 3.57 & 3.918 & 3.57 & 3.678 & 3.25 \\
\hline $\mathrm{ZnO}$ & 0.002 & & 0.002 & & 0.002 & & 0.003 & \\
\hline $\mathrm{ZrO}_{2}$ & 2.076 & 2.01 & 1.990 & 1.92 & 1.954 & 1.90 & 1.833 & 1.82 \\
\hline $\mathrm{Cl}$ & 0.131 & & 0.161 & & 0.174 & & 0.218 & \\
\hline $\mathrm{F}$ & 0.110 & & 0.135 & & 0.146 & & 0.183 & \\
\hline Total & 100.00 & 97.8 & 100.00 & 96.3 & 100.00 & 97.3 & 100.00 & 97.1 \\
\hline
\end{tabular}




\begin{tabular}{|c|c|c|c|c|c|c|c|c|}
\hline \multirow[b]{2}{*}{$\begin{array}{c}\text { WL (mass \%) } \\
\text { Oxide }\end{array}$} & \multicolumn{8}{|c|}{$\bar{C}_{\text {SBW-25 }}{ }^{(\mathbf{a})}$} \\
\hline & \begin{tabular}{|c|}
15 \\
Target
\end{tabular} & Meas. & \begin{tabular}{|c|}
18.5 \\
Target
\end{tabular} & Meas. & \begin{tabular}{|c|}
20 \\
Target
\end{tabular} & Meas. & \begin{tabular}{|c|}
25 \\
Target
\end{tabular} & Meas. \\
\hline $\mathrm{Al}_{2} \mathrm{O}_{3}$ & 4.128 & 4.18 & 5.091 & 5.16 & 5.504 & 5.59 & 6.880 & 6.86 \\
\hline $\mathrm{B}_{2} \mathrm{O}_{3}$ & 10.380 & 10.1 & 9.967 & 9.59 & 9.790 & 9.66 & 9.200 & 9.11 \\
\hline $\mathrm{BaO}$ & 0.002 & & 0.002 & & 0.002 & & 0.003 & \\
\hline $\mathrm{CaO}$ & 4.590 & 4.94 & 4.489 & 4.73 & 4.446 & 4.84 & 4.303 & 4.73 \\
\hline $\mathrm{CdO}$ & 0.012 & & 0.015 & & 0.016 & & 0.020 & \\
\hline $\mathrm{Cr}_{2} \mathrm{O}_{3}$ & 0.032 & 0.031 & 0.039 & 0.053 & 0.042 & 0.142 & 0.053 & 0.067 \\
\hline $\mathrm{CuO}$ & 0.008 & 0.027 & 0.009 & & 0.010 & & 0.013 & \\
\hline $\mathrm{Fe}_{2} \mathrm{O}_{3}$ & 10.412 & 10.3 & 10.041 & 9.98 & 9.882 & 10.0 & 9.353 & 9.78 \\
\hline $\mathrm{Gd}_{2} \mathrm{O}_{3}$ & 0.005 & & 0.006 & & 0.006 & & 0.008 & \\
\hline $\mathrm{K}_{2} \mathrm{O}$ & 1.130 & 1.12 & 1.393 & 1.45 & 1.506 & 1.45 & 1.883 & 1.84 \\
\hline $\mathrm{Li}_{2} \mathrm{O}$ & 2.924 & 2.95 & 2.804 & 2.77 & 2.752 & 2.75 & 2.580 & 2.58 \\
\hline $\mathrm{MgO}$ & 1.546 & 1.55 & 1.498 & 1.50 & 1.478 & 1.49 & 1.410 & 1.44 \\
\hline $\mathrm{MnO}$ & 0.122 & 0.12 & 0.150 & 0.15 & 0.162 & 0.16 & 0.203 & 0.206 \\
\hline $\mathrm{MoO}_{3}$ & 0.003 & & 0.004 & & 0.004 & & 0.005 & \\
\hline $\mathrm{Na}_{2} \mathrm{O}$ & 7.787 & 7.60 & 9.603 & 9.52 & 10.382 & 10.6 & 12.978 & 12.4 \\
\hline $\mathrm{NiO}$ & 0.014 & 0.014 & 0.017 & 0.027 & 0.018 & 0.020 & 0.023 & 0.024 \\
\hline $\mathrm{P}_{2} \mathrm{O}_{5}$ & 0.119 & 0.168 & 0.146 & 0.189 & 0.158 & 0.210 & 0.198 & 0.245 \\
\hline $\mathrm{PbO}$ & 0.036 & 0.035 & 0.044 & 0.072 & 0.048 & 0.048 & 0.060 & 0.063 \\
\hline $\mathrm{RuO}_{2}$ & 0.002 & & 0.002 & & 0.002 & & 0.003 & \\
\hline $\mathrm{SO}_{3}$ & 0.683 & 0.654 & 0.842 & 0.734 & 0.910 & 0.734 & 1.138 & 1.084 \\
\hline $\mathrm{SiO}_{2}$ & 49.572 & 48.6 & 47.531 & 45.8 & 46.656 & 42.4 & 43.740 & 45.6 \\
\hline $\mathrm{V}_{2} \mathrm{O}_{5}$ & 4.159 & 3.81 & 3.990 & 3.57 & 3.918 & 3.59 & 3.678 & 3.40 \\
\hline $\mathrm{ZnO}$ & 0.002 & & 0.002 & & 0.002 & & 0.003 & \\
\hline $\mathrm{ZrO}_{2}$ & 2.076 & 2.01 & 1.990 & 1.90 & 1.954 & 2.00 & 1.833 & 1.78 \\
\hline $\mathrm{Cl}$ & 0.131 & & 0.161 & & 0.174 & & 0.218 & \\
\hline $\mathrm{F}$ & 0.110 & & 0.135 & & 0.146 & & 0.183 & \\
\hline Total & 100.00 & 97.8 & 100.00 & 96.9 & 100.00 & 95.3 & 100.00 & 100.6 \\
\hline
\end{tabular}




\begin{tabular}{|c|c|c|c|c|c|c|c|c|}
\hline \multirow[b]{2}{*}{$\begin{array}{c}\text { WL }(\operatorname{mass} \%) \\
\text { Oxide }\end{array}$} & \multicolumn{4}{|c|}{ SBW-26 } & \multicolumn{4}{|c|}{ SBW-27 } \\
\hline & \begin{tabular}{|c|}
18.5 \\
Target
\end{tabular} & Meas. & \begin{tabular}{|c|}
25 \\
Target
\end{tabular} & Meas. & \begin{tabular}{|c|}
18.5 \\
Target
\end{tabular} & Meas. & \begin{tabular}{|c|}
25 \\
Target
\end{tabular} & Meas. \\
\hline $\mathrm{Al}_{2} \mathrm{O}_{3}$ & 5.091 & 5.31 & 6.880 & 7.16 & 5.091 & 5.41 & 6.880 & 7.18 \\
\hline $\mathrm{B}_{2} \mathrm{O}_{3}$ & 4.979 & 5.07 & 4.610 & 4.64 & 4.979 & 4.78 & 4.610 & 4.68 \\
\hline $\mathrm{BaO}$ & 0.002 & & 0.003 & & 0.002 & & 0.003 & \\
\hline $\mathrm{CaO}$ & 11.963 & 12.07 & 11.180 & 11.8 & 9.974 & 10.8 & 9.350 & 9.87 \\
\hline $\mathrm{CdO}$ & 0.015 & & 0.020 & & 0.015 & & 0.020 & \\
\hline $\mathrm{Cr}_{2} \mathrm{O}_{3}$ & 0.039 & 0.028 & 0.053 & 0.043 & 0.039 & 0.045 & 0.053 & 0.062 \\
\hline $\mathrm{CuO}$ & 0.009 & & 0.013 & & 0.009 & & 0.013 & \\
\hline $\mathrm{Fe}_{2} \mathrm{O}_{3}$ & 1.500 & 1.50 & 1.493 & 1.47 & 1.500 & 1.52 & 1.493 & 1.45 \\
\hline $\mathrm{Gd}_{2} \mathrm{O}_{3}$ & 0.006 & & 0.008 & & 0.006 & & 0.008 & \\
\hline $\mathrm{K}_{2} \mathrm{O}$ & 1.393 & 1.29 & 1.883 & 1.84 & 1.393 & 1.30 & 1.883 & 1.85 \\
\hline $\mathrm{Li}_{2} \mathrm{O}$ & 2.869 & 2.67 & 2.640 & 2.29 & 3.325 & 3.08 & 3.060 & 2.84 \\
\hline $\mathrm{MgO}$ & 1.498 & 1.55 & 1.410 & 1.45 & 1.498 & 1.58 & 1.410 & 1.45 \\
\hline $\mathrm{MnO}$ & 0.150 & 0.145 & 0.203 & 0.185 & 0.150 & 0.140 & 0.203 & 0.181 \\
\hline $\mathrm{MoO}_{3}$ & 0.004 & & 0.005 & & 0.004 & & 0.005 & \\
\hline $\mathrm{Na}_{2} \mathrm{O}$ & 11.152 & 11.0 & 14.403 & 14.0 & 11.152 & 11.2 & 14.403 & 14.2 \\
\hline $\mathrm{NiO}$ & 0.017 & & 0.023 & & 0.017 & & 0.023 & \\
\hline $\mathrm{P}_{2} \mathrm{O}_{5}$ & 0.146 & & 0.198 & & 0.146 & & 0.198 & \\
\hline $\mathrm{PbO}$ & 0.044 & 0.040 & 0.060 & 0.056 & 0.044 & 0.047 & 0.060 & 0.054 \\
\hline $\mathrm{RuO}_{2}$ & 0.002 & & 0.003 & & 0.002 & & 0.003 & \\
\hline $\mathrm{SO}_{3}$ & 0.842 & 0.754 & 1.138 & 1.08 & 0.842 & 0.782 & 1.138 & 1.05 \\
\hline $\mathrm{SiO}_{2}$ & 51.973 & 53.1 & 47.828 & 48.4 & 51.516 & 53.0 & 47.408 & 48.1 \\
\hline $\mathrm{V}_{2} \mathrm{O}_{5}$ & 3.990 & 4.01 & 3.678 & 3.65 & 5.979 & 6.10 & 5.508 & 5.43 \\
\hline $\mathrm{ZnO}$ & 0.002 & & 0.003 & & 0.002 & & 0.003 & \\
\hline $\mathrm{ZrO}_{2}$ & 1.990 & 1.86 & 1.833 & 1.71 & 1.990 & 1.88 & 1.833 & 1.69 \\
\hline $\mathrm{Cl}$ & 0.161 & & 0.218 & & 0.161 & & 0.218 & \\
\hline $\bar{F}$ & 0.135 & & 0.183 & & 0.135 & & 0.183 & \\
\hline Total & 100.00 & 101.0 & 100.00 & 99.0 & 100.00 & 101 & 100.00 & 100.0 \\
\hline
\end{tabular}




\section{Appendix B}

\section{Visual Observations of SBW Glasses}




\section{Appendix B: Visual Observations of SBW Glasses}

\begin{tabular}{|c|c|c|c|c|}
\hline Glass & $\overline{\mathbf{W L}}$ & 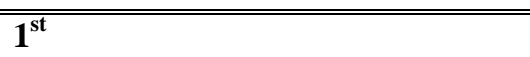 & $\mathbf{2}^{\text {nd }}$ & CCC HT \\
\hline \multirow[t]{2}{*}{ SBW-11 } & 18.5 & $\begin{array}{l}\text { Clean, medium brown glass, } \\
\text { transparent }\end{array}$ & $\begin{array}{l}\text { Clean, medium brown glass, } \\
\text { transparent }\end{array}$ & Clean \\
\hline & 30 & $\begin{array}{l}\text { Clean, medium brown glass, } \\
\text { transparent }\end{array}$ & $\begin{array}{l}\text { Clean, medium brown glass, } \\
\text { transparent }\end{array}$ & Clean \\
\hline SBW-12 & 18.5 & $\begin{array}{l}\text { Clean, medium brown glass, } \\
\text { transparent }\end{array}$ & $\begin{array}{l}\text { Clean, medium brown glass, } \\
\text { transparent }\end{array}$ & Clean \\
\hline SBW-13 & 18.5 & $\begin{array}{l}\text { Light green, transparent, a few pits } \\
\text { on surface }\end{array}$ & $\begin{array}{l}\text { Clean, light/medium green } \\
\text { glass, transparent }\end{array}$ & Clean \\
\hline SBW-14 & 18.5 & $\begin{array}{l}\text { Clean, medium brown glass, } \\
\text { transparent, possible undissolved } \\
\text { material }\end{array}$ & $\begin{array}{l}\text { Patty primarily clean, two } \\
\text { light brown swirls on surface }\end{array}$ & Clean \\
\hline SBW-15 & 18.5 & $\begin{array}{l}\text { Clean, medium brown glass, } \\
\text { transparent }\end{array}$ & $\begin{array}{l}\text { Clean, medium/dark brown } \\
\text { glass, transparent }\end{array}$ & Clean \\
\hline SBW-16 & 18.5 & $\begin{array}{l}\text { Clean, purplish/brown glass, } \\
\text { transparent }\end{array}$ & $\begin{array}{l}\text { Clean, purplish/brown glass, } \\
\text { transparent }\end{array}$ & Clean \\
\hline SBW-17 & 18.5 & $\begin{array}{l}\text { Film across pour patty surface, } \\
\text { yellow spots on bottom of pour } \\
\text { patty, salt ring on crucible wall } \\
\text { above melt line, poured relatively } \\
\text { slow }\end{array}$ & $\begin{array}{l}\text { Dark brown, transparent } \\
\text { glass, no salt observed }\end{array}$ & Clean \\
\hline SBW-18 & 18.5 & $\begin{array}{l}\text { Film across pour patty surface, } \\
\text { yellow spots on bottom of pour } \\
\text { patty, salt ring on crucible wall } \\
\text { above melt line, poured relatively } \\
\text { slow }\end{array}$ & $\begin{array}{l}\text { Dark brown, transparent } \\
\text { glass, no salt observed }\end{array}$ & Clean \\
\hline SBW-19 & 18.5 & $\begin{array}{l}\text { Film across top and bottom of pour } \\
\text { patty surfaces, salt layer observed } \\
\text { on crucible wall above melt line, } \\
\text { poured relatively slow }\end{array}$ & $\begin{array}{l}\text { Dark brown, transparent } \\
\text { glass, no salt observed }\end{array}$ & Clean \\
\hline SBW-20 & 18.5 & $\begin{array}{l}\text { Film across most of pour patty } \\
\text { surfaces (top and bottom), salt } \\
\text { observed on crucible walls above } \\
\text { melt line, poured relatively slow }\end{array}$ & $\begin{array}{l}\text { Dark brown, transparent } \\
\text { glass, no salt observed }\end{array}$ & Clean \\
\hline SBW-21 & 18.5 & $\begin{array}{l}\text { Film across top surface of pour } \\
\text { patty, bottom of pour patty approx } \\
1 / 2 \text { covered, salt observed on crucible } \\
\text { wall above melt line, poured } \\
\text { relatively slow }\end{array}$ & $\begin{array}{l}\text { Dark brown, transparent } \\
\text { glass, no salt observed }\end{array}$ & Clean \\
\hline \multirow[t]{5}{*}{ SBW-22 } & 18.5 & $\begin{array}{l}\text { Clean, light brown, transparent, a } \\
\text { few swirls in bulk glass }\end{array}$ & $\begin{array}{l}\text { Clean, light brown (perhaps } \\
\text { green tint), transparent glass }\end{array}$ & $\begin{array}{l}\text { Transparent, } 2-3 \\
\text { swirls in bulk glass }\end{array}$ \\
\hline & 15 & Clean, light green, transparent glass & Clean & Clean \\
\hline & 20 & Clean, light green, transparent glass & Clean & Clean \\
\hline & 25 & $\begin{array}{l}\text { Clean, medium brown, transparent } \\
\text { glass }\end{array}$ & Clean & Clean \\
\hline & 15 & $\begin{array}{l}\text { Light green/brown glass, } \\
\text { transparent, } 2-3 \text { light brown swirls }\end{array}$ & $\begin{array}{l}\text { Medium green color, } \\
\text { transparent, clean }\end{array}$ & $\begin{array}{l}\text { Light green glass, } \\
\text { transparent, a few }\end{array}$ \\
\hline
\end{tabular}




\begin{tabular}{|c|c|c|c|c|}
\hline "Glass & "WL & $\mathbf{1}^{\mathrm{st}}$ & $2^{\text {nd }}$ & 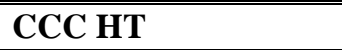 \\
\hline & & possible in bulk & & swirls in bulk glass \\
\hline & 18.5 & $\begin{array}{l}\text { Light green/brown glass, } \\
\text { transparent, a few swirls in bulk - } \\
\text { consistent with previous melt }\end{array}$ & $\begin{array}{l}\text { Medium green color, } \\
\text { transparent, a few dark brown } \\
\text { streaks in bulk glass }\end{array}$ & $\begin{array}{l}\text { Light green glass, } \\
\text { transparent, a few } \\
\text { swirls in bulk glass } \\
\end{array}$ \\
\hline & 20 & $\begin{array}{l}\text { Light brown, transparent, a few } \\
\text { brown swirls }\end{array}$ & $\begin{array}{l}\text { Medium green glass, } \\
\text { transparent, light brown } \\
\text { swirls in bulk glass }\end{array}$ & $\begin{array}{l}\text { Medium green glass, } \\
\text { transparent, a few } \\
\text { swirls in bulk glass }\end{array}$ \\
\hline & 25 & $\begin{array}{l}\text { Medium brown glass, transparent, } \\
\text { swirls in bulk, a few spots (islands) } \\
\text { of dull / film on surface, salt film } \\
\text { observed above melt line on } \\
\text { crucible walls }\end{array}$ & $\begin{array}{l}\text { Dark brown glass, shiny, no } \\
\text { visible signs of salt in patty } \\
\text { or residual crucible glass }\end{array}$ & $\begin{array}{l}\text { Dark brown shiny } \\
\text { glass, swirls in bulk }\end{array}$ \\
\hline \multirow[t]{4}{*}{ SBW-23 } & 18.5 & $\begin{array}{l}\text { Clean, medium brown glass, } \\
\text { transparent }\end{array}$ & $\begin{array}{l}\text { Clean, medium brown/green } \\
\text { glass, transparent }\end{array}$ & $\begin{array}{l}\text { Transparent, } 2-3 \\
\text { swirls in bulk glass }\end{array}$ \\
\hline & 15 & Clean & Clean & Clean \\
\hline & 20 & Clean & Clean & Clean \\
\hline & 25 & Clean & Clean & Clean \\
\hline SBW-24 & 18.5 & $\begin{array}{l}\text { Light brown, film covered both the } \\
\text { pour patty surface and } 1 / 2 \text { of the } \\
\text { bottom, salt observed above melt } \\
\text { line on crucible wall }\end{array}$ & $\begin{array}{l}\text { Clean, medium brown, } \\
\text { transparent glass, residual } \\
\text { crucible glass had a few } \\
\text { brown streaks }\end{array}$ & $\begin{array}{l}\text { Transparent, } 2-3 \\
\text { swirls in bulk glass }\end{array}$ \\
\hline \multirow[t]{4}{*}{ SBW-25 } & 18.5 & Clean, dark brown glass & $\begin{array}{l}\text { Clean, dark brown, shiny } \\
\text { glass, a few pits on surface } \\
\text { possible indicating a high } \\
\text { viscosity }\end{array}$ & $\begin{array}{l}\text { Dark brown, glass, } \\
\text { appears clean, no swirls } \\
\text { or crystallization }\end{array}$ \\
\hline & 15 & Clean & Clean & Clean \\
\hline & 20 & Clean & Clean & Clean \\
\hline & 25 & Clean & Clean & Clean \\
\hline \multirow[t]{2}{*}{ SBW-26 } & 18.5 & $\begin{array}{l}\text { Medium brown glass, transparent, a } \\
\text { few darker brown swirls in bulk }\end{array}$ & Clean & Clean \\
\hline & 25 & $\begin{array}{l}\text { Dark brown glass, semi-transparent, } \\
\text { film observed across surface of pour } \\
\text { patty, salt observed above melt line }\end{array}$ & Clean & Clean \\
\hline \multirow[t]{2}{*}{ SBW-27 } & 18.5 & $\begin{array}{l}\text { Medium brown glass, transparent, a } \\
\text { few swirls in bulk }\end{array}$ & Clean & Clean \\
\hline & 25 & $\begin{array}{l}\text { Dark brown glass, semi-transparent, } \\
\text { film covered portion of surface, salt } \\
\text { observed above melt line }\end{array}$ & Clean & Clean \\
\hline
\end{tabular}


Appendix C

\section{Viscosity Raw Data}




\section{Appendix C: Viscosity Raw Data}

(Viscosity data presented in Poise; to convert to Pa-s divide by 10)

\begin{tabular}{|c|c|c|c|c|c|c|c|}
\hline \multicolumn{2}{|c|}{ 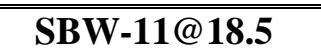 } & \multicolumn{2}{|c|}{ "SBW-15@18.5 } & & & & \\
\hline $\begin{array}{l}\text { Temp } \\
\left({ }^{\circ} \mathrm{C}\right)\end{array}$ & $\begin{array}{c}\text { Viscosity } \\
\text { (P) }\end{array}$ & $\begin{array}{c}\text { Temp } \\
\left({ }^{\circ} \mathrm{C}\right)\end{array}$ & $\begin{array}{c}\text { Viscosity } \\
\text { (P) }\end{array}$ & & & & \\
\hline 1150 & 39.20 & 1158.5 & 28.73 & & & & \\
\hline 1095.5 & 57.76 & 1090 & 46.86 & & & & \\
\hline 1043 & 87.05 & 1050 & 63.15 & & & & \\
\hline 1150.5 & 38.80 & 1151 & 30.3 & & & & \\
\hline 1206 & 26.04 & 1203.5 & 21.14 & & & & \\
\hline 1151.1 & 38.99 & 1153 & 30.38 & & & & \\
\hline \multicolumn{2}{|c|}{ SBW-17@18.5 } & \multicolumn{2}{|c|}{ SBW-20@18.5 } & \multicolumn{2}{|c|}{ SBW-21@18.5 } & & \\
\hline $\begin{array}{l}\text { Temp } \\
\left({ }^{\circ} \mathrm{C}\right)\end{array}$ & $\begin{array}{c}\text { Viscosity } \\
\text { (P) }\end{array}$ & $\begin{array}{c}\text { Temp } \\
\left({ }^{\circ} \mathrm{C}\right)\end{array}$ & $\begin{array}{c}\text { Viscosity } \\
\text { (P) }\end{array}$ & $\begin{array}{l}\text { Temp } \\
\left({ }^{\circ} \mathbf{C}\right)\end{array}$ & $\begin{array}{c}\text { Viscosity } \\
\text { (P) }\end{array}$ & & \\
\hline 1150 & 163.92 & 1154.5 & 53.52 & 1148.5 & 69.86 & & \\
\hline 1089 & 255.15 & 1100.5 & 84.35 & 1090 & 114.77 & & \\
\hline 1046 & 373.96 & 1046 & 124.76 & 1052.5 & 139.43 & & \\
\hline 1147 & 158.39 & 1150.5 & 55.19 & 1147 & 69.5 & & \\
\hline 1199.5 & 105.22 & 1201 & 37.5 & 1201 & 46.3 & & \\
\hline 1150 & 157.2 & 1150 & 55.79 & 1152 & 67.49 & & \\
\hline \multicolumn{2}{|c|}{ SBW-22@15 } & \multicolumn{2}{|c|}{ SBW-22@18.5 } & \multicolumn{2}{|c|}{ "SBW-22@20 } & \multicolumn{2}{|c|}{ SBW-22@25 } \\
\hline $\begin{array}{c}\text { Temp } \\
\left({ }^{\circ} \mathrm{C}\right)\end{array}$ & $\begin{array}{c}\text { Viscosity } \\
\text { (P) }\end{array}$ & $\begin{array}{c}\text { Temp } \\
\left({ }^{\circ} \mathrm{C}\right)\end{array}$ & $\begin{array}{c}\text { Viscosity } \\
\text { (P) }\end{array}$ & $\begin{array}{c}\text { Temp } \\
\left({ }^{\circ} \mathrm{C}\right)\end{array}$ & $\begin{array}{c}\text { Viscosity } \\
\text { (P) }\end{array}$ & $\begin{array}{c}\text { Temp } \\
\left({ }^{\circ} \mathrm{C}\right)\end{array}$ & $\begin{array}{c}\text { Viscosity } \\
\text { (P) }\end{array}$ \\
\hline 1150 & 82.55 & 1151.5 & 67.11 & 1154 & 62.01 & 1145.5 & 53.03 \\
\hline 1094.5 & 133.66 & 1098.5 & 106.81 & 1098 & 100.98 & 1091.5 & 83.95 \\
\hline 1048 & 211.84 & 1050 & 170.74 & 1052 & 157.24 & 1044.5 & 131.53 \\
\hline 1152 & 80.02 & 1152 & 67.19 & 1151.5 & 64.14 & 1151 & 51.03 \\
\hline 1200.5 & 54.14 & 1201 & 45.33 & 1207 & 41.45 & 1201 & 34.7 \\
\hline 1151 & 81.04 & 1150 & 68.23 & 1150 & 65.17 & 1150 & 52.04 \\
\hline \multicolumn{2}{|c|}{ SBW-23@18.5 } & & & & & & \\
\hline $\begin{array}{c}\text { Temp } \\
\left({ }^{\circ} \mathbf{C}\right)\end{array}$ & $\begin{array}{c}\text { Viscosity } \\
\text { (P) }\end{array}$ & & & & & & \\
\hline 1150 & 56.38 & & & & & & \\
\hline 1099 & 86.22 & & & & & & \\
\hline 1043 & 137.90 & & & & & & \\
\hline 1149.5 & 56.20 & & & & & & \\
\hline 1204 & 37.45 & & & & & & \\
\hline 1151 & 56.56 & & & & & & \\
\hline
\end{tabular}




\begin{tabular}{|c|c|c|c|c|c|c|c|}
\hline \multicolumn{2}{|c|}{ SBW-25@15 } & \multicolumn{2}{|c|}{ 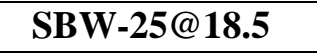 } & \multicolumn{2}{|c|}{ SBW-25@20 } & \multicolumn{2}{|c|}{ SBW-25@25 } \\
\hline $\begin{array}{c}\text { Temp } \\
\left({ }^{\circ} \mathrm{C}\right)\end{array}$ & $\begin{array}{c}\text { Viscosity } \\
\text { (P) }\end{array}$ & $\begin{array}{c}\text { Temp } \\
\left({ }^{\circ} \mathrm{C}\right)\end{array}$ & \begin{tabular}{|c} 
Viscosity \\
(P)
\end{tabular} & $\begin{array}{l}\text { Temp } \\
\left({ }^{\circ} \mathrm{C}\right)\end{array}$ & $\begin{array}{c}\text { Viscosity } \\
\text { (P) }\end{array}$ & $\begin{array}{c}\text { Temp } \\
\left({ }^{\circ} \mathrm{C}\right)\end{array}$ & $\begin{array}{c}\text { Viscosity } \\
\text { (P) }\end{array}$ \\
\hline 1153.5 & 76.12 & 1145 & 65.21 & 1151.1 & 55.96 & 1150.5 & 42.06 \\
\hline 1098.5 & 130.01 & 1094.5 & 105.07 & 1094.5 & 93.45 & 1097 & 63.99 \\
\hline 1051.5 & 209.08 & 1045.5 & 173.41 & 1043.5 & 154.89 & 1037 & 109.18 \\
\hline 1151 & 78.08 & 1150 & 62.9 & 1150 & 56.78 & 1152 & 42.62 \\
\hline 1202.5 & 51.48 & 1207 & 39.33 & 1216 & 34.96 & 1208 & 27.46 \\
\hline 1152.5 & 77.93 & 1151.5 & 62.07 & & & 1149.5 & 44.15 \\
\hline \multicolumn{2}{|c|}{ SBW-26@18.5 } & \multicolumn{2}{|c|}{ SBW-27@18.5 } & & & & \\
\hline $\begin{array}{c}\text { Temp } \\
\left({ }^{\circ} \mathrm{C}\right)\end{array}$ & $\begin{array}{c}\text { Viscosity } \\
\text { (P) }\end{array}$ & $\begin{array}{c}\text { Temp } \\
\left({ }^{\circ} \mathrm{C}\right)\end{array}$ & \begin{tabular}{|c} 
Viscosity \\
(P)
\end{tabular} & & & & \\
\hline 1149.5 & 65.78 & 1151 & 63.86 & & & & \\
\hline 1082 & 128.04 & 1096 & 105.61 & & & & \\
\hline 1047.5 & 187.38 & 1047.5 & 170.5 & & & & \\
\hline 1151 & 65.05 & 1149 & 62.73 & & & & \\
\hline 1202.5 & 42.60 & 1200 & 41.09 & & & & \\
\hline 1150 & 65.07 & 1148 & 63.55 & & & & \\
\hline
\end{tabular}


PNNL-14050

\section{Distribution}

No. of

Copies

OFFSITE

1 Catholic University of America

Vitreous State Laboratory

620 Michigan Ave., N. E.

Washington, D. C. 20064, Attn:

I. L. Pegg

Hannon Hall

1 U. S. Department of Energy

Office of Science and Technology (EM-54)

19901 Germantown Rd., 2087/Cloverleaf Bldg

Germantown, MD 20874-1207, Attn:

Kurt Gerdes

16 Westinghouse Savannah River Company

Aiken, South Carolina 29808, Attn:

D. F. Bickford

999-W

A. D. Cozzi

999-W

T. B. Edwards

773-42A

J. C. George

C. C. Herman

E. W. Holtzscheiter

T. L. Lorier

S. L. Marra

D. K. Peeler (5)

I. A. Reamer

D. C. Witt

R. J. Workman

999-W

773-42A

773-A

999-W

999-W

999-W

773-A

999-W

999-W

4 Bechtel BWXT Idaho, Inc. (BBWI)

PO Box 1625 Idaho Falls, ID 83415, Attn:
A. L. Olson
K. J. Perry
L. Lauerhass
B. A. Scholes

MS 5218

MS 5218

MS 5218

MS 5218
No. of

Copies

\section{ONSITE}

1 DOE/Office of River Protection

R. Carreon

H6-60

1 DOE/Richland Operations Office

T. E. Pietrok

$\mathrm{K} 8-50$

3 Washington Group

J. M. Perez

$\mathrm{H} 4-02$

E. V. Morrey

$\mathrm{H} 4-02$

C. A. Musick

H4-02

1 CH2M Hill Hanford Group

K. A. Gasper

L4-07

26 Pacific Northwest National Laboratory

W. F. Bonner

K9-14

T. M. Brouns

K9-69

R. A. Brouns

K9-64

W. C. Cosby

K7-62

J. V. Crum

K6-24

R. W. Goles

K6-24

P. R. Hrma

K6-24

L. K. Holton

H6-61

D. S. Kim

K6-24

D. E. Kurath

P7-28

L. M. Peurrung

K6-24

M. J. Schweiger

K6-24

H. D. Smith

K6-24

J. D. Vienna (10)

K6-24

B. J. Williams -- TFA

K9-69

Technical Report Files (2)

P8-55 